University of Louisville ThinkIR: The University of Louisville's Institutional Repository

Electronic Theses and Dissertations

$5-2019$

\title{
Vile transgressor of the womb : prosecution and persecution for concealment in Puritan Massachusetts.
}

Jennifer White

University of Louisville

Follow this and additional works at: https://ir.library.louisville.edu/etd

Part of the Women's Studies Commons

\section{Recommended Citation}

White, Jennifer, "Vile transgressor of the womb : prosecution and persecution for concealment in Puritan Massachusetts." (2019). Electronic Theses and Dissertations. Paper 3142.

https://doi.org/10.18297/etd/3142

This Doctoral Dissertation is brought to you for free and open access by ThinkIR: The University of Louisville's Institutional Repository. It has been accepted for inclusion in Electronic Theses and Dissertations by an authorized administrator of ThinkIR: The University of Louisville's Institutional Repository. This title appears here courtesy of the author, who has retained all other copyrights. For more information, please contact thinkir@louisville.edu. 
VILE TRANSGRESSOR OF THE WOMB:

\title{
PROSECUTION AND PERSECUTION FOR CONCEALMENT
}

IN PURITAN MASSACHUSETTS

\author{
By \\ Jennifer White \\ B.A., SUNY Potsdam, 2004 \\ M.A., University of Louisville, 2010

\begin{abstract}
A Dissertation
Submitted to the Faculty of the

College of Arts and Sciences of the University of Louisville in Partial Fulfillment of the Requirements

for the Degree of
\end{abstract} \\ Doctor of Philosophy \\ In Humanities \\ Department of Comparative Humanities \\ University of Louisville \\ Louisville, Kentucky
}

May 2019 

VILE TRANSGRESSOR OF THE WOMB:

\title{
PROSECUTION AND PERSECUTION FOR CONCEALMENT
}

IN PURITAN MASSACHUSETTS

\author{
By \\ Jennifer White \\ B.A., SUNY Potsdam, 2004 \\ M.A., University of Louisville, 2010 \\ A Dissertation Approved on
}

December 3, 2018

by the following Dissertation Committee

\begin{tabular}{c}
\hline $\begin{array}{c}\text { Dissertation Director } \\
\text { Nancy M. Theriot }\end{array}$ \\
\hline Karen M. Chandler \\
\hline Susan M. Ryan
\end{tabular}

Dale B. Billingsley 


\section{DEDICATION}

For Rebekah Chamblit.

September 27, 1733 


\section{ACKNOWLEDGEMENTS}

I would like to thank Dr. Nancy Theriot, Dr. Karen Chandler, and Dr. Susan Ryan who have been with me from the beginning when this dissertation was a small, archival project. You three have given so much of your time and you have continuously challenged me to do my best work. I am forever grateful to you all. I would also like to thank Dr. Dale Billingsley for agreeing to be my outside reader and for his invaluable feedback. I am grateful to the Comparative Humanities staff and faculty for the outstanding program we have. I am fortunate to have found a home here among so many great people.

I want to recognize Dr. Anne Malone who encouraged me to pursue a career in academics. Her generous spirit lives on in the many undergraduates she inspired. I want to thank Jane for showing me how to repair a broken foundation, and how to bury Porter paint cans. You showed me how to mend my own soul.

A sincere thank you to Julie Kroger and Sandy Garcia who read every single word I wrote, even the ones that didn't make it into this dissertation. I could not have started or finished without your support and encouragement. You provided advice when I didn't want to hear it; you provided patience when I was short-tempered; you provided love when I was low; and you provided margaritas.

And finally, thank you to my husband and my boys for enduring so many nights of grilled cheese and quesadillas. 


\section{ABSTRACT \\ VILE TRANSGRESSOR OF THE WOMB: \\ PROSECUTION AND PERSECUTION FOR CONCEALMENT \\ IN PURITAN MASSACHUSETTS \\ Jennifer White}

December 3, 2018

This dissertation investigates the crime of concealment in Puritan Massachusetts. The 1624 Jacobean statute, which specifically identified concealing as both the crime and the evidence, provided the basis for prosecuting women who concealed the death of an infant. This dissertation focuses on an analysis that connects the act of concealment to a larger discussion of a woman's association with secrecy and hiding that led to labeling her postpartum, criminal body as a threat to the colony. The act of concealment was evidence of a woman's ability to control her own reproduction and her unwillingness to acknowledge her calling in Puritan Massachusetts: motherhood.

This dissertation begins with a historical examination of the Massachusetts Bay colony to argue that, because of their covenant, illicit sexual misconduct and concealment caused a rift between the body of the colony and God's favor. Their use of the 1624 statute for concealment and use of the Old Testament precepts were manifestations of their desire to form a legal system that enforced the values of the Puritan community 
specific to Massachusetts Bay. Chapter one also investigates anxieties concerning captivity, war, revocation of their charter, and declension of the Massachusetts Bay colony to contextualize the tense atmosphere surrounding the Puritan leadership that underscores the development of the Puritan jeremiad as an execution sermon for concealment. Chapter two traces the use of religious texts as instruments of literacy as well as for spiritual and emotional sustenance. Investigating the community's belief in the power of printed material in a wilderness, both physical and spiritual, foregrounds the discussion about the role of the intimate connection between reading and spiritual life as they formed their Congregational Church.

In Puritan Massachusetts women were exceptionally vulnerable in cases of immorality and sexual transgression, even more so when the sexual transgression resulted in a pregnancy. This vulnerability coupled with subjective criminality created a precarious situation for young, unmarried women. Chapter three analyzes Thomas Foxcroft's sermon and Rebekah Chamblit's declaration to show the rhetorical function of these texts. Chapter four argues these texts labeled Rebekah's postpartum body a threat because of her ability to conceal evidence of her sexual sin and denied her calling to motherhood: a tenet of a virtuous woman in Puritan Massachusetts. 


\section{TABLE OF CONTENTS}

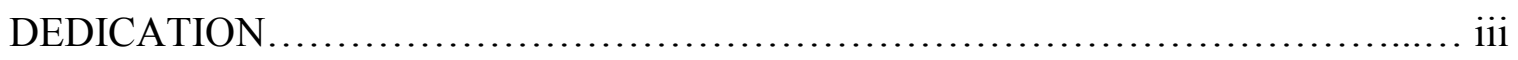

ACKNOWLEDGEMENTS.................................................. iv

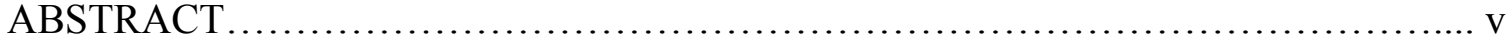

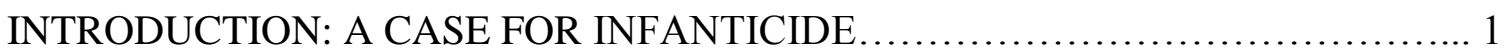

CHAPTER ONE............................................................ 22

Historicizing Infanticide in Early America:

A Colony of Anxious Puritans

CHAPTER TWO.......................................................... 70

Literacy, Print Culture, and Ministerial Discourse:

Jeremiads in Early America

CHAPTER THREE ....................................................... 107

Sexualizing Crime:

Concealment in Massachusetts Bay

CHAPTER FOUR.

Foul Transgressor of the Womb:

The Disavowal of the Infanticidal Body and Concealer of Sin

CONCLUSION

The Puritan Infanticidal Pregnancy

REFERENCES.

CURRICULUM VITAE. 
INTRODUCTION

\section{A CASE FOR INFANTICIDE}

"While lying there no beast did tear

which seems to testify,

For blood conceal'd must be reveal'd

it did for vengence cry."

A brief Relation of Murder committed by Elizabeth Shaw,

Who was executed at Windham, on the $18^{\text {th }}$ of

Nov. 1744, for the Murder of her Child.

Elizabeth Shaw was only one of numerous women remembered for the murder of

their infant in early America. However, their convictions resulted not from proof of

murder: their crime was concealment. In the New England colonies of early America, the discovery of a hidden infant corpse would have warranted prosecution of the mother for concealment, not murder, regardless of the circumstances of the death. Referred to as infanticide, the shocking discovery of a dead infant was nothing new to the Puritans who landed on the shores of the New World. In fact, infanticide was prosecuted in early America under the existing English statute of 1624, An Act to Prevent the Destroying and Murthering of Bastard Children:

WHEREAS, many lewd women that have been delivered of bastard children, to avoid shame, and to escape punishment, do secretly bury or conceal the death of their children, and after, if the child be found dead, the said woman do alledge, that the said child was born dead; whereas it falleth out sometimes (although 
hardly it to be proved) that the said child or children were murthered by the said women, their lewd mothers, or by their assent or procurement:

II. For the preventing therefore of this great mischief, be it enacted by the authority of this present parliament, That if any woman after one month next ensuing the end of this session of parliament be delivered of any issue of her body, male or female, which being born alive, should by the laws of either by herself or the procuring of others, so to conceal the death thereof, as that it may not come to light, whether it were born alive or not, but be concealed: in every such case the said mother so offending shall suffer death as in case of murther, except such mother can make proof but one witness at the least, that the child (whose death was by her was so intended to be concealed) was born dead. (qtd. in Hoffer and Hull 20)

The statute, 21 James I, c. 27, did not define a new law; murder was murder regardless of the victim. Instead, the statute made concealment $^{1}$ of the death of a child a capital crime. Yet the language within the statute is even more telling than the creation of the statute.

The establishment of the English colonies began with the issuance of the 1629 Massachusetts Bay Charter and the 1630 Great Migration of Puritans. For the next 10 years 20,000 disgruntled Puritans would land on the shores of New England in order to escape the Church of England's reach. Upset by the church's corruption and the capricious judicial system of England, settlers of the Puritan colonies were given the opportunity to establish a new system of justice, a system they hoped would stave off the

\footnotetext{
${ }^{1}$ I use the italicized version of concealment to differentiate between the act of concealment versus the crime of concealment throughout this dissertation. This is particularly useful when discussing the Puritan attitude for concealing to position the statute for concealment as particularly offensive.
} 
growing social disorder and lax moralities. In chapter one of this dissertation, I make a case for examining Massachusetts Bay specifically because their charter, the formation of their colonial statutes, their creation of the Congregational Church, and a focus on the Puritan calling make them unique. Historian Edmund Morgan, in The Puritan Dilemma: The Story of John Winthrop (1958), provides a foundation for understanding the complexities of establishing the colony. By examining primary source material by John Winthrop and John Cotton, and the biblical scripture they identify, this dissertation begins by discussing the formation of the colony and how its legal structure differed from those of the Chesapeake colonies before contextualizing the 1624 statute specifically in Massachusetts.

In Puritan Massachusetts women were vulnerable in cases of immorality and sexual transgression, even more so when the sexual transgression resulted in a pregnancy. This vulnerability coupled with subjective criminality created a precarious situation particularly for young, unmarried women. Ministers in Massachusetts Bay capitalized on the cases of women convicted under the 1624 statute by using powerful sermons to present their sins to the community. Indeed, most scholarship focuses on the crime of infanticide as a sexual one and ignores the language of concealment in the statute itself. The statute specifically identifies concealing as both the crime and the evidence. This dissertation contends that the issue of concealment, and its place in the larger Puritan framework, has been overlooked in previous scholarship in favor of the sexual nature of the crime. While other scholars have examined the texts surrounding infanticide, this dissertation seeks to focus attention on an analysis that connects the act of concealment to a larger discussion of a woman's association with secrecy and hiding that led to labeling 
her postpartum, criminal body as a threat to the colony. The act of concealment indicated the woman's ability to control her own reproduction and identifies her unwillingness or failure to acknowledge her calling in Puritan Massachusetts: motherhood.

The 1624 statute was the basis for prosecuting a woman who concealed the death of her infant, born alive or dead, but it also provided the basis for targeting unmarried women for the crime. For the first time, the moral standing of a woman, through the use of the term lewd, is at issue and is connected to the term bastard. ${ }^{2}$ Until 1624, infant murder was tried as murder. This dissertation investigates the development of the statute in England as a response to an increase in the number of infant murders prior to 1624 . While the statute was used to prosecute women on both sides of the Atlantic, English historian Mark Jackson, in Infanticide: Historical Perspectives on Child Murder and Concealment, 1550-2000 (2002) provides the research for England's prosecution of infanticide as compared to the prosecutions in Massachusetts provided by legal historians Peter C. Hoffer and N.E.H. Hull, in Murdering Mothers: Infanticide in England and New England, 1558-1803 (1981). I argue that the development of the 1624 statute in England is uniquely different from its application in Puritan Massachusetts. After 1624, the courts could issue a guilty verdict based on concealment and the moral status of the woman accused, which this dissertation argues, was particularly useful for addressing the Puritan preoccupation with concealing sin. The purpose of this comparison is to provide a means of understanding the rationales behind the criminalization of a woman who concealed the death of an infant child in England and a woman in New England who concealed not only

\footnotetext{
${ }^{2}$ Peter C. Hoffer and N.E.H. Hull trace the issue of morality in Elizabethan legal texts and find no issue with the moral status of a woman as the central argument to the case of infanticide except in a legal note where the use of the word harlot is used to describe a woman who hid an infant corpse in 1593 (8-10).
} 
the death but was assumed to be concealing her sexual sin as well. Even though the language of the statute described the crime as concealment of death, and practicality suggests it is easier to hide an infant than a child, the statute was not limited to infants. Infanticide in England could refer to children as old as nine years of age (Hoffer and Hull 18). While there is a wealth of existing statistical data to account for the age of the victims prosecuted under the 1624 statute, my dissertation defines and uses the term infanticide to mean neonatacide: infant corpses that appear to have lived no more than a few hours. Though many of the statistics available do not specify between the ages of the victims, this dissertation focuses exclusively on cases where the infant or infants were concealed at birth in the discussion of concealment in Massachusetts.

Sermons and narratives provide first-hand accounts of some of the most notorious events of the time. Whereas murder convictions require proof of culpability, in the case of infanticide, a woman is proved guilty of concealment and the presumption of murder follows. Preliminary archival research leads us to believe the woman was convicted of murdering her child but her crime, under the 1624 statute, was concealment. Though titles and subtitles of sermons and execution narratives focus on the term murder, symbolic language alluding to concealment is also used. This is the case of Elizabeth Shaw, for example, who is remembered not through court records but through the verses written about her execution: "For blood conceal'd must be reveal'd." The same is true of many cases buried in the archives for the crime of concealment. This observation leads to the question of why concealment warranted a capital punishment in lieu of a murder charge. The obvious response to such a question would be that murder is the more heinous of the two and the texts exist merely to create sensationalism around the crime. 
While this response is valid, the question still warrants an investigation into the events that produced these archival materials to examine both the crime and the language used to produces these Puritan texts.

In order to show how these texts functioned, this dissertation explores the language used in the sermon and declaration for the conviction of Rebekah Chamblit, in 1733 , for concealment. To accomplish that, this dissertation first investigates the production of that language by a community educated to believe the minister's speech as literally God's word. Execution sermons were rooted in scripture and criminal historian Bradley Chapin, in Criminal Justice in Colonial America, 1606-1660 (1984), remarks on the Puritan belief that the magistrate himself was God's deputy and how the Puritan colonists empowered them as such. While governors of the Chesapeake colonies answered to an earthly authority, Puritan magistrates answered to the ultimate authority, God. Given that Puritan thought was influenced by sixteenth-century theologian John Calvin, who explicitly described magistrates as God's "deputies" who were asked to do God's bidding on earth, discretionary justice was expected and accepted (17-19). In order to maintain the clarity and the focus on Puritan communities, this dissertation uses Chapin's categorization of Puritan versus Chesapeake colonies ${ }^{3}$ and focuses on Rebekah's case in Puritan Massachusetts.

Chapter one revisits some of the unique characteristics in the formation of the Massachusetts Bay colony through an analysis of several notable historians-Perry Miller, Edmund S. Morgan, Emory Elliott, and John Demos. The goal is to create a context for understanding the generational divide between Puritan ministers and to offer a more

\footnotetext{
${ }^{3}$ Chapin qualifies the Puritan colonies as Plymouth, Massachusetts, Connecticut, and New Haven, and his rationale is explained later in this dissertation.
} 
comprehensive understanding of their tense beginnings, their concerns for the stability of their colony, and their anxiety for the future of their covenant. Historian Edmund Morgan reconstructs the challenges to colonial government that Winthrop faced and Perry Miller describes the challenges Winthrop faced in the formation of the Congregation Church. Declining church membership, Antinomians, and Arminians are discussed in chapter one to help our contemporary minds understand the tense strain felt by each generation of Puritan ministers in Massachusetts Bay in order to frame the way the leadership handled challenges and perceived threats to their authority and to their covenant.

Understanding the power in the pulpit and that power's connection to the community is essential to understanding the power behind the implementation of the 1624 statute and the language, both spoken and written, created by Puritan ministers. Chapter two explores the issue of literacy in Massachusetts. Because a major element of the reformation was the accessibility of God's word, every Puritan household was charged with the education of their youth so that they could read the Bible ${ }^{4}$. This emphasis fused together literacy and religion for the new generation of Puritans so that printed texts achieved power and permanence within the community. David D. Hall, in Worlds of Wonder, Days of Judgment: Popular Religious Belief in Early New England (1989), and John Demos, in A Little Commonwealth: Family Life in Plymouth Colony (1989), help create a framework for understanding how literacy was intimately tied to the use of religious texts and the authority Puritans placed in printed material. Tracing the use of religious texts as instruments of literacy, as intimate connections between reading

\footnotetext{
${ }^{4}$ While Puritans preferred the Geneva Bible over the King James Bible, I use the King James for reference purposes because the language is similar to that of the Geneva yet also a vernacular contemporary readers are familiar with.
} 
and spiritual life, and as God's word, my dissertation argues that the minister was able to extend the church's influence beyond the pulpit through the creation of the uniquely American jeremiad and the domination of colonial print culture. Chapter two provides the foundation for understanding the power of the language used in the literature published in conjunction with a public execution for the crime of infanticide.

Other research questions I investigate in this dissertation involve the connection between the importance of language within the Puritan Massachusetts community and the use of postpartum language. To do this, chapter two also analyzes the development and the use of the jeremiad sermon. Notable historian Perry Miller, in The New England Mind: From Colony to Province (1967), traces the history of the Puritan jeremiad, drawn from the biblical prophet Jeremiah who claimed that all the adversities and tragedies of the time were caused by the broken covenant with God. Originally used as sermons for days of humiliation, Miller argues that the content of these public sermons, and the drama they produced, shift from internal reflection to external accusation of others as the first and second generation of Puritan ministers struggled with the changes in their colony. Ministers used these sermons as a means for issuing a collective atonement for transgressions resulting in a fracturing of their covenant. Recent work by Andrew R. Murphy, in Prodigal Nation (2006), argues that this form of sermon exists in other societies, but the jeremiad is linked to a "larger, sacred story tied intimately to the particularities of the nation's origin and development" giving birth to the uniquely American invention (10). This dissertation explores the development and function of the jeremiad in colonial New England to understand how these sermons become tools for 
specifically addressing women for the crime of concealment and for using her postpartum body as the metaphorical and physical site of concealed sin.

Capitalizing on this effect of permanence through print, chapter two shows how Puritan ministers were able to extend their influence into the everyday lives of the community. Just as church and state were interdependent, so were the church and community. Execution sermons, more than other sermons, reached a wider audience because of the sensationalism built around the public nature of the execution itself. The fact that a large majority of published sermons were occasioned by an infanticide conviction suggests infanticide may have served a greater purpose in Puritan New England. Daniel Cohen, in Pillars of Salt, Monuments of Grace: New England Crime Literature and the Origins of Popular Culture:1674-1860 (1993), traces the development of print culture of and its relationship to popular culture. From 1674 to 1860, pamphlets, books, and broadsides relating to capital crimes and containing sermons and execution narratives were prolifically printed (ix). In the early years of public execution Puritan ministers appointed themselves solely responsible for acquiring, writing, overseeing the publishing, and occasionally even the distribution of execution texts. Yet it wasn't the ministers' education that made their writings so popular; it was their successes in the pulpit. According to Hall, the Puritan ministers' plain speaking and minimal use of doctrinal language were well received by the average colonist (Worlds of Wonder 56). "[Yet] the ways they viewed the world were sustained by print culture ..." arguing that ministers, through print mediums, were able to reinforce their sermons with the average lay person (Hall 70). Undoubtedly, it was the occasion for the sermon that also contributed to its popularity. Execution sermons and narratives were an ideal form of 
family reading (Cohen 5) and would have had the greatest impact on the community because of their permanency when printed.

Working together with declarations, sermons concerning infanticide were instructive, accusatory, and meant to evoke fear from the congregation and contempt for the convicted (Williams, "Pillars" 5; Cohen 84). Prior to 1800, 203 pieces of gallows literature were published in the Americas: 71 execution sermons and 121 pieces of supplementary material, including narratives (written with second-hand information) and "confessions" or "dying words" from the criminals themselves. Execution sermons were also the most popular form of crime literature through the first decades of eighteenthcentury Puritan New England (Bosco "Checklist" 82). ${ }^{5}$ Understanding their importance is preparation for examining the question: what kind of language do ministers use to addresses the criminal of an infanticide sermon if her crime is concealment and not murder?

Chapter three analyzes the language of the statute itself which enabled ministers to distribute justice unequally between men and women because the statute gendered the crime of concealment. This analysis starts with scholarship by legal historians N.E.H. Hull, in Female Felons: Women and Serious Crime in Colonial Massachusetts (1987), and Cornelia Dayton Hughes, in Women Before the Bar: Gender, Law, and Society in Connecticut, 1639-1789 (1995), to begin a discussion of female felons that helps contextualize female crime in Puritan New England. The early Puritans created their own system of criminality and punishment in the colonies, a system that went unquestioned by the body politic and allowed for the high rate of conviction against unmarried women.

\footnotetext{
${ }^{5}$ The missing numbers reference 11 gallows poems.
} 
Women were frequently targets of a double standard in not only the application of laws but in the nature of crimes themselves ${ }^{6}$ and the 1624 statute made infanticide a female crime. What seems to be an obvious inequality to the modern audience may not have been so easily discerned by the Puritan community. The statute required only the evidence of concealment to support the presumption of murder. The goal of chapter three is to focus on Foxcroft's jeremiad to analyze the language that I argue created a connection between the woman on the gallows and the perceived threat to their covenant. This dissertation connects a woman's precarious position in the Puritan community to this statute through her connection to an untrustworthy and inherently evil nature to support the conviction of a woman by both the court and the community. Similarly, John Demos, in Entertaining Satan: Witchcraft and the Culture of Early New England (2004), discusses how the culpability of those charged with witchcraft no longer matters to a community that believes in the reality of witchcraft. "What does matter is that many of them were believed guilty, and that this belief was itself efficacious" (9). So, too, is the very nature of the infanticide statute and a woman's connection to sin.

Chapter three also examines the symbolic language involving secrecy, hiding, and sin used in one example of crime literature to suggest that a woman convicted of concealment posed a particular threat to the leaders of the Puritan colony. While it can be argued that the language of concealment was the very essence of defining the crime, there is evidence to suggest that the act of concealing was something more to the Puritan community, especially when it came to the law. To accomplish this, chapter three provides a discussion of concealment based on Peter Charles Hoffer's findings, in

\footnotetext{
${ }^{6}$ Hughes studies the gendered patterns of litigation and prosecution in Connecticut, one of the colonies established as Puritan.
} 
"Principled Discretion: Concealment, Conscience, and Chancellors." Hoffer examines the use of chancellors' discretion in judicial proceedings in early America. Chapter three deconstructs Hoffer's research to argue that we can infer from the judges' attitudes over concealment of the condition of material goods by plaintiffs that the crime of concealment, because of the inherent secrecy in its construction and its execution, would also be seen as reprehensible because female sexual behavior was constructed as secret and hidden. The case of Rebekah Chamblit is introduced in chapter three and an analysis of Thomas Foxcroft's execution sermon, Lessons of Caution to Young Sinners, finds the use of language denoting secrecy and hiding that targets Rebekah's crime and sin. Using the evidence found in Foxcroft's sermon, this dissertation argues that the decentralized jeremiad warrants a new understanding of its function in the gallows drama.

Most scholars focus exclusively on either the sermons or the narratives produced within the genre of crime literature. Recent scholars offer new investigations of infanticide accounts. Kathleen M. Brown's article, “Murderous Uncleanness: The Body of the Female Infanticide in Puritan New England" (2001), examines a sermon delivered by Cotton Mather at the execution of Elizabeth Emerson for infanticide, and Jodi Schorb, in "Hard-Hearted Women: Sentiment and the Scaffold" (2011), raises several questions about how gender and sentimentality change the way women are reflected in infanticide narratives. Brown discusses Cotton Mather's use of the term unclean in his sermon delivered at the execution of Emerson. Contemporary Puritan attitudes on uncleanness and filth-avoidance practices produced the most potent rhetoric used to define moral cleanliness. Brown argues that the female is an object of uncleanness using examples of Mather's use of metaphors for filth and self-pollution in association with the unclean 
when sermonizing about Emerson. This dissertation builds on Brown's scholarship regarding the language used in the sermons but focuses instead on the use of metaphorical language related to secrecy and hiding in addition to motherhood and the postpartum body rather than that of the unclean. These metaphors appear in the sermon delivered by Thomas Foxcroft at the execution of Rebekah Chamblit. The language used by Foxcroft identifies Rebekah's body as the source of the unclean but he also draws attention to Rebekah's secret behavior and her postpartum body.

While Brown takes on the sermon, Schorb considers the narrative. Her core argument is concerned with the way the sermons and the narratives relate to the gallows crowd: “'executions' gendered power shapes its power affects, its ability to reproduce an affective response in the condemned and in those watching his or her execution" (291). Her work is essential to chapter three of this dissertation because it lays a foundation for arguing the value of considering how the texts can function in opposition to the gallows crowd by not producing an affective response. Brown and Schorb also discuss how these texts functioned within the community to identify the body of the criminal as a site of uncleanness and sexual knowledge. This dissertation seeks evidence of the language of motherhood to add to the growing scholarship involving early American infanticide and to connect the function of biblical language and metaphor as a familiar commodity in the Puritan community. The entire dramatic process of the infanticide phenomenon-sermon in church, printed sermon and narrative in the hands of the crowd, and the gallows scene - reveals the importance of language in Puritan Massachusetts. The current scholarship passes over the status of the woman as a postpartum body in favor of discussing infanticide as a sexual crime. If the gallows is indeed a drama, the appearance 
of a woman in her postpartum state cannot be ignored as a possible reason for the popularity of infanticide cases as both crime literature and public spectacle.

Meredith Marie Neuman, in Jeremiah's Scribes: Creating Sermon Literature in Puritan New England (2013), discusses the difficulties facing modern scholars dealing with the production of sermons in early America. Beyond not reading like a seventeenthcentury colonist and not generally being the faithful Calvinist of that period, Neuman questions why a faithful people, who believed that the Bible was a perfect book that held all one needed for salvation, produced so many other works for the purpose of sermonizing? Neuman argues that the sermon contributes to the complicated scholarship of Puritanism but must be examined to understand any of the literature produced in the period. While Neuman challenges the authorship of many of the notable sermons produced in the seventeenth and eighteenth centuries, she argues that sermon culture is important to understanding the language produced in both the sermon itself but also to all elements of literature. Neuman's scholarship is phenomenological in nature because her interest is in the experience of sermon culture as a means of understanding the literature. Essential to my own research is Neuman's conclusions about the lived experience of hearing these texts at the gallows in conjunction with the sight of a postpartum female convicted of concealment.

Perhaps even more important to infanticide cases is the issue of symbolic language in the sermons and narratives because of its connection to the visual. Undoubtedly, execution sermons and narratives made for fantastic reading and contributed to the garish display of the gallows drama. Richard Lazenby's essay, "Exhortation as Exorcism: Cotton Mather's Sermon to Murderers" (1971), describes the 
gallows spectacle: "as a drama written, directed, produced, and prompted by God," (50). Hall discusses the permanency of symbolic language by saying, "The archetypal source was Scripture. Its figures, tropes, and stories were echoed and reechoed in almost every kind of text that people came in contact with ... It even overrode the gap that may have separated readers and nonreaders, because it lent itself to visual presentation" (Hall 69). Through the publication of these sermons, infanticidal women were represented by Puritan ministers as sexual beings who posed a threat to the community. The visual image of the woman on the gallows allows the community to witness her body as a vessel of sexual knowledge and her postpartum state as proof of her sin and her crime.

Puritan women convicted of concealment were subject to the exigency of their connection to the body and the widely-accepted ideology of women as innately sexually sinful. Jodi Schorb, in "Uncleanliness is Next to Godliness: Sexuality, Salvation, and the Early American Women's Execution Narrative" (2001), discusses the gallows crowd's expectations: "Unlike other crimes ... infanticide sexualizes the woman's body (mostly young, mostly unmarried) as a site of sexual knowledge" (73). While a woman's actual sexual activity is not evident in other crimes, a woman convicted of concealing the death of her infant, literally, delivered the proof of her sexual sin. The mere fact that the woman on the gallows was sexually experienced, as evidenced by her postpartum body, sent her plummeting to the category of whore. Richard Godbeer, Sexual Revolution in Early America (2002), plumbs the history of sex and Puritan sex attitudes to find that sexual norms were formed and enforced by the colonial founders. Beyond denouncing illicit sexual activity as "unclean," Puritan church officials were intent on reversing the social acceptance of premarital sex that was so common in England (9). "Early Americans 
worried about sex because they believed that it embodied, literally, their identity and worth, individually and collectively" (10-11). As mentioned before, Brown deconstructs Cotton Mather's use of the term unclean in his sermon delivered at the execution of Emerson, a term encompassing all elements of sexual wrongdoing. Yet given that current scholarship argues that the body of the woman convicted of infanticide is labeled a site of sexual knowledge, her status as a postpartum body also warrants an investigation.

Kelly Ryan, in Regulating Passion: Sexuality and Patriarchal Rule in Massachusetts, 1700-1830 (2014), examines the connections between patriarchal rule and sexuality especially where sexuality intersects with race, class, and gender. Ryan argues that sexual regulation was a cornerstone for maintaining control by the hierarchy of Massachusetts. While changes were occurring in the eighteenth century, such as rising premarital sex rates, Ryan argues that Massachusetts strengthened its efforts to stem these changes. While the patriarchy is her focus, Ryan also investigates the ways that wealthy white women began to challenge the double standard that allowed men to participate in illicit sexual acts without damage to their reputations. Direct regulation of sexual behavior gave way to a "culture of virtue to enforce patriarchal sexual ethics through societal norms" during the eighteenth and nineteenth centuries (4). My research investigates the crime of concealment as evidence of enforcing sexual ethics rather than direct regulation of sexual activity. Ryan notes that marriage was a means of subordinating white women. In chapter four of my dissertation, I take up the argument that a woman who was convicted of concealment can also be viewed as a woman who had denied her calling to motherhood, a tenet of a virtuous woman in Puritan 
Massachusetts. Thomas Foxcroft's sermon written for the execution of Rebekah Chamblit reveals her violation of this culture of virtue.

Chapter four offers an historical approach to religiosity by several scholars to suggest the origin of these ideas. Elizabeth Reis, in Damned Women: Sinners and Witches in Puritan New England (1997), examines the witch trials to reveal that women were judged and condemned based on "religiously founded notions of their nature and proper sphere" and suggests that women were believed to have sinful natures while men had natural sins (12). John D'Emilio and Estelle Freedman, authors of Intimate Matters: A History of Sexuality in America (1997), suggest that the polemics against sin reveal a gendered narrative in colonial New England. While men were more often associated with public disturbances — violence or drunkenness — women "bore the brunt of private transgressions" (5). These private transgressions often turned sexual conduct by men into something uniquely different than transgressions committed by women. Lyle Koehler, in A Search for Power: The "Weaker Sex" in Seventeenth-Century New England (1980), discusses how women faced even greater pressure than men to suppress sexual desire because "if a woman happened to engage in uncleanness, it would leave an indelible imprint upon her character ... she could, with one act of intercourse, be transformed from an admirable virgin to a despicable whore or slut." Koehler contrasts the position of women with men by pointing out that the woman is corrupted and ruined while the man simply committed folly (74). These gendered expectations are infused in the very fabric of the early Puritan. Religious scholar Mary Ann Stenger, in "Feminist Philosophy of Religion" (2002), suggests that "male" and "female" categories are used in social-cultural norms of behavior and defined by patriarchy, and we are socialized at birth to understand 
these differentiations (150-151). My research explores these differentiations of the female character represented in the sermons and narratives as the cultural evidence used to convict women of concealment.

Puritan attitudes of uncleanness and filth-avoidance practices produced the most potent rhetoric used to define moral cleanliness. Mather evokes the metaphor of filth and self-pollution in association with the unclean, thus solidifying Brown's argument that the female infanticide is an object of uncleanness. Executions of female criminals, she notes, "allowed ministers to minimize the abstraction in the metaphor of the unclean body and to explain graphically the danger sinners posed to the Puritan social body" (Brown 82). Similarly, chapter four deconstructs the language used by Foxcroft that identifies Rebekah's body as the source of the unclean and his creation of metaphors that draw particular attention to Rebekah's sexual sin and her postpartum body, as well as her crime. Chapter four also investigates the references of "mother" and "womb" in Foxcroft's sermon and Rebekah's declaration to argue that these labels also apply to the body of the woman on the gallows. These labels also enable him to draw attention to the postpartum body of Rebekah. Evidence of such language warrants the following research questions: Does the traditional jeremiad function differently to comment on her failed motherhood and is this a remark on her unwillingness to play her role? Is there a connection between the term concealment and its use in other Puritan contexts that reflect an attitude of fraudulent behavior? Is the woman convicted of concealment defrauding the community of something?

While infanticide has been argued by other scholars as a sexual crime, and there is language in the sermon and declaration to support this, the use of maternal language is 
evidence of something too. The potency of infanticide texts, metaphorical and symbolic language so familiar to the community, was reinforced by the visual image of the woman on the gallows. Chapter four examines these rhetorical devices used in the gallows drama of Rebekah Chamblit to better understand how they are mutually reinforcing the ministers' message and question the effect the language of secrecy and hiding and of her postpartum state has in the gallows drama. After an examination of the scripture choices by Foxcroft, this final chapter discusses the effect his decentralized jeremiad has in tandem with Rebekah's declaration.

Narratives, declarations, or "dying speeches" were even more popular than the sermons or the hangings, and had the ability, in print, to leave a more lasting impression on the readers who were asked to read the printed material carefully. Some execution sermons were published beforehand, but at the very least these the declarations were produced by ministers in collaboration with the criminals in time to be published and distributed to the gallows crowd. The ministers delivered the woman's declaration, and "In his delivery, he dramatically pretended to be speaking for the felon to the audience or to God, uttering a warning or prayer [with] the tone of a prophet or God himself" (54). The entire gallows venture was staged for the greatest effect and resulted in the gallows crowd's active participation in the felon's chastisement. The publication of execution sermons and narratives combined with the visual image of the death of the sinner gave the minister's message an enduring impression. This research asks how does the entire gallows drama function if we read Foxcroft's sermon as targeting Rebekah's postpartum body? 
Chapter four argues that the postpartum body changes the traditional jeremiad and connects the body of the woman on the gallows to the role of women as mothers and illuminates her crime as a violation of her expected role. If the sermon evokes language relating to motherhood, then that language is therefore reiterated by the sight of her postpartum body on the gallows. Foxcroft uses the language of motherhood and childbirth to illuminate the fact that Rebekah has not only murdered her infant but that she is also no longer a mother. This language has the power to destabilize the jeremiad's intended effect on the gallows crowd, to create a "window to the soul." My dissertation demonstrates how the language of secrecy and hiding within the statute and the sermon function to connect women to their sinful natures, which was used as evidence against her and served to change the affective response of the community.

The ultimate goal of this research is to create a space for examining the importance of language to the Puritan community as a foundation for understanding the relevance of the law, Foxcroft's sermon, and Rebekah's declaration. Only by positioning the rhetorical value and the function of these infanticide texts within the context of the community can we hope to understand the experience of women in early America. Beginning with the statute that created the gendered crime of concealment, my research examines how language reflects and is reflected in the community's attitude toward women through an analysis of the symbiotic nature between the sermon and the declaration used in Rebekah Chamblit's case. The language effectively destabilizes the traditional jeremiad's goal of addressing the sin as the colony's guilt and creates instead a jeremiad that encourages Rebekah's disavowal from the community. This research attempts to show how a woman's epic connection to sin and evil is manifested in 
Rebekah's postpartum body by the anxious Puritan community's predilection to connect a woman to willful and fraudulent behavior as evidence for the crime of concealment and as evidence of her refusal to acknowledge her calling that helped maintain the covenant promised by the body politic of Massachusetts. 


\author{
CHAPTER ONE \\ HISTORICIZING INFANTICIDE \\ IN A COLONY OF ANXIOUS PURITANS \\ Moreover I will appoint a place for my people Israel, \\ and I will plant them, \\ that they may dwell in a place of their own, \\ and move no more. \\ II Samuel 7:10
}

The formal establishment of the English colonies as a refuge for religious dissenters began with the issuance of the 1629 Massachusetts Bay Charter. Prior to that, colonial settlements, such as Sir Walter Raleigh's settlement at Roanoke, William Bradford's governance of Plymouth, and Roger Conant's relocation from Cape Anne to Naumkeag to establish what would become Salem, were the products of venture capitalism, pilgrimage, and separatism. But for the 10 years following the 1629 Bay Charter, twenty thousand disgruntled Puritans landed on the shores of New England in order to escape the Church of England's reach.

Unlike Separatists, Puritans held on to the hope that England would reform itself in God's image and return to the righteous path. Yet, concern over the possibility of England's redemption grew after the succession of Charles I in 1625. John Winthrop, who would become the first governor of Massachusetts Bay, expressed his growing concern for the pending wrath of God in a letter to his wife Margaret, dated May 15, 1629. 
The Lorde hath admonished, threatened, corrected, \& astonished us. Yet we growe worse \& worse, so as his Spirit will not allwayes strive with us, he must needs give waye to his furye at last: He hath smitten all the other Churches before our eyes, \& hath made them to drinke of the bitter cuppe of tribulation, even unto death. We sawe this, \& humbled not ourselves, to turne from our evill ways, but having provoked him more than all the nations rounde about us therefore he is turning the Cuppe towards us also, $\&$ because we are the last, our portion must be, to drinke the verye dregs which remain: My dear wife, I am verily persuaded, God will bringe some heavye Affliction upon this lande, \& speedylye. (qtd. in Life and Letters of John Winthrop 296)

Winthrop's fear of "the verye dregs" offered to him and his brethren because they "humbled not ourselves" was a very real threat to the heart of Winthrop's Puritanism. One of the tenets of Puritanism was the belief that nations "existed by virtue of a covenant with God, an agreement whereby they promised to abide by His laws, and He in turn agreed to treat them well” (Morgan, The Puritan Dilemma 19). For Puritans, a government's first and foremost responsibility was to enforce God's laws and to punish infractions to remain in God's favor and avert any punishment from Him. Puritans were able to hold on to their belief in a just and righteous nation when that government acted according to the covenant. Winthrop expressed to his wife what others had already expressed about the future of England.

It was a rollercoaster ride of faith for English Puritans in the sixteenth and seventeenth centuries. Following years of persecution, the death of the staunch Catholic Queen Mary in 1558 allowed Puritans to enjoy a tenuous revival of faith during the 
reigns of Elizabeth I and James I. Though Elizabeth was neither for nor against the Puritans, she did appoint a few Puritan advisors. The elevation of these close confidants, and the appointment of an Archbishop with Puritan sympathies by James I, led Puritans to view Parliament as a resource for keeping England in God's favor. But the ascension of Charles I to the throne in 1625, and his marriage to a Catholic, complicated the perceived threat felt by the Puritans. Charles' appointment of several professed Arminians, men labeled heretics by the Puritans, to significant positions within the church and state augmented the Puritan fear of God's wrath. When Charles dissolved Parliament in 1629 his action broke the spirit of many Puritans (Morgan, The Puritan Dilemma 26-27). But to leave England was Separatist-thinking, and Winthrop, when presented with the chance to join the Massachusetts Bay Company for emigration to the colonies, debated with himself and others about the merits and consequences of removing to New England and abandoning England. Evidence suggests that Winthrop likely began his list of reasons titled "Reasons to be considered for justifieinge the undertakers of the intended Plantation in New England, \& for incouraginge such whose hartes God shall move to joyne with them in it" as early as May 1629. This and the subsequent "Diverse objections which have been made against this Plantation, with their answers \& Resolutions" reflect his long struggle with the decisions to leave. ${ }^{7}$

In the end, Winthrop and his friends decided that, unlike the charters and companies that went before them, the Massachusetts Bay Company would not be a

\footnotetext{
${ }^{7}$ Winthrop, Life and Letters of John Winthrop 1588-1630, 308-319, summarizes the arguments made by other scholars in regards to the authorship of these lists but concludes that the lists were part of the papers of John Winthrop himself and in the handwriting of his son, Forth Winthrop, who was known to be in the employ of his father as a copyist. See also Heimert, Alan, and Andrew Delbanco, eds. Puritans in America: A Narrative Anthology (1985): 39-40.
} 
commercial enterprise and would be instead a colony of refuge for the recruitment of godly people. A colonial charter simply defined the area of the land that the company had dominion over and this group of men had godly plans for their slice of New England. The king and his advisers were likely none the wiser and would have had no reason to suspect the Bay Charter to be unlike any of those issued before it, yet Edmund S. Morgan, in The Puritan Dilemma: The Story of John Winthrop (1958), notes that "through oversight, design, or indifference" the location of the yearly company member meeting was omitted from the charter when signed by the king leaving Winthrop and his clever followers to take advantage of the omission by proposing the meetings take place in the colony itself rather than in London. This was a fortunate twist of fate for Winthrop that gave his colony an autonomy no other had. The company governor could become the governor of the colony, and the company could become the legislative assembly of the colony. Morgan argues the advantages of such a move were obvious to the Puritans, "If the company moved to New England, it could become a self-governing commonwealth, with the charter a blank check justifying everything it did. It would thus be able to enforce the laws of God and win divine favor" (The Puritan Dilemma 46).

This fortuitous oversight provided freedoms that Winthrop and his supporters would later interpret as God's providence. With their blank check in hand, they carved out a space in the wilderness and established a new system of justice. Though the need for reform and for the enforcement of public control into the legal system was felt by all the colonies in New England, the Puritan colony's desire to adhere to Old Testament law distinguished the colonists' intent from the others and the statutes written into Massachusetts Code of Laws were directly accompanied by supporting biblical scripture. 
As expected, certain crimes were pursued more fervently in the Bay Colony than in other colonies and reflect Winthrop's intent for establishing a commonwealth in God's image by repairing the things he and his followers felt had been left ungoverned in England.

The overall goal of this research is to examine the crime of concealment as being a particularly offensive one for these early Puritan followers of Massachusetts Bay. Statistical evidence shows that the overwhelming number of victims in suspected cases between 1690 and 1730 were bastard children, resulting in the prosecution of single women for the crime. Illegitimate children were viewed as problematic in both England and New England, but scholars argue the two regions viewed illegitimacy a problem for different reasons. Sexual misconduct was ferreted out in the parishes of England to prevent the physical and monetary burden of orphans on the community. In the case of Massachusetts, illicit sexual misconduct and concealment of any kind created a rift between the body of the colony and God's favor. This chapter argues that the Puritan colony's use of the 1624 statute for concealment and their use of Old Testament precepts was a manifestation of their desire to form a legal system that enforced the values held by their Puritan community.

To that end, this chapter begins with an effort to recreate the intense anxiety felt by early Puritans for establishing their godly colony. From Winthrop's departure from England to internal and external challenges to church leadership while controlling their fear of the unknowable, the Puritans of Massachusetts faced anxieties at every turn. An accounting of these anxieties help differentiate between Massachusetts Bay and other colonies to contextualize the crime of concealment as a threat to the colony's covenant. "The danger for us, from our vantage point of three centuries later, is that we may fail to 
appreciate the forces of tradition, the old ways and values--and especially the power of religion" (Demos, A Little Commonwealth, 12). This chapter highlights the events that created additional tensions within an already tense Puritan community. How these rising tensions continued to manifest themselves within the colony is taken up later in this dissertation to explain the vehemence for ferreting out crime and sin.

Before investigating the specific crime of concealment, and the implementation of the 1624 English statute, this dissertation will also include a discussion of the evolution of the crime in England before its codification into law in New England. Understanding the progression of the statute helps to contextualize how the distinct characteristics of colonial Puritan life contributed to the difference between the two regions' treatment of the crime. Infanticide, known as concealment, was a particularly heinous crime because Puritan theology treats concealment as evidence of an immoral nature rather than a simple criminal act. In fact, this chapter will argue the implementation of the 1624 statute was particularly useful to the Puritan community because it emphasizes concealment, as the statute directs, rather than the issue of murder. It is impossible to know the intentions of the justice system or the individual temperament of the legislators behind the statute in either region, but, the present purpose is to show the differences between the two regions in order to argue the need for a more discerning approach to concealment in the Massachusetts Puritan community.

While England saw its own increase in the number of infanticide cases, the motivation behind the application of the statute was different than that of the colonies. The crime of concealment, the 1624 statute, An Act to Prevent the Destroying and Murthering of Bastard Children, and its subsequent application in New England, 
therefore, warrants a new interpretation with the possible understanding that the crime was a means of addressing a woman's morally corrupt nature, as evidenced by her concealment of the crime from the colony. In fact, while most scholars suggest that the crime was a way to address a woman's illicit sexual behavior, this research culminates with the suggestion that the discourse surrounding the crime was an advantageous way to discuss the defunct moral character of all women by linking the use of the term concealment as evidence of a larger Puritan tenet. My research does not try to set the New England infanticide cases apart from English cases, nor does it seek to prove that the overall increase in the number of cases is in anyway indicative of the culture of either continent. Rather, the increases in each reflect how the application of the law against concealment was used as a means to overcome the distinct difficulties faced by each region: in England, rising poor rates; in New England, rising morality issues.

\section{Anxious Puritans:}

\section{From Transatlantic Move to the Challenges of Congregationalism}

Despite Winthrop's resolution to leave England, he and his followers were concerned that their actions would be confused with the actions of the Separatists who departed England a decade before on the Mayflower to form Plymouth Plantation. Separatists, unlike Puritans, distanced themselves from the perceived threat of sin and believed with certainty that their own congregations were true believers. A key tenet of the Separatist faith was for members to disavow the Church of England, fearing contamination by the faithless and corrupt. Their purpose in leaving England, first to Holland in the late 1580 s and then to the colonies in 1620 , was to distance themselves from sin and sinners (Heimert and Delbanco 39-40). The Puritans who embarked on the 
Arbella, however, departed without leaving the Church of England or the King. As part of the Puritan faith, believers were to live in the world but be focused always on God. But Winthrop's concern for being confused with the Separatists was not a desire to see himself or his company exalted for their difficulties or successes resulting from their reverence for God, but instead from a desire to receive God's favor for living righteously. ${ }^{8}$ Puritans felt great responsibility for the community's favor with God, and they shaped colonial culture to that purpose, requiring a public life that reflected their religious commitment (Reinitz 1-3).

Winthrop himself was especially worried that the ship's manifest of Puritans would be assumed to be Separatists and took exceptional care to declare their belief that "they were acting in the best interests of those who remained behind, that the pure church they intended to establish in New England would someday, somehow, rescue its English parent from the mire of corruption" (Morgan, The Puritan Dilemma 51). In fact, this enclave of Puritans was likely more concerned with the impression of desertion they were leaving behind than with the wilderness they were headed for. ${ }^{9}$ As the anxiety of their removal from England mounted, Winthrop and his company issued a statement, "The Humble Request of His Majesty's Loyal Subjects, the Governor and Company late gone for New England; and to the rest of their Brethren in and of the Church of England; for the obtaining of their Prayers, and the removal of Suspicions, and Misconstructions of their Intentions," declaring it an honor to be associated with the Church of England. Their humble request, in both words and tone, does not sound like a group trying to distance

\footnotetext{
${ }^{8}$ Morgan discusses the difficulties Winthrop faced on a personal level with his struggle to balance his attention. He was often troubled by his love for his wife and his love for God, The Puritan Dilemma, 10-13. ${ }^{9}$ Morgan, The Puritan Dilemma,51-53, discusses the struggle felt by several other key members of the group.
} 
themselves, as the Separatists of Plymouth would have, from the unworthy: "What we entreat of you that are the ministers of God, that we also crave at the hands of all the rest of our brethren, that they would at no time forget us in their private solicitations at the throne of grace" (“The Humble Request" qtd. at winthropsociety.com). Despite their protestations, the tension still ran high with Winthrop and his company. John Cotton, who would later join Winthrop in Massachusetts Bay, came down to Southampton before the Arbella departed to reassure the company of God's approval in his sermon God's Promise to His Plantations: “...for consolation to them that are planted by God in any place, that find rooting and establishing from God, this is a cause of much encouragement unto you, that what he hath planted he will maintain." (qtd. in Puritans in America 80). Cotton's entire sermon revolves around the metaphor of trees being planted to create a perfect and pleasing plantation. He chooses for his scripture 2 Samuel 7:10 "Moreover, I will Appoint a Place for my people Israel, and I will PLANT them, that they may dwell in a place of their OWN, and MOVE NO MORE" (Cotton, God's Promise 1). Cotton goes on to reaffirm for his audience, what Winthrop's own message tried to establish, that the Arbella was not an attempt to leave England to its own destruction but that England too could continue to prosper; Cotton creates an analogy to God's claiming land for the Israelites:

But here is something more especial in this planting': for they were planted before in this Land, and yet he promiseth here again, that he will plant them in their Own Land: which doth imply;

First, That whatever former good estate they had already, he would prosper it, and increase it. 
Secondly, God said to plant a People more especially, when they become trees of righteousness, Isaiah 61:3. That they may be called trees of righteousness, the planting of the Lord. So that there is implied, not only a continuance of their former good estate; but that he would make them a good people, a choice generation. (14)

Not only did Cotton affirm Winthrop's mission but he also attempted to assuage the anxiety that Winthrop and his group were like rats leaving a sinking ship. As the preeminent clergyman and intellectual of his time (Heimert and Delbanco 75), Cotton's words went a long way to reassure the company, and those remaining in England, of the promise of God.

Winthrop delivered his sermon A Model of Christian Charity onboard the Arbella as an additional platitude. But his sermon was also meant to assemble and focus the minds of the colonists. Though Winthrop was not a minister, it was not uncommon for men to preach "lay" sermons ${ }^{10}$ that were free from the typical rhetorical form and often flowed as more a speech than a sermon. Winthrop reassures the company that they are under a special commission from God and reminds them that they are under obligation to fulfill their covenant: "Thus stand the cause between God and us. We are entered into a covenant with him for his work. We have taken out a commission, the Lord hath given us leave to draw our own articles ... Now if the Lord shall please to hear us, and bring us in peace to the place we desire, then hath he ratified this covenant and sealed our commission, will expect a strict performance of the article contained in it" (reprinted in

\footnotetext{
${ }^{10}$ Heimert and Delbanco note that these types of sermons would be forbidden in the coming years following the expulsion of Anne Hutchinson from the Bay Colony for delivering such sermons, Puritans in America, 81.
} 
Puritans in America 90). While still on the deck of the ship they left England on, because England was failing in their covenant with God, Winthrop's words impressed upon his company their heavy responsibilities. His purpose was also to remind them of the consequences of failure: "But if we shall neglect the observation of these articles which are the ends we have propounded and, dissembling with our God, shall fail to embrace this present world and prosecute our carnal intentions, seeking great things for ourselves and our posterity, the Lord will surely break out in wrath against us, be revenged of such a perjured people, and make us know the price of the breach of such a covenant" (reprinted in Puritans in America 90-91).

Winthrop's words hardly strike fear in our modern consciences. But, for Puritans, who believed that their lives were a covenant with God, the threat of God's wrath was a very physical thing. In his research of daily life in the Plymouth colony, Demos notes that one of the challenges of being a historian is the effort to reconstruct the power of religion for the modern reader, “. . . especially its interior, its reverberations in the thoughts and feelings and behavior of the average believer" (12). Winthrop had a boatload of average believers, common laborers and working families, on his hands and those believers looked to him for spiritual guidance and assurance: a job he took seriously as they headed for a savage wilderness. He reminded them that this was a commission undertaken with God's approval and that He has made it possible for them to leave, and if He gets them through the voyage safely, then they know they are doing His work. In return, they must rejoice together, mourn together, labor and suffer together, and at all times keep their eyes on God: "The Lord will be our God, and delight to dwell among us as his own people, and will command a blessing upon us in all our ways, so that we shall see much 
more of his wisdom, power, goodness, and truth ... We shall find that the God of Israel is among us ..." and Winthrop delivered one of the most famous lines attributed to the Puritan migration, "For we must consider that we shall be as a city upon a hill. The eyes of all people are upon us ... (“A Model of Christian Charity” reprinted in reprinted in Puritans in America 90-91). Rather than a warning or a pronouncement of anxiety, Winthrop was stating what he and his company firmly believed: they were going to do things in honor of God, and they would be an example of hope for their brethren back in England. This was the certitude for their commission these Puritans brought with them to the shores of New England along with their anxieties.

Part of the concern Winthrop felt over his decision to leave England can be attributed to the larger Puritan cosmology: believing religious unity to be essential. Recent scholarship by Abram C. Van Engen, in Sympathetic Puritans: Calvinist Fellow Feeling in Early New England (2015), claims that this unity hinged on brotherly love, a mutual affection for one another, that fortified their belief that consensus could be achieved regardless of differences. Yet, the disaffected could never be reasoned with (9091). This adherence to the belief in consensus also reveals a willingness to compromise. Winthrop stressed unity more than anything in his sermon on the deck: "It is by mutual consent, through a special overvaluing providence and a more than an ordinary approbation of the churches of Christ, to seek out a place of cohabitation and consortship under a due form of government both civil and ecclesiastical" ("A Model of Christian Charity" reprinted in Puritans in America 90-91). These words "government both civil and ecclesiastical" essentially warned of no separation of church and state. And so that everyone was clear, "In such cases as this, the care of the public must oversway all 
private respects" (“A Model of Christian Charity" reprinted in Puritans in America 9091). For Puritans, the elevation of the community over the self was not a revolutionary idea, and anything contrary bordered on separatist leanings.

Even after the Bay Colony was established, separatist thinking was a threat to unity: "The separatist was always ready to disagree with his neighbors and, when they failed to meet his standards, to withdraw into a lofty and querulous independence, accompanied by all whom he could persuade to join him ... Separatists could disintegrate the colony and dissolve its special commission" (Morgan, The Puritan Dilemma 74-75). Puritans were constantly concerned with their own intentions and how those intentions might be perceived. Winthrop needed and expected all hands-on deck for their mission in New England. "For this end, we must be knit together in this work as one man ... always having before our eyes our commission and our community in the work, our community as members of the same body" ("A Model of Christian Charity" reprinted in Puritans in America 90-91). Winthrop's words, Perry Miller explains, in "Errand Into the Wilderness" (1953), regarding public over private were necessary to the successful mission and would be easily achieved "if all gazed only at it and strove only for it, then social solidarity ... would be an automatic consequence. A society dispatched upon an errand that is its own reward would want no other rewards: it could go forth to possess a land without ever becoming possessed by it" (7-8). The colony was considered to be "one" and every effort was made to keep the unity through a rhetoric of community commitment. Failing to keep the community together was a failure on the part of every individual and their own spirituality. Winthrop made it clear that the government he had in mind would be both civil and ecclesiastical and as Miller explains: "What a due form 
of government meant, therefore, became crystal clear: a political regime, possessing power, which would consider its main function to be the setting up, the protecting and preserving of this form ... of being, in short, deliberately, vigorously, and consistently intolerant" (7).

It is important to create a framework for understanding how Winthrop's words forced everyone aboard the Arbella to acknowledge, before they even stepped foot on this promised land God offered, their compliance with their commission and this proposed form of government. These Puritans felt the weight of their world and they were determined to cutout their part of this vast wilderness and be prosperous in their faith at all costs. Thus the Puritan colony of Massachusetts Bay was established. As the years progressed in Massachusetts Bay so did the tense climate for maintaining control over the colony in the face of religious, political, and social challenges in addition to the large influx of immigrants. Anxieties ran high in Massachusetts Bay: anxiety over the extension of power to the newly regenerate by the colony's founders; anxiety over challenges posed against their newly established Congregational Church; anxiety over establishing a process for adding new church members; and the anxiety over threats from their wilderness environment. Their overall approach to handling these challenges was to expose and expel those who could not be controlled, and to extend church membership through the creation of a half-way covenant while limiting those members from sharing the power reserved for the church leadership.

Though Winthrop envisioned a "City on a Hill," Perry Miller argues that the idea of a community being guided by biblical ethics was not what made New England unique. Such a community had been imagined by others; yet, "The sanguine colonials went far 
beyond this elementary stage and dedicated themselves to an even more rigorous program, which they called Congregationalism" (Miller, "The Half-Way Covenant" 677). Congregationalists took the Protestant theology of the elect, those predestined for election to heaven through regeneration and faith, and decided they were able to govern themselves and the members of their church: "that the Word of God was sufficient check upon their portion of human depravity" (Miller, "The Half-Way Covenant" 678) without the need for external governance. Protestant theology removed Catholic church clergy as intercessors of God's Word. For Puritans, the access to God's Word through a common vernacular and literacy meant that faith and attendance to doctrine would be all the regenerate needed to remain the elect. Thus, Congregationalism took both church governance and church membership into its own hands through the explanation of various covenants, primarily the Covenant of Grace. Congregationalism is unique to New England Puritans and it also makes New England unique: "A holy state, received into a covenant with God, differed from an uncovenanted one not because all its citizens were saints but because therein saints could determine and administer the laws and the natural inhabitants be either incited or compelled to obey" (Miller, "Preparation" 255). The Congregational Church they would establish hinged on a belief in covenants in order to ensure unity and obedience to carry out their commission from God.

Leaving behind the altars, clerical leadership, and forming a new church meant that organized worship was open to invention. Not every idea or every person was embraced by the new inventions of Congregationalism. Congregational leadership took it upon themselves to issue membership by personally approving those professing regeneration. There is evidence to suggest that the settlers Mather had targeted for a new 
congregation failed to pass the established system for identifying the regenerate (Hall, The Last American Puritan 20-21; Morgan, Visible Saints 100-101). " "The basic assumption of Congregationalism was that it would be difficult, not to get people into the churches, but to keep them out. Hence only those who could demonstrate a Covenant of Grace would be admitted, and with them their children: these, being baptized, were sealed into the Covenant [of Grace] and therefore, according to the promise of Abraham, would grow up to become saints" (Miller, From Colony 11). The difficulty for New England Puritans would come in proving, to these church leaders, evidence of their election. One's salvation, John von Rohr argues, in “Covenant and Assurance in Early English Puritanism” (1965) was always a precarious thing: “ . . the problem for each individual was one of knowing whether the covenant had been extended to him" (197). The anxiousness felt by Puritans regarding their election was reinforced by notable ministers of the time as well. While John Preston, in his sermon The New Covenant (1629), wrote "If thou believe, it is certaine then, that thou art within the Covenant" but also wrote of the existence of "a false, dead, and counterfeit faith" (qtd. in von Rohr 197). Anxious Puritans facing the uncertainties of the wilderness relied heavily on the comfort of these promises from God. These covenants, the one that brought them to election and the one that brought them to these shores, were promises made with God and by God to his saints. "So the very character of covenant commitment provides the assurance that God will act according to his promise" (von Rohr 196). The promise should have comforted the wary Puritans but there was an inherent tension in just being Puritan.

\footnotetext{
${ }^{11}$ This new system I refer to here is discussed later in this chapter.
} 
One's assurance, even the most notable Puritans of the period, would be challenged by the Congregational leadership in New England.

For the Puritans of Massachusetts, with their newly established colony and newly established church structure, maintaining the unity of the state was a means to guard against challenges to both their power over the colony and challenges to their theology. The Puritan state functioned to govern all of society to maintain order and provide leadership over the entire colonial body not just through the legislation of laws. They dedicated themselves to reforming the behaviors they viewed as challenges to their leadership. Though their intent was clear, threats rose almost immediately.

Puritans knew they were not alone in their colony and that Anabaptists, Arminians, Antinomians, and Separatists mingled among them. Religious tolerance was never part of their design and, in fact, Puritans never balked at cutting off the ears of blasphemers or whipping Quakers (Miller, The Puritans 185). They were unrepentant about the qualifications of being part of their colonial body and dissenters and dissidents could be tolerated only for so long. As a result, rebellious thinkers like Roger Williams and Anne Hutchinson were expelled from the colony for instigating fellow congregants to challenge the leadership. Williams instigated questions among the church members about the authority of civil magistrates to punish for religious beliefs. His comments drew the attention of colonial leaders and his arguments kept him at odds with the deputies and assistants, but his leadership position posed the biggest challenge. As minister of the Salem church, Williams could argue that his removal would be a violation of congregational independence. Church leadership had to tread lightly, and ultimately decided that "The churches may be powerless by the principle of congregational 
independence, but the civil government was not" (Morgan, The Puritan Dilemma 126). The court's concern for the fallout that would come from a complete dismissal of the Salem congregation was valid. "To crush the rebellion of an entire church would have proved a difficult, if not bloody, if not impossible, business. To crush it in the face of any widespread sympathy would certainly have split the colony" (Morgan, The Puritan Dilemma 126). But the ministers and magistrates alike felt that any means necessary justified keeping the colony and their covenant intact. Williams was sentenced to banishment in October 1635. ${ }^{12}$ The Roger Williams incident proved that "If such wild ones could not be tamed, it was best to cut them loose, lest they overturn the entire enterprise" (Morgan, The Puritan Dilemma 132).

That spring, after the departure of Williams, Anne Hutchinson presented herself as another challenge to church leadership. Morgan points out that "All we know of Anne Hutchinson was written by other hands than hers, for the most part by writers whose main purpose was to discredit her. Yet the force of her intelligence and character penetrate the libel and leave us angry with the writers and not with their intended victim" (The Puritan Dilemma 134). Her ideas presented a clear challenge to church leadership: Hutchinson's controversial home meetings reflected how Puritan congregations tended toward Arminianism - the argument that individuals could influence their own salvation giving way to discrediting the idea of predestination (Archer 31) — which pervaded the history of Puritanism from the onset (Morgan, The Puritan Dilemma 137; Elliot 39). Her meetings revealed the conflict between a "covenant of grace" versus a "covenant of works." She argued that morality and good character, known as sanctification, were not signs of

\footnotetext{
${ }^{12}$ When he magistrates set out to apprehend him, Williams fled in the dead of winter to Rhode Island (Miller, The Puritans 215; Morgan, The Puritan Dilemma 128-130).
} 
justification. "The fact that a man behaved in a 'sanctified' manner, breaking none of the laws of God, was no evidence that he was saved. In Puritan terminology this meant that 'sanctification' was no evidence of 'justification,' that men's lives in this world offered no evidence of their prospects in the next. The orthodox Puritans never claimed that the correspondence was perfect... it was usually possible to recognize sanctification, and that sanctification resulted from justification was not to be doubted at all" (Morgan, The Puritan Dilemma 138-139). Hutchinson's claims put too much power in the hands of the individual and went as far as to hint that Puritan ministers had in essence been teaching a "covenant of works" rather than a "covenant of grace" to the colony (Morgan, The Puritan Dilemma 138-139). One of the more threatening points of the Antinomian episode is the obvious influence Hutchinson's home meetings had on the laypeople of the church

Throughout her examination, Hutchinson cleverly turned the questions on Winthrop, who presided over the trial, and challenged leadership at every turn. "She was supposed to be submissive before authority and to answer inquiries directly and meekly, and he was supposed to be in charge, not on the defensive against her insolent attack" (Archer 46). In the end, she could not be charged with anything except "countenancing and encouraging" his supporters, holding meetings of mixed sexes in her home unfitting a woman, and that she disparaged the ministers of the colony (Morgan, The Puritan Dilemma 148-150; Archer 46-47; Hall, "Examination" 319-336). The charges against her were nearly dismissed by John Cotton's testimony if Hutchinson had not launched into an account of divine revelations made to her by God. Her own statements reflected evidence of heresy straight from her own mouth. Her fate, like Williams' fate, was sealed. "Neither 
Cotton, nor Wheelwright, nor Hutchinson, nor any of the others had posed a danger to the survival of Massachusetts Bay. "What they threatened was the authority of the standing order, the hierarchy... Hutchinson was banished and excommunicated, because she did not accept her place as a church member or as a woman and she was encouraging others to act similarly" (Archer 50-51). Van Engen argues that much of this narrative about Hutchinson being a great disturbance developed from the trial itself (104). Left unchecked, untamable people and dangerous opinions could fissure the colony, "her fall would reassert the authority of clergy over laity, magistrates over subjects, and men over women" (Archer 45). While the leaders and ministers of the Bay colony thwarted these outside threats to their establishment, they were less stalwart and less prepared to handle challenges from within their theological vision that threatened to reduce their churches to a small handful of ineffectual, unorganized men. The difficulty would be in who qualified to fill the churches and continue the tight control they had achieved thus far.

In addition to these threats to church leadership, dwindling church membership created a particular threat to the Congregational church. Many historians argue that it was the Puritan fathers themselves that created the low membership rates. A simple declaration of a conversion experience was all that was needed in the past, but under Congregational church governments, especially those in Massachusetts, the process required a rigorous, multi-step inquisition by a patriarchy made up of Puritan fathers anxious about the waning morality of the colony and of their own election to sainthood.

Puritans were anxious people to begin with, and for Puritan fathers to be anxious about their Puritan sons is not a great revelation because followers of the Puritan faith were created through an anxiety about their own election. The very nature of the Puritan 
theology of predestination told them that they are sinners and are helpless to avoid their sinful natures unless they are one of God's chosen to be granted grace. Because of Adam's fall, man's free will was gone and if he lived forever or burned in hell was decided solely by God. And yet, the theology goes on to insist that man strive to attain God's grace though he will never truly know if he has acquired it. This constant insecurity permeated their state of mind.$^{13}$ Richard Middlekauf, in The Mathers; Three Generations of Puritan Intellectuals, 1596-1728 (1999), notes: "The most familiar figure among the Puritans was the tormented soul, constantly examining his every thought and action, now convinced that hell awaits him, now lunging after the straw of hope that he is saved, and then once more falling into despair. He wants to believe, he tries, he failsalways on the cycle of altering moods" (7). Yet, the tensions between the Puritan fathers who crossed the Atlantic and their subsequent generations caused them additional anxiety. The generational gap between the Puritan fathers and their children was wide. ${ }^{14}$ Despite any inner turmoil they may have dealt with, these Puritan fathers are the men who left England because they believed their king no longer held the covenant with God. They cut out a patch within the wilderness to create the promised land and, by all accounts, were very successful. Emory Elliott, in Power and the Pulpit and Puritan New England (1975), claims that the fathers were reluctant to concede their success to their sons and describes a "general repression of the younger generation" (18-20). If their election was at question within themselves, the children didn't always see it reflected in

\footnotetext{
${ }^{13}$ Morgan also discusses anxiety over election, Visible Saints 66-67.

${ }^{14}$ Because scholars disagree and are inconsistent with the time periods and people which fit the categories of first, second, and third generation Puritans, I use the term Puritan fathers to describe the men who were born in England and migrated to New England. Their sons are what I term first-generation. And the sons of these first-generation are what I term second-generation, and so on through the third-generation Puritans.
} 
their father's outward actions. What was reflected was a confusion over where the succeeding generation's roles would lead that left the first generation uncertain: leaving the second generation uncertain and confused as well.

In addition to their confusion over assuming their fathers' roles was the everpresent anxiety over their own calling and election to God's chosen, an uneasiness felt immensely by their fathers about why their own children had not experienced regeneration. By the nature of being the seed of these saints, and thus being baptized, they were but "half-way" to sainthood themselves (Miller, "Preparation" 256). But halfway would never be considered regenerate. Can one be half-way to salvation? Half-way to heaven? Miller states that the Bible makes it clear that churches must be constituted by "visible saints, adults who had experienced regeneration" ("The Half-Way Covenant" 679). The explanation seems simple enough except that the Bible also taught that God extended his covenant to their seed and it was this covenant that allowed members to baptize their children. This provision could have been the solution for the continuation of the church but the baptizing of the children of saints still did not give them access to the Lord's supper or make them church members. To be a full member of the church, according to Puritan theology, one must declare that they have received Christ's grace. In the early years this was established through a simple declaration. ${ }^{15}$ Edmund Morgan argues that a more complex narrative and a "testing [of] prospective members of the church for signs of saving grace" is unique to the Puritans of Massachusetts (Visible Saints 65-66). Generations before the move to New England, Puritan ministers had taken

\footnotetext{
${ }^{15}$ Elliott claims that just saying you have received grace was enough, Power and the Pulpit 37. Demos claims that this relaxed approach to church membership may have happened in Plymouth but that churches in Massachusetts Bay were less accepting of a mere declaration, A Little Commonwealth 8.
} 
it upon themselves to account for conversion in order to help men recognize their progression toward salvation. ${ }^{16}$ Morgan finds no evidence of any Puritan minister in England involved in any actual testing of the faithful (Morgan, Visible Saints 76) for followers of John Calvin knew that positive identification of God's elect was impossible and therefore those predestined for heaven were known only to God himself. Yet, by 1640 New Englanders had developed a procedure for admitting new members. Morgan offers a summation from several Puritan texts of the process by which a candidate obtained church membership. ${ }^{17}$ First, a personal interview that examined his biblical knowledge and religious experiences. Second, church members were expected to offer evidence against the candidate of any offenses both private and public. If none were offered or offenses were explained away by the candidate to the satisfaction of the elders, the next phase was a character witness panel of sorts and a fifteen-minute narrative of God's work on his soul followed by a Q\&A portion. It is this demonstration, this proof of saving grace, that was a unique addition to the New England Puritans. "It meant that every member of a New England church must be able to describe personal experiences" (Morgan, Visible Saints 90) that correspond to theology and show, as Thomas Lechford characterizes, "that they have been wounded in their hearts for their original sinne, and actuall transgressions, and can pitch upon some promise of free grace in the Scripture, for the ground of their faith, and that they finde their hearts drawne to believe in Christ Jesus" (qtd in Visible Saints 90). And, he must be able to articulate it to the inquisitors.

\footnotetext{
${ }^{16}$ Morgan offers this explanation instead of the assumption that rigorous testing was used to ferret out those who were not regenerate. Visible Saints 66.

${ }^{17}$ Morgan draws from sermons by John Cotton, The Way of Christian Churches in New England and Richard Mather, Church Government and Church Covenant Discussed in Visible Saints 88-90. Hall, The Last American Puritan 20-21.
} 
While the process became something of a template, and most answers by candidates were similar in form as all the others, this dissertation argues that this type of process toward membership into the Congregational churches of Massachusetts Bay is a moderate type of tribunal that reflects both the leadership's anxiety for their covenant and their concern over potential challenges to their authority. These inquisitions conflicted with the precedents set by earlier Puritan ministers and were in direct conflict with elements of the theology itself.

The inquisitor and those subject to the inquisition shared a similar anxiety. Though each individual could be confident that God would fulfill His covenant promises, "the problem for each individual was one of knowing whether the covenant had actually been extended to him" (von Rohr 196-197). This "knowing" was a source of constant anxiety. Early Protestants expressed the importance of being called to election while simultaneously offering no assurances that an individual could have knowledge of his own election. John Preston, a notable early Protestant minister, expresses his own ambiguous wisdom, "If thou believe, it is certaine then, that thou art within the covenant." And yet, "[it is a] secret perswassion wrought in the heart, whereby God assures you that he is yours, and you are his." But then, "My beloved, it is a thing wee cannot express" (qtd in von Rohr 197). ${ }^{18}$ Unlike their English Puritan fathers the difficulty for Congregationalist was being able to express their regeneration. But Congregational leadership developed a process for church membership that essentially asked for proof of regeneration which had previously been deemed inexpressible. "Evidence, not reality, was the bailiwick of the churches, and their evaluation of evidence

\footnotetext{
${ }^{18}$ Von Rohr examines the idea of a covenant theology in practice to discuss how the assurance of election is both conditional and absolute.
} 
was confessedly faulty" (Miller, "The Half-Way Covenant” 692). If proof is asked for as part of the application for membership in the Congregational church, this statement is an admission that evidence is not always proof. "Congregationalism, we must recollect, was based on the theory that church-members were at least evidently regenerate" (emphasis mine, Miller, "The Half-Way Covenant" 696). How does this Congregational ideology of proof and evidence manifest in the community of Massachusetts Bay? Who can be believed and who is subject to scrutiny? When is the proof of something not subject to the presentation of evidence? For the moment, Congregational Church leaders were satisfied with admitting those who were at least evidently regenerate. This dissertation will return to the conversation of proof and evidence and offer the infanticide phenomenon as an example of Congregational ideology within the community of Massachusetts Bay.

With a system in place for accepting new members, the Puritan fathers had to face the problem of their own children not achieving regeneration and becoming part of the full covenant. Additionally, the children were becoming parents themselves which brought the rising issue of whether the children of the children of saints were entitled to baptism. After all, the assumption of the fathers was that the first generation of Puritans would invariably account for their own regeneration and become members. So, as the second generation of Puritans is born, the worry over the issue of baptism again plagued the church elites. After a series of synod that provided no resolution the issue was officially resolved in 1662 when the church decided to embrace what would be known as the Half-Way Covenant: a process for authorizing the inclusion of some and the exclusion of others through rights of baptism that were arguably not extendable to the 
children yet provided protection for the congregational numbers. Though not overwhelmingly popular, the theological defense for this move came as part of the argument that the regenerates were responsible for offering the unregenerate the means to conversion. The results of this synod became a solution for church organization rather than of divine clarification: practical rather than spiritual. And, a slight reprieve to the rising anxiety over church membership.

Upholding their adherence to theology virtually assured consistency with the polity and ensured the continuation of the commonwealth. Part of the attempt at the inclusion of new souls was to maintain the influence of the church itself over the colony (Archer 56). A Puritan community was "not an aggregation of individuals but as an organism, functioning for a definite purpose, with all parts subordinate to the whole, all members contributing a definite share, every person occupying a particular status" (Miller, The Puritans 183). Full church membership would extend privilege to many, and that membership should be guarded. The decision made by the synod of 1662 was both inclusive and exclusive: it bolstered the church hierarchy by including these children as part of a church covenant. Puritans trusted covenants; covenants were something they understood and agreed with. Having answered the baptism question with what was known as the Church Covenant, children of the saints through the Covenant of Grace could be welcomed into the church until they were called to regeneration. It wasn't simple membership numbers that mattered; membership was a tool for the clerical elite to govern the colony. The means for extending the patriarchal arm of church leadership was solved by the creation of this new organization for the church. This practical solution marks the moment when Congregationalism is transformed from a religious existence 
into a legalized order of the colony. Their focus was not on an individual's soul but of their larger concern for the colony.

The answer to church membership and their own children's election was to rely on their covenant. It is an easy mistake to look back at their prolific writings and postulations and think of these Puritan fathers as stalwart, sure, and decisive. Their apologies and propositions reflect a group of men who were working off the cuff. For every question answered, every difficulty surmounted, they faced a new challenge casting them once again into doubt and causing them anxiety. Such was the case of the accepted propositions of the 1662 synod. While solving the issue of baptism and the birth rights of the children of saints still more clarifications for church and state membership arose. The Covenant of Grace resolved who was regenerate and therefore a full member of the church. The Church Covenant solved who was admitted into the church congregation through rights to baptism. But that left many other souls dwelling in their colony that needed governing.

\section{Creating Colonial Law}

Good governing began with establishing colonial law. Winthrop and his company took their unique charter, and the autonomy it afforded them, and set to work on their mission. The king had endowed their charter with the authority "to make, ordeine, and establishe all manner of wholesome and reasonable orders, laws, statutes, and ordinances, directions, and instructions, not contrary to the lawes of this realm of England, as well for settling of the forms and ceremonies of government and magistracy fit and necessary for the said plantation" (qtd. in Morgan, The Puritan Dilemma 84) and the charter did not require that laws be consented to by settlers: Winthrop and the dozen company members 
who came with him had complete authority (Morgan, The Puritan Dilemma 85-86).

Whether Winthrop knew or not, though he likely did, he was embarking for a territory of anti-authority settlers. ${ }^{19}$ As Englishmen and Puritans, Winthrop and his men valued a strong local government to impose order and discipline (Konig 3-5).The governing triumvirate: Winthrop, governor; John Endecott, governor in extempore before Winthrop's arrival; and Thomas Dudley, deputy governor were, a "determined, stiffjawed set, quick to anger and slow to laughter" who were "authorized by their charter to exercise absolute powers of government; they were endowed by a temperament with the inclination to exercise those powers; and they were assisted by a philosophy of government which clothed every civil ruler in the armor of divine authority" (Morgan 8689). ${ }^{20}$ With their own arsenal of confidence, the providence of God, and authority of the King, Winthrop and his company men set to work on establishing their due form of government by extending voting rights to freemen to elect assistant while allowing only the assistants the power to elect the governor. By extending the voting rights, Winthrop effectively changed the charter into a constitution and the assistants into a legislative assembly (Morgan, The Puritan Dilemma 90-91).

At the next meeting, the trading company was transformed into a commonwealth. "The real answer as to why they opened the door to freemanship so wide is to be found in the terms of the commission with which they believed the colony was entrusted. The idea of a covenant, the fulfilling of a contract, between God and man occupied a pre-eminent

\footnotetext{
${ }^{19}$ David Thomas Konig, in Law and Society in Puritan Massachusetts, Essex County 1629-1692 (1979), remarks that many Bay settlers were opposed to reformed Congregationalism and of the nearly two hundred of those settlers only thirty were willing to sign a covenant, prior to Winthrop's arrival, at the first church of Salem in August 1629.

${ }^{20}$ Morgan, The Puritan Dilemma, attributes this "divine authority" to the Puritan belief that rulers who put God's will first were men ordained by God himself to manage civil government (88).
} 
place in their thought: it was the basis of an individual's salvation; it was the origin of every true church and also of every state" (Morgan 93 ). ${ }^{21}$ Where only thirty of the two hundred settlers signed the covenant written by the first church of Salem prior to Winthrop's arrival, ${ }^{22}$ the suggestion that voting freeman be members of a church practically secured the freemen's belief in the covenant as expressed by Winthrop and Cotton in the sermons naming the Massachusetts Bay mission a covenant with a special commission with God. To fulfill the covenant, they needed a government for establishing laws and a system of enforcing them. Winthrop believed the due form of government that would carry out their special commission would also need to be a covenant between the settlers and the ruling men of the colony: thus, the voting privileges were extended (Morgan, The Puritan Dilemma 94). There would be other uses of covenant for the Puritans but this agreement becomes known as the national covenant, a universal covenant that guides the entire community. ${ }^{23}$

This clever Puritan patriarchy found ways to systematically extend their control through measured designs in order to include and exclude people from various levels of participation in the church and in the colony by "[expanding] citizenship but [consolidating] authority" (Archer 29). While the inclusiveness of Winthrop's measure extended voting rights it also excluded the average man from voting on who, through legislation, controls the colony. With every decision, these Puritan fathers made the

\footnotetext{
${ }^{21}$ This dissertation will return to the issue of a covenant twice: when discussing the Half-Way Covenant and when examining the ministerial language in the sermons and narratives of the period.

${ }^{22}$ See also footnote 10 .

${ }^{23}$ This dissertation discusses the covenant of grace in Chapter 3 as part of the means for instituting the policy of exclusion and establishing what becomes known as the Half-Way Covenant.
} 
colonial leadership more clearly defined, and fewer in number: A small ruling leadership of men that set about limiting power in the colony.

It is also important to contextualize the philosophy of these assistants, the governor, and deputy governor who saw themselves accountable only to God, not to the people. As long as a ruler did his duty by God, he was free to exercise his power as he saw fit (Middlekauf 94). ${ }^{24}$ Puritans were keen to avoid a government ruled by the clergy because of their understanding of the papacy's unlimited authority in both ecclesiastical and civil politics (Middlekauf 95). While the Chesapeake colonies were formed first by charters granted to the London Company, and later populated by enclaves of religious refugees, the Puritan colonies were formed from the outset by founders looking to create a place of escape from what they saw as the declining English reformation (Powers 20). These Puritan colonists were seeking a new world order and a chance to construct a more orderly, morally stalwart society: one governed by God, and not for monetary profit. While other colonies were bound by the constraints of a corporation charter, whose investors expected to benefit from, Massachusetts Bay's joint-stock responsibilities never came on shore with them. ${ }^{25}$ This uncharacteristic freedom afforded to Massachusetts, the freedom of having a governing body in residence in the colony, their Puritan focus, and their special commission from God, make the Massachusetts Bay colony the focus of this research because these characteristics allowed them the autonomy to uphold their mission.

\footnotetext{
${ }^{24}$ One would suppose that the rulers of government in Massachusetts would also likely be ministers. That might have been the case except that ministers were not allowed to seek public office: in this area, their authority was limited. Morgan states "Indeed, of all the governments in the Western world at the time, that of Massachusetts gave clergy the least authority" (96).

${ }^{25}$ The company's finances were reorganized in 1629 before setting sail and the stock was purchased by undertakers dividing the trade from the governmental aspects of the venture. It was no longer a joint-stock body. The colony's purpose was the governing of a plantation (Powers 23).
} 
Colonial law, in general, was derived from English law but, prior to any codification of statutes by officials, each colony functioned under different ideas concerning criminal law. Legal scholars refer to the colonies as falling into two separate groups when discussing the establishment of colonial judicial systems: Chesapeake and Puritan colonies (Powers 103). ${ }^{26}$ By 1660, seven separate colonies had formed: Virginia, Maryland, and Rhode Island are considered to be the Chesapeake colonies; and Massachusetts Bay, Connecticut, Plymouth, and New Haven are referred to as the Puritan colonies (Chapin 3-5). The Chesapeake colonies had similar modes of expressing substantive law, actual written law defining what is illegal as opposed to procedural law, amongst themselves and derived their judicial law from common sources, as did the Puritan colonies. Bradley Chapin, in Criminal Justice in Colonial America, 1606-1660 (1983), defines the sources of substantive criminal law in each of the colonies into three categories: English, indigenous, and biblical. The use of the 'indigenous' category as a source does not refer to the 'frontier' life or native tribes. Chapin clarifies that the term is used to reflect two movements that were prevalent as a result of the Puritan discontent with English law: an attempt to remove the issuance of punishment for personal misconduct from church courts; and a general attempt to reform criminal law. As Chapin points out, the percentage of preference for 'indigenous' sources reflects the overall desire for both movements by all colonies. The following table reflects the derivational percentages to measure which existing source provided the most precedent for each colony:

\footnotetext{
${ }^{26}$ Powers states that many historians go as far as to refer to Massachusetts Bay and Plymouth as "Bible Commonwealths" and "Puritan Oligarchies."
} 


\begin{tabular}{lccc}
\hline Colony & English & Indigenous & Biblical \\
Rhode Island & 86.2 & 12.9 & 0.9 \\
Virginia & 81.1 & 18.9 & - \\
Plymouth & 59.0 & 36.7 & 4.3 \\
Maryland & 54.6 & 43.6 & 1.8 \\
Massachusetts & 41.2 & 20.0 & 38.8 \\
Connecticut & 38.8 & 21.2 & 40.0 \\
New Haven & 34.8 & 22.4 & 42.8 \\
& & & \\
Total & 56.5 & 25.1 & 18.9
\end{tabular}

Source: Bradley Chapin, Criminal Justice in Colonial America, 1606-1660 5.

It is obvious from the contents of this table that the three Puritan colonies drew, nearly equally, from English law and biblical law, while the other colonies relied very minimally on the bible. Chapin offers two possible reasons for these differences: one was the possibility of drawing attention from England if the establishment of laws was too radical; and, "Another reason for the dearth of explicitly biblically based law may have been that God's earthly agents were not so immanent in Plymouth as they were in the Puritan colonies" (6). The table helps substantiate the sources of criminal law but also reflects the more important issue of a regionalized agenda, like addressing sin, in the Puritan colonies.

One of the primary reasons colonists wished to reform English law was to govern personal conduct more strictly. Morgan notes that Winthrop and his assistants didn't need a law to restrict or punish colonists for their behaviors: "Guided by the laws of God as set down in the Bible and fortified with the absolute authority to enforce those laws in any way they saw fit, they felt little need for explicit legislation" (97) and early Puritans relied on "brotherly admonishment" as a means of social control (Konig 130). Harkening back to Winthrops' words on the Arbella, "our community as members of the same 
body" meant that policing each other was like policing yourself and all were "knit together in this work as one man" to maintain the special commission. Yet, not everyone was at liberty to levy outright punishments, which were reserved for Winthrop and his assistants. This concept of doing God's work through God's deputies gave Winthrop and his assistants the freedom to construct a unique judicial system that would deliver punishments as God instructed and as the colonial magistrates desired. Still, the need for a codified system of statutes would eventually be necessary to keep the wilderness at bay, and to be able to admonish even the non-believers, and would result in the creation of the Massachusetts Body of Liberties in 1641.

Massachusetts, Connecticut, Plymouth and New Haven had shared religious views and shared moral achievements, so therefore presented no immediate need for written laws, until an influx of "unworthy persons" into the colonies in the later part of the 1630s. Colonists also knew they risked admonishment from England because of their differing opinions from England. "The Puritan magistrates knew that much of their criminal law, sex crime and larceny for example, could not meet the chart-mandated requirement of consistency with English law" (Chapin 20-21). Therefore, the need to define their own set of criminal codes was evident. Massachusetts's codes were therefore established in 1641 and 1648 and Connecticut's in 1642 and 1650. The definitive differences between English law and the Massachusetts and Connecticut codes for serious offenses were the use of biblical terms and the citation of biblical passages for support. Edwin Powers points out, for example, that the Biblical expression "shall surely be put to death" is used specifically in four of the laws rather than the more modern colonial expression of "shall be put to death" (255). Powers suggests that the first twelve 
capital laws signed into authority were anchored in the word of God and that the magistrates meant these laws as a warning to everyone that violations of the "new Hebraic-Puritan code of social behavior would be severely dealt with" (264). There was no need to clarify by whose authority these laws and punishments would be carried out: it was God's law that Puritan magistrates put before man's law. Each capital law had a scriptural counterpart. For instance, the capital crime of murder was written as:

Colonial Law: If any person shall

commit any willful MURTHER upon

premeditated malice, hatred or cruelty, not in mans necessary and just defence, nor by meer casualty against his will, he shall be put to death, Exod. 21:12:13; Numb. 35:31.
Biblical Counterpart: He that smiteth a man, so that he die, shall be surely put to death-Exod, 21:25. Moreover ye shall take no satisfaction for the life of a murderer, which is guilty of death: but he shall be surely put to death-Numb. 35:31. Who so sheddeth man's blood, by man shall his blood be shed: for in the image of God made he man-Gen. 9:16. Thou shalt not kill-

Exod. 20:13. (Powers 258-259)

The language, the written scriptural counterpart, and the inclusion of biblical passage notation in the laws made it clear that the Puritan magistrates were keeping their covenant with God.

In addition to their preference for biblical practice, Puritans believed that the magistrate himself was God's deputy and the Puritan colonists empowered magistrates as such. While governors of the Chesapeake colonies answered to an earthly authority, 
Puritan magistrates answered to the ultimate authority: God. Given that Puritan thought was influenced by sixteenth-century theologian John Calvin, who explicitly described magistrates as God's "deputies" who were asked to do God's bidding on earth, discretionary justice was expected and accepted. The idea of discretionary law was inherent in John Winthrop's opinion and he defended this position in his publication Discourse on Arbitrary Government in 1644. He claims that where God's Law is silent, meaning that there is no biblical reference to a crime or its subsequent punishment, God's magistrates are free to use their own discretion. Puritan colonies dealt with substantive law differently from the other colonies (Chapin 17-19).

Despite the principal foundations for the establishment of any colony, they were still English subjects and still answered to England. The basic guiding principle for the construction of law statutes by Winthrop and his assistants was to be consistent with and to avoid direct contradiction with English law. Massachusetts' founders, however, had no limitations to their authority where the construction of law was concerned (Chapin 4). This research investigates the inclusion of concealment. It is essential to this dissertation to show how the deteriorating state of the social and economic systems in England brought the crime to the attention of their courts in order to show how the colonists disassociated infanticide from the mother law--English law--for what they saw as fundamental law: God's law.

\section{English Infanticide Becomes Concealment in Massachusetts Bay}

Scholars and historians have discovered that the $17^{\text {th }}$ and $18^{\text {th }}$ century court and criminal record keeping was sparse in some areas of England and New England, and thorough in others. This fact makes infanticide research difficult. However, as Hoffer and 
Hull note, where they provide an exhaustive compilation of available infanticide statistics, court records for New England are more accessible because the less dense population of the colonies made record keeping easier (Hoffer and Hull xvi). In addition to Hoffer and Hull's work, thorough studies of the crime by other scholars have created a wealth of statistics and data on the actual infanticide numbers, as they are available and accessible, for both England and New England. Though extensive investigation of the crime of infanticide in England is not the focus of this dissertation, it is important to note what scholars have discovered to be the key differences in the cultural context and causality between England and New England infanticide cases. In other words, the numbers alone don't tell the story; rather, the circumstances for the rise in infanticide numbers in both regions correlate with their own social and political demographics. ${ }^{27}$ The statistics would suggest that infanticide crimes were occurring and being prosecuted equally in both regions. However, medical historian Mark Jackson claims that cursory glances at statistics lead to misleading assumptions (Jackson, Newborn Child Murder: Women, Illegitimacy and the Courts in Eighteenth-century England 5.). It is only with a careful eye for the consideration of the social, economic, and religious factors unique to each region that the human story of infanticide becomes real for us as modern readers.

In the 30 years prior to 1600 , criminal cases brought before the court of assize grew 250 percent. ${ }^{28}$ Assize Courts held public sessions that heard the most serious crimes

\footnotetext{
${ }^{27}$ I am grateful to Hoffer and Hull for equating the differences between the court structure and the record keeping between England and New England that enabled them to produce a distinctive set of statistics that allow us to see comparisons between those individuals who were suspected or tried, and the subsequent punishments, for infanticide crimes in both countries.

${ }^{28}$ Assize Courts were six regional courts that met semi-annually when two judges rode to each once in the winter and once in the summer. Judges were also judges in the superior courts of common law and would have been knowledgeable and experienced in investigatory skills. See also Martin 22; Sharpe 23; and Jackson, Newborn Child Murder 3.
} 
in England. Judges were appointed by the Privy Council and travelled between circuits, generally, twice a year (Martin 22), increasing the length of time between the crime and any judicial action. And though the population of the country had also increased, scholars feel that the rise in population alone cannot justify the increase in criminal investigations in England. ${ }^{29}$ Numerous scholars have argued that the rise in the number of infanticide cases on both continents between 1630 and 1730 is comparable. Scholars claim that because the colonies were not yet independent then the environmental factors and legal systems cannot be different in cases of infanticide. At first glance that may seem true, but the underlying causes and the increase in investigatory motivation by English courts was different from that of the colonies, which resulted in a higher number of suspected cases and convictions in England that are specifically related to population growth and social welfare concerns.

For early English courts, infanticide was seen simply as a crime of murder. The first inclusion of an infanticide case in Fitzherbert's 1584 law publication is included solely to discuss the culpability of accomplices. ${ }^{30}$ The text disregarded the age of the victim as well as the moral status of the suspect, thus rendering all of these elements unimportant to the prosecution of the crime itself. By the time the revision of Fitzherbert's law manual was published in 1593 , an additional infanticide case was included with the note: "a harlot is delivered of an infant which she puts alive in an orchard, and covers with leaves" (qtd. in Hoffer and Hull 7-8). Though this second

\footnotetext{
${ }^{29}$ Several scholars are credited with this idea: Hoffer and Hull 18; Jackson, Newborn Child Murder, 45; Sharpe 49.

${ }^{30}$ Manuals were issued to justices as reference guides. Anthony Fitzherbert's law manual was felt to be the most authoritative of its time. The enlargement of the Fitzherbert manual came in 1584 by legal writer Richard Crompton and published in 1593 (Hoffer and Hull 6-7).
} 
English case was not a landmark in its time, the notation reflects two significant factors of the time period: concern over the moral status of the woman and the concealment of the victim.

Aside from the growing interest among judicial leaders in defining infanticide, there was a growing concern in parliament for social disorder. The realities of social disorder meant that everyday occurrences of thieves, drunkards, vagabonds, and beggars plagued the community. In addition, "Many [of these] 'night-walkers and day-sleepers' turned to crime as a way of life, and their numerous illegitimate offspring were a drain on local institutions of relief ... resulting in a fear of crime and an anxiety about social instability" (Konig 4). ${ }^{31}$ This need for conduct rules resulted in parliament's establishment of the "poor law" in 1576. "Poor laws" were not meant to unearth the causes of poverty but to alleviate its effects on the community (Hoffer and Hull 13). Because illegitimate children, along with orphans, became wards of the parish and consequently became physical and monetary burdens, sexual misconduct resulting in a pregnancy could become a financial burden for the entire community. The notation of the infanticide case in Fitzherbert's manual, and the addition of the word "harlot" establishes for the first time the connection between the moral status of the suspect and the crime (Hoffer and Hull 10), not for the moral rebuke the Puritans would use it for later but for drawing attention to the economic significance of her unmarried state. "Harlot" not only indicates an unchaste woman; the term also establishes the socioeconomic status of the suspect and the potential burden a bastard child places on the community: a community

\footnotetext{
${ }^{31}$ Konig is quoting material from Christopher Hill's The Century of Revolution, 1603-1714, 28. I use Konig here because his work is drawing a contrast between English and colonial society whereas Hill is discussing England specifically.
} 
overburdened with poverty (Hoffer and Hull 10). Since English "Poor law" established a monetary and physical punishment for bastardy, concealment of a bastard child would have been a means of avoiding these recriminations of the law (Hoffer and Hull 17).

Researchers have argued that the morality of the woman supersedes her economic status. However, the inclusion of bastardy in the construction of the poor laws indicates that money too was a concern. In England, pre-marital sex was accepted under the condition that in the event of pregnancy the couple would agree to marry. ${ }^{32}$ As Jackson has noted, "Pre-marital sex was generally a danger to the parish and a source of shame to a woman only if it was likely to lead to the birth of a bastard that would need to be maintained by the parish." In addition, a woman's family's disapproval was also only linked to the birth of a bastard and not the pre-marital sex (Jackson, Newborn Child Murder 46). ${ }^{33}$ Since the sequence of the events in England would have been the implementation of the poor laws in 1576, and then the revision of the Fitzherbert manual in 1593 to include the term harlot, it is arguably the importance of a parish burden that evokes the use of the term and not the moral remonstrative. Additionally, the Fitzherbert notation of the case of the harlot continues with "and a kite strikes at him with its talons, from which the infant shortly dies, and she is arraigned for murder, and is executed" (Hoffer and Hull 8). With or without the inclusion of the term harlot the charge would have been murder. The assumption is that the use of the term is to clearly indicate her motive for preventing herself from being punished under the poor law; fining her for her

\footnotetext{
${ }^{32}$ This dissertation returns to the concern for premarital sex later in this dissertation with recent scholarship from Kelly A. Ryan, Regulating Passion: Sexuality and Patriarchal Rule in Massachusetts, 1700-1830 (2014). This chapter is concerned with situating the origins of concealment in criminal law.

${ }^{33}$ Godbeer, in Sexual Revolution in Early America, states that this was true also of New England but this acceptance of premarital sex was vehemently opposed by Puritan ministers who were determined to reverse this acceptance in the New World (9).
} 
bastard child but not her unchaste behavior which was generally accepted by both society and by families and wasn't punished or chastised. ${ }^{34}$ In addition, the inclusion of the suspect's concealment of the infant doesn't imply the concealing of a sin, as the Puritans would view it, but rather a concealment of additional material for prosecution for poor law penalties.

Infanticide cases increased in number, both the total number of suspected cases and the number of guilty verdicts, after the institution of the poor law: "In the 17 years before [the Elizabethan statute that mandated poor law], Essex assize court juries found 2 of 5 mothers tried for bastard neonaticide to be guilty. In the 17 years after the poor law, juries found 9 of 13 guilty" (Hoffer and Hull 18-19). It has been suggested by scholars that the rise in number is due both to the increase in prosecution for murder and, more importantly, for bastardy and its concealment (Jackson, Newborn Child Murder 5; Rabin 75). It is more likely, as Hoffer and Hull have argued, that the rise in the overall numbers is due to the poor law. Both the community and the justices became more aware of infanticide through the process of ferreting out the crime of bastardy (Hoffer and Hull 18). During the late Tudor and early Stuart periods, infanticide cases became a major focus for English courts (Hoffer and Hull x). as reflected in the number of prosecutions, changes in the law, and in the shift of attitudes. Until the late 1500's, infanticide cases had little prominence in the English courts and were embedded in homicide cases (Hoffer and Hull 4) and received no other distinction, while in other parts of the world, infanticide cases were being discovered and prosecuted under different statutes (Jackson,

\footnotetext{
${ }^{34}$ Godbeer discusses this in relation to couples acknowledging their intent to wed (Sexual Revolution in Early America 3-4).
} 
Newborn Child Murder 4-5). ${ }^{35}$ Until then, cases of infanticide were treated with little distinction in the English court system. It seems that attention to the economic difficulties of sustaining the poor brought about the change in focus.

Bastard neonaticide constituted over 70 percent of all child-murders in England from 1576 to 1623 and concealment was mentioned in 55 percent of those cases. Also important to understanding the effect of the poor laws is the rate of conviction previously mentioned. As Hoffer and Hull have argued, “The heightened pressure upon authorities to find and punish bastardy among the poor and the increased incentive that the law gave the poor to perform infanticide increased the yearly number of mothers indicted for the crime of bastard neonaticide after 1576" (17).

Infanticide would henceforth be present in the courts of England, and bastardy and concealment would be two defining characteristics of the crime. The addition of a law against concealment would also make the prosecution of women easier. In 1624, English parliament passed a law regarding the prosecution of the death of a bastard infant:

An act to prevent the destroying and murthering of bastard children.

WHEREAS, many lewd women that have been delivered of bastard children, to avoid shame, and to escape punishment, do secretly bury or conceal the death of their children, and after, if the child be found dead, the said woman do alledge, that the said child was born dead; whereas it falleth out sometimes (although

\footnotetext{
${ }^{35}$ Jackson states that a surge in infanticide studies, because of humanitarian sentiments, has shown that historians are compiling statistics that show infanticide to be present in almost every country in Europe. Julius Ruff shows that laws and court procedures were revamped in various years from the early 1500 's in France through the late 1700's in Germany and Spain.
} 
hardly it to be proved) that the said child or children were murthered by the said women, their lewd mothers, or by their assent or procurement:

II. For the preventing therefore of this great mischief, be it enacted by the authority of this present parliament, That if any woman after one month next ensuing the end of this session of parliament be delivered of any issue of her body, male or female, which being born alive, should by the laws of either by herself or the procuring of others, so to conceal the death thereof, as that it may not come to light, whether it were born alive or not, but be concealed: in every such case the said mother so offending shall suffer death as in case of murther, except such mother can make proof but one witness at the least, that the child (whose death was by her was so intended to be concealed) was born dead. (qtd. in Hoffer and Hull 20)

The statute, 21 James I, c. 27, did not define a new law; murder was murder regardless of the victim. The statute expressed the difficulty over the technical problems of evidence in neonaticide cases and connected the key socioeconomic and moral characteristics of bastardy and lewd women.

The technical difficulty lay with the inability to be sure that the child was dead before being hidden, thus complicating the mother's culpability. Therefore, the statute takes away the question of culpability by simplifying the circumstance: if there is a bastard child born and the mother hides the body of the child, every mother is guilty of murder unless she can produce one witness who can vouch that the child was born dead. The burden of proof is on the mother to prove the child was dead before she buried the 
body: the defense has to prove innocence rather than the prosecution proving anything beyond the discovery of a corpse.

The tone in the 1624 statute is accusatory. As Hoffer and Hull note, "The preamble condemned sexual promiscuity almost as much as murder, and the law applied only to mothers of bastards" (22). Evaluation of the passage of the statute through English courts reveals evidence of the Puritan influence. Of the 21-member committee charged with the creation and revision of the concealment statute, from its introduction on April 17, 1624 through to its passage on May 27, 1624, four were acknowledged leaders of the Puritan party, and two others were confirmed supporters of the party. "Puritan participation in this committee was equaled only by their interest in Sabbath day laws" (Hoffer and Hull 22). The lack of initiative and interest in other legislation reflects their religious motivation in parliament.

The 1624 statute alerted jurors to the illegitimacy of victims and established guilt based on circumstantial evidence and the sexual misconduct of the mother. In Essex, between 1610 and 1622, only three unwed mothers were prosecuted for the death of the infant, with two convictions; in the twelve years after the 1624 law, 13 were prosecuted, with 11 convictions. In cases of legitimacy, the 1624 law did not apply; however, the cases of conviction against women with legitimate newborns were equal in the years prior to 1624; after, the convictions were fewer and more acquittals were given to mothers of legitimate newborns (Hoffer and Hull 23). These numbers seem to reflect the ease with which convictions were carried out against women in cases of illegitimacy, because the 1624 statute placed the burden of proof on the defense. Consequently, the 
women in cases with legitimate children were under less stress to prove their innocence because they were not tried under the same statute.

A broader study found the numbers for Essex Assizes from 1601-1665 to be a total of 60 cases, 53 of which refer to the victims as bastards. Fifty-one cases were brought before the court after the 1624 statute. The motive for concealing a birth would have been strongest for "bastard-bearers" (Wrightson 12). These numbers, both prosecuted and convicted, reveal how vulnerable single women were to the recriminations of the 1624 law.

Infanticide was almost exclusively a female crime even before the passage of the 1624 law, and the majority of those women were unmarried (Hoffer and Hull 102; Jackson, Newborn Child Murder 27). Though men were theoretically punishable, even the 1576 Act ordered significantly more frequent punishments for women. Jackson argues that this inequality can be viewed as a double standard implying that women's sexuality was a greater evil because of the consequence of bastardy, and the ease of convicting the mother rather than the father (Jackson, Newborn Child Murder 28). According to several scholars, the total number of cases involving men in newborn murder ais low (Hoffer and Hull, 21; Jackson, Newborn Child Murder 4-6). Not to mischaracterize the corresponding effects of the 1624 statute in New England, it must be said that the statute appears to have been created in English courts because of the increase in the number of infanticide cases being brought to court after the poor laws of 1576. Whether the intention of the statute was to target single women or women's sexuality is unclear. However, there are two things to note about infanticide in England: bastard children created a heavy financial burden on parishes, making unchaste women the target 
of a new statute; and the heavy involvement of Puritan directly influenced the creation and passage of the statute. As defined in my next section, these two characteristics prove to be very convenient for the Puritan agenda in the colonies.

Infanticide was nothing new to the colonists. The discussion of the 1624 infanticide statute began in English legislation in 1606 (Wrightson 11). Since the 1576 Poor Law in England brought infanticide front and center for the attention of the courts, as well as the community, Puritans settling in the colonies would already have had firsthand knowledge of the crime. As governors and councils began to establish systems of justice for their colonies, infanticide and concealment were not their primary focus. A general system of laws was needed first. But colonists were intent on reforming what they saw as lax and immoral government, and for John Winthrop and his followers the intent of creating a "City upon a Hill" was God's mission for them (Hoffer and Hull 33). The Puritans feared the sinfulness of humanity and would exercise all of their powers, as God's chosen people, to prevent it. So, the Puritan magistrates established themselves as the highest courts in their jurisdictions (Chapin 69).

Infanticide was prosecuted as murder in both England and New England until the 1624 statute was ratified. The 1624 statute was not incorporated into Massachusetts law until 1696 and then in Connecticut in 1699. Therefore, infanticide crimes were prosecuted as common law murder until then. Colonial courts did not need the guidance of the 1624 statute to find unmarried women suspected of the neonaticide guilty of murder; they "found ways to deal with concealed infant murder as severe as those in the Jacobean courts" (Hoffer and Hull 40). Yet, the incorporation of the statute into colonial law would make it easier to convict single women than married women. In England, the 
institution of the 1624 statutes generated more convictions in the 12 years after the statute was enforced than in the 12 years prior. The efficacy of the 1624 statute in the Puritan colonies is more difficult to discern and seems to be spread over a longer period of time. ${ }^{36}$ In the years prior to the statute, 1696 , Massachusetts juries were convicting suspects at a rate comparable to the conviction rates of England already functioning under the 1624 statute. Yet, for the years 1670-1780, Massachusetts' conviction rate was 2.15 times higher on average than in Essex, England (Hoffer and Hull 38) with the highest average developing between 1670 and1730 (Hoffer and Hull 183). Of the 71 cases of infanticide prosecuted in Massachusetts between 1670-1780, Hoffer and Hull suggest that 51 of those would have also been punishable under the 1624 statute's guidelines, with the greatest number of cases and convictions developing in 1690 (Hoffer and Hull 39-41). In other words, 51 cases brought to court involved a bastard child, a woman previously censured for her conduct, and the concealed body of an infant. The rate of conviction is not the immediate concern of Hoffer and Hull, who point out that in Massachusetts, the conviction rate for infanticide from 1630 to 1692 was much higher than conviction rates for the murder of an adult (Hoffer and Hull 44-45). The capriciousness of the colonial magistrates' severity is manifested in the disparity between those two conviction rates. It's not that the magistrates felt any less repugnance for murder of an adult, but rather, the punishment for the crime of infanticide suggests that there is a greater issue than murder involved in these cases.

\footnotetext{
${ }^{36}$ Since the research here argues that England indictment rates were escalated because of the motivation to reduce the economic burden on the parish for bastard children, the higher rates were more immediately evident. In the colonies, the motivation to suppress sin would be the reason for the rise in the indictment rates and would thus be dispersed over time.
} 
The discourses surrounding infanticide in New England are about more than crime and punishment. Because the 1624 English statute officially incorporated into Massachusetts Bay law in 1696 made concealment of a death a crime, actual evidence of a murder was no longer needed to convict a woman. Regardless of the 1624 guidelines, most cases were brought against women who were unmarried, and the number of suspected cases was likely even greater than historians or legal scholars have determined. ${ }^{37}$ Though England used the statute, its agenda was to suppress the economic burden of bastardy. In the Puritan colonies, as I will show later in this dissertation, the covenant with God was the priority and suppressing sin was the motivation for the illegality of infanticide. As shown in this chapter, the Puritans created their own system of criminality and punishment in the colonies, a system that went unquestioned by the body politic, a colonial body infused with the God's word and delivered through a symbolic language that was made real through enforced literacy practices by the ministers and magistrates.

These anxious Puritans faced many issues in the establishment of not only their colony but of their Congregational church. The sermons produced by the Puritan fathers and the first generation Puritans reveal more about the state of mind of these anxious people. My dissertstion discusses the important of literacy to Massachusetts Bay and analyzes the structure, purpose, and use of the jeremiad as it moves from election day sermon to the gallows to become the most popular form of sermon in New England. This dissertation questions the change of use for these jeremiads and explores their function as

\footnotetext{
${ }^{37}$ The actual rate of infanticide was greater than the number of cases brought to trial (Jackson, New-born Child Murder12).
} 
literary devices used by these anxious Puritan ministers to bring the colony to repentance for perceived sins of the community. 
CHAPTER TWO

LITERACY AND PRINT CULTURE:

THE JEREMIAD BEYOND THE PULPIT

In the beginning was the Word, and the Word was with God, and the Word was God.

John 1:1

As offspring of the Reformation, a large part of colonial Puritan ideology centered on the ability to read and accessibility to the Word of God. While not every colonist would have labeled themselves a Puritan, and conceptualizing the colonies as a single, cohesive culture would be a misrepresentation of New England, it is clear that popular religion played a major role in the everyday lives of early colonial Americans. This chapter frames the establishment of the Massachusetts Bay colony and the challenges the church leadership faced in the tenuous, early years of the settlement. The previous chapter also made a case for investigating Massachusetts because of its unique charter and adherence to biblical precepts for establishing law codes and introduced the 1624 statute for concealment brought over from England. Chapter two shows how the dominant religion is reflected in the popular religion of the Puritan colonies, particularly that of Massachusetts Bay, through an examination of literacy practices and the development of a print culture, governed by Puritan ministers, in order to contextualize the use of the unique American invention of the jeremiad: first as a fast day sermon and then as crime literature. My research is less concerned with the traditional practices of 
religion: church membership; meetinghouse attendance; or individual signs of devotion, and is focused instead on the use of religion within the community to understand the cultural production and consumption of religious language produced in the jeremiad and subsequently used at the hanging of a woman convicted of concealment under the 1624 statute in Massachusetts Bay.

Many elements of the dominant religion became part of the communal life of the colony, making it also the popular religion. David D. Hall, in Worlds of Wonder, Days of Judgment: Popular Religious Belief in Early New England (1989), discusses how religion and religious belief in early America differed from England for several reasons. Not only was the physical landscape significantly different but, as the colonists cut out their place in the wilderness, "the social and the spatial order of New England was radically decentralized" from their previous existence in England (6). The distance between colonial settlements was vast, settlements were sparse throughout the region, and these scattered towns relied heavily on the minister's residency as a unifying force for order in what was a seemingly chaotic new world. As the Puritans exited Europe, the Protestant Reformation left behind the altars, the cathedrals, the Book of Common Prayer, the tithing, and the church hierarchy along with other discernible iconography and religious practices. The people who were the stalwarts of the Reformation in England were the people who now occupied this vast new space. Meetinghouses were strategically placed at the center of town as both a means of establishing and maintaining order in a physical landscape bordered by wilderness served as visual deterrents to chaos (Demos, A Little Commonwealth 12-13; Wall 2-3). Puritan religious leaders established themselves as magistrates, as shown in the previous chapter, and their physical presence helped 
substitute for the lack of the religious iconography. In turn, they also influenced the daily life of the community and shaped the way colonists viewed themselves, each other, and their world.

Though they left behind the artifice, colonists brought with them a vernacular religion, one in which religious services and texts were spoken and written in the common tongue, and the clergy helped maintain a common system of rules and values through their constant presence in the town. As a vernacular religion, absent of iconography and religious edifice, there is no comprehensive way to measure the individual's commitment to religion (Hall, Worlds of Wonder 4-8). There were no altars or religious figurines or paintings of the Madonna and Christ child as symbols of reverence or piety to be found in Puritan homes. Yet, the everyday lives of the people in early America reflect the prevailing influences of a popular religious belief; colonists used "a loosely bounded set of symbols and motifs that gave significances to rites of passage and life crises" (Hall, Worlds of Wonder 18) helping to make sense of their extreme circumstances and strange new world. In place of religious edifices and altars early Massachusetts colonists, "God's chosen people," looked to ministers to explain phenomena in their "city on a hill" so that a crop failure was interpreted as God's displeasure, or a thwarted Indian attack was a sign of God's favor. Ministerial writings, in both the meetinghouse and in print form, created a consistent voice between the colonial leadership and the community.

Though the outward signs of a religion were absent, popular religious belief infused and was infused by the way in which colonists came to understand their new world and their place in it through the mediation of the Puritan religious leaders. Emory 
Elliott, in Power and the Pulpit in New England (1975), claims that early colonial sermons reflect the anxieties of these first and second generations of Puritans. While colonial Puritan fathers faced the external struggle of a transatlantic journey and a new settlement, their internal, private writing reflected a wilderness within themselves too. Yet, these fathers successfully presented their children and congregants with outward messages of confidence and independence. Besides the changes in landscape and religious edifice, threats from hostile Indians, disease, drought, and the ever-pending threat of the loss of the Massachusetts Bay Charter plagued the first generation of Puritans. Sermons of the second generation expressed the threat of failure, inadequacy, and insecurity of meeting the expectations of their forefathers. For the average readers and audiences of early America, sermons provided an explanation for God's wrath and a means for winning back God's favor. Elliott juxtaposes the personal diaries and autobiographies of some of the most important Puritan ministers in the seventeenth century to show that sermons do not always reflect real threats but a connection between personal struggles and external events “... while the diaries tell us of the deep inner struggles men endured, it was the sermon that provided the outlet for public expression of the deepest tensions of the society..." (10), making the minister's presence both a reflection of and an influence on the everyday life of the community. As a result, the sermons they produced encouraged self-examination and attempted to ferret out these secret causes of inner corruption. For us, students of history and creatures of inquiry, the personal and public writings of the period provide an insight into the thoughts and fears of the colonial society. This chapter focuses on the importance of literacy to the Puritan community and shows how the process of becoming literate was directly tied to 
becoming religious. The use of that literacy became a commodity for exchanging community values and expectations connected to the religious life they led through a tool only available to God's magistrates: the sermon. While an examination of the private writings and diaries of the Puritan era are valuable, my research is concerned with the function of the sermons, both spoken and written, within the community.

The vast, fertile wilderness of both the colony and the colonist inspired fear and hope in the early years of migration. As the colonies grew in both territory and population, it was the ruggedness of the individual soul that would concern the second generation of Puritan ministers. But for the early settlers, their primitive life created a great reliance on ministers for limiting chaos and for explaining phenomenon. Helena M. Wall, in Fierce Communion: Family and Community in Early America (1990), argues that it is difficult to "recapture the primacy of community in colonial America" (vii). Indeed, most scholars agree that the difficulty in pursuing any scholarship in early American studies is framing the contemporary mind to fathom this primacy, both spatial and mental. One such difficult element of reconstruction is the Puritan preoccupation with being able to read the Bible and how that preoccupation made literacy one of the primary sources of influence of popular religion and popular literature on the members of the Massachusetts community.

The content of these public sermons, and the drama they produced, shift from internal reflection to external accusation of others as the first and second generation of Puritan ministers struggled with the changes in their colony. Their struggles gave birth to the uniquely American invention of the jeremiad sermon. This chapter explores the development and function of the jeremiad in colonial New England to frame the 
argument this dissertation makes for how these sermons become tools for sermonizing at the gallows of a woman for the crime of concealment and for using her postpartum body as the site of concealed sin.

\section{Literacy as Religious Education}

The fact that the Puritans established Harvard College just six years after settling in the wilderness is surely a testament to the value they placed in education. Still, with such a monumental achievement toward education it is easy to overlook the origin of this value. Though not as ambitious as universal education, the ability to read was of paramount concern. A large part of Puritan ideology centered on the accessibility to Scripture; the accessibility of God's Word in their own language was considered a fundamental right to the people of the Reformation. Hall points out that this emphasis on the ability to read Scripture for oneself was part of the Protestant doctrine sola scriptura, that truth lives in the Word of God (Worlds of Wonder 22, 34). More than a basic right, every Puritan household was charged with the education of their youth so that they could read the Bible. John Cotton was known to have urged parents not to just teach children to read but to "Learn them to read the Scriptures" (Morgan, The Puritan Family 87-88).

Reformers believed in the power of God's Word as the means for an individual's salvation. Article VI: Of the Sufficiency of Holy Scriptures for Salvation in the Articles of Religion, 1562, states:

Holy Scripture containeth all things necessary to salvation: so that whatsoever is not read therein, nor may be proved thereby, is not to be required of any man, that it should be believed as an article of the Faith, or be thought requisite or necessary to salvation (The Church of England). 
Therefore, the emphasis on reading was not only an educational imperative but one whose end was grounded in the belief that every person should have the ability to read and understand God's Word in order to receive salvation (Morgan, The Puritan Family 89 and Bremer 4-7). Such is the plea of Israel Loring of Boston, in the sermon "The Duty and Interest of Young Persons" (1718): "By all means see to it, that your children be taught to read, or else you'll deprive them of one great help to their instruction and salvation" (22). For Reformers, and this new generation of Puritans, the ability to receive God's Word directly from the Scripture, unadulterated in order to hear the truth of it, placed literacy at the forefront of Puritan life.

Yet, not all Puritan colonies would treat the issue of reading with the same importance. Though Plymouth would become part of Massachusetts Bay in 1691, concerns over education would not result in a legal mandate in the region until well into the eighteenth century (Demos, A Little Commonwealth, 12, 72, 142-144). But for Massachusetts Bay, as with the codification of criminal laws, religious edicts infused the legal system once again. Massachusetts School Law of 1642 states:

It is therfore ordered that the Select men of everie town, in the severall precincts and quarters where they dwell, shall have a vigilant eye over their brethren \& neighbours, to see, first that none of them shall suffer so much barbarism in any of their families as not to indeavour to teach by themselves or others, their children $\&$ apprentices so much learning as may inable them perfectly to read the english tongue, \& knowledge of the Capital Lawes: upon penaltie of twenty shillings for each neglect (Constitution Society). 
The language of the law does not call for an education, as a secular law may define, but for the ability to read. In conjunction with this ability, the directive also requires an understanding of the capital laws. While research suggests that writing was considered to be a skill one learned through proper schooling, reading was almost universal in the Puritan colonies (Hall, Worlds of Wonder, 32-35). ${ }^{38}$

Reading initially developed not through any formal education, according to Hall, but instead "emerged from a broader set of practices" (Worlds of Wonder 36-37), primarily those associated with practices of popular religion. "Literacy in New England was bound up with certain texts that doubled as introduction to religion and introduction to skills of reading" (Hall, Worlds of Wonder 37). The process of learning to read would have included the use of not only the Bible but primers which included Bible verses, parables, and stories of martyrs which fused literacy with religious education. Colonial leaders required that indviduals be able to read the capital laws which were accompanied by their biblical counterpart in the Scripture ${ }^{39}$ : thus, "in using these texts to learn to read, children in New England also absorbed the elements of a religious system" (Hall, Worlds of Wonder 38). This system established authority through the everyday functions of hearing, reading, and speaking biblical language in the presence of a minister: "Literacy and religion were inseparable" (Hall, Worlds of Wonder 38). As a foundation for literacy skills, the illiterate learned to read while also learning how to function within the boundaries of religious expectation. Literacy and religion were governed by church

\footnotetext{
${ }^{38}$ Hall references several historical reports made in response to the Massachusetts General Court asking for "an account of the youth from the age of nine and upward, who cannot read," in 1668, to which the reports found no child unable to read. There are also statutes enacted in towns that required each home to also "become little schools" (34).

${ }^{39}$ The use of biblical scripture as counterpart to the capital laws is discussed thoroughly in chapter one of this dissertation.
} 
leaders and made law by the elected legislature. Every member of the community affirmed this authority through their participation in learning to read. And whether they were religious or not, their participation also made the dominant religion the popular religion because the source of literacy was also the church making biblical language part of the common vernacular.

There can be no doubt as to the importance of literacy as a means for religious education, and adherence to the sola scriptura, because the 1642 school law goes on: Also that all masters of families doe once a week (at the least) catechize their children and servants in the grounds \& principles of Religion, \& if any be unable to doe so much: that then at the least they procure such children or apprentices to learn some short orthodox catechism without book, that they may be able to answer unto the questions that shall be propounded to them out of such catechism by their parents or masters or any of the Select men when they shall call them to a tryall of what they have learned of this kinde (Constitution Society).

The basic instruction to the community is everyone should be taught to read their catechisms, and if there is no book to teach them, then they should be taught through memorization and everyone could be subjected to a spot quiz at any moment. The law goes on to suggest that children and apprentices may be taken from the parents if they are unable to meet the challenge. While the instruction, and the penalty, seem harsh to our contemporary senses, for the Puritans, the salvation of one's soul was paramount. And that salvation could only be obtained through the access to Scripture: exposure to God's unadulterated Word. 'Imagining themselves as the 'Lord's free people,' the godly... valued direct access to the Word of God as the most precious of their privileges" (Hall, 
Worlds of Wonder 18). Massachusetts would go on to create the School Law of 1647, known as the Old Deluder Satan Act, requiring schoolhouses for teaching reading and writing to thwart this very concern. If the wording of the act is any indication of the Puritan anxiety over the salvation of its members, the present threat, Satan, is clear: "It being one chief project of that old deluder, Satan, to keep men from the knowledge of the Scriptures, as in former times by keeping them in an unknown tongue, so in these latter times by persuading from the use of tongues, that so that at least the true sense and meaning of the original might be clouded and corrupted with false glosses of saintseeming deceivers" (Constitution Society). The act also names the former threat of the Catholic Church as being a willful deceiver of salvation who deliberately tried to keep the knowledge of the Scripture, from its members. The emphasis on salvation fused together literacy and religion for the new generation of Puritans. Even more, the ability to read was a responsibility of true believers, to be readers and to assist others in the ability to read.

Beyond their attachment to the precedent for literacy coming from the Reformation, Puritan households were now under the law. Even as early as the sixteenth century, English towns established statutes requiring Puritan households to become little schools: "So too in New England, the religious system merged with households in ways that ensured a near-universal literacy" (Hall, Worlds of Wonder 34). ${ }^{40}$ Whether one professed to be a Puritan or not, it was the communal duty and a legal one for the illiterate to become literate. The law bound together literacy and religion making the common religion the popular religion of the Puritan colonies. Yet, learning to read was

${ }^{40}$ See also, Morgan, The Puritan Family, 37-39. 
not the only result. They also learned to understand the religious framework of their community.

The Bible, the catechisms, and The Whole Book of Psalmes, ${ }^{41}$ published in 1640, were used as primers in early New England and contained what Reformers felt was a good introduction to the skill of reading because children could easily memorize passages. Memorization was the key at the tender years of five and six while the understanding of those passages was less important (Hall, Worlds of Wonder, 37 and Hall, "The Uses of Literacy" 24). As is common in the religious education of youth, children were told the stories of the Bible as parables for understanding real-life events, but children also understood their biblical connections. Even before they understood the meanings, and as a directive of the 1642 school law, children were familiar with the Word of God and could recite it at will as testament to their literacy skills. Their association between the world they lived in and the biblical reference for their world was innately familiar because of their early education with these religious texts. Hall cites Samuel Goodrich's own acknowledgement of the influence these texts had: "Looking back upon his own immersion ... Goodrich realized that he could not read or write without invoking in some manner the key motifs and narrative style of the Bible. His imagination was founded on a language he had learned almost unconsciously" ("The Uses of Literacy” 22). Not only were early Americans educated in literacy, they were educated in religiosity as well. Goodrich's use of the same language and his continual reference to the familiar motifs of the Bible reflect how a religious language was both produced for literacy and used by literacy in reproducing their daily life: "By one route or

${ }^{41}$ For the purposes of this research, The Whole Book of Psalms will be referred to as the Bay Psalm Book because of its indigenous origins. 
another, the world view of these texts became the world view of most New Englanders" (Hall, "The Uses of Literacy” 36).

One way children were easily indoctrinated into the religiosity of their world is through the recognition of their own names, and those of their friends, as biblical figures. The most popular names of immigrants' children between 1620 and 1650, for both male and female children, were biblical names. Non-biblical names, like those referring to former and current English monarchs or royal family members, fell drastically in popularity (Hall, Worlds of Wonder, 10 and Archer 91-93). Richard Archer, Fissures in the Rock: New England in the Seventeenth Century (2001), provides a study of naming practices of immigrants in the first years of the colonies and notes that while 61.6 percent of English, male immigrants contained one of the common English names, the majority of them chose to name the first generation of New Englanders after biblical figures, dropping the percentage by nearly half in naming their firstborn sons. ${ }^{42}$ This statistic reveals not only the communities' preference for biblical names over English common names but it also establishes the use of a popular religious tradition within the colonies. It also reflects one way in which popular religious beliefs, through the use of biblical texts, infused the community and the way members employed those beliefs as part of the community. ${ }^{43}$

To reduce confusion and keep the truth, as the Old Deluder Satan Act specifies, from being "clouded and confused" Puritan texts were straightforward. Plain style was favored by Puritans ministers and community alike (Hall, Worlds of Wonder 25 and

\footnotetext{
${ }^{42}$ Archer offers a detailed account of the names for both male and female children in Appendix E (163).

${ }^{43}$ This is one example that supports Hall's point regarding the influence of the dominant religion on popular religion. It is also part of the argument made by this dissertation that religion shaped the experience of the non-religious as well as the religious in Puritan colonies.
} 
Lazenby 53). Increase Mather complimented his own father's style: "His way of Preaching was plain, aiming to shoot his Arrows not over people's heads but into their Hearts and Consciences" (Mather, "The Life and Death" 31). Historians Perry Miller and Thomas H. Johnson, The Puritans: A Sourcebook for Their Writings (1963), explain the Puritan view “... that Holy Writ needed not the profane intermingling of human embellishment ..." (666) and a child's education began as simply as a hornbook, an alphabet list of one syllable words and included the Lord's Prayer (696). The Bay Psalm Book, the first book printed in the colonies in 1640, was followed by the printing of The New England Primer in $1683 .^{44}$ These books formed the foundation of literacy for early learners and kept with the simple style favored by the Puritan community (Miller and Johnson 696-697). The New England Primer featured rhymed verses accompanied by pictures which made memorization easy, and thus the ability to answer correctly when quizzed by either parents or community leaders. Beginning with the letter A,"In Adams Fall/ We sinned All" early learners understood their alphabet in direct relationship to religious figures and parables instead of a relationship with their secular world where the letter A could have referenced an apple or the almanac. The story of Adam's fall would already have been known to the children of the Reformation even before challenged to read. In this way, we can see that popular religion, the use of biblical parables to create books, shaped the community. Their preference for the plain-style of language reemerges later with the popularity of the jeremiad sermon.

All parents, and adult members of the community were responsible for the education of young children, and most households kept the Bible, Bay Psalm Book, and

\footnotetext{
${ }^{44}$ These were the first books printed in the colonies but prior to these the first printings were of the freeman's Oath, the Pierce almanac for New England. See Duniway, Development of Freedom, 23.
} 
the catechisms in their meager library. While Puritan leaders likely had larger libraries consisting of books they brought from England, most households had these basics for reading (Wall 9; Demos, A Little Commonwealth 12-13; Hall, Worlds of Wonder 34; Hall, "The Uses of Literacy" 27). Even before the burgeoning print industry began, ministers were instrumental in getting reading materials into the hands of the community. There is evidence of churches in several towns purchasing and distributing catechisms. Hall notes several measures for spreading reading material were effective: bequeathing books in wills; ministers handing out copies of their sermons, such as Richard Mather who copied his sermon, A Farewell Exhortation, for each of his congregation members; and the establishment of libraries, both large and small. Yet, "The most persistent agencies that handed out free books was the government of Massachusetts and Connecticut," (Hall, Worlds of Wonder 44) beginning with a collection of the law codes. Massachusetts and Connecticut handed out free books and used tax money to print law codes and distribute to every town particularly for the use in conjunction with public readings (Hall, Worlds of Wonder 44-45). Also known as "publishing," a town would frequently have a public reading of the law codes, proclamations, fasting day announcements, and sermons.

This tradition of reading aloud things of the utmost importance reinforced two established edicts in the Puritan community: the power in the written word and the symbiotic nature of reading, hearing, and seeing. A passage in the book of Revelations, written by John the Apostle, emphasizes the connection between these three things because John witnessed the angel sent by Christ, and could testify to the things he heard and saw, allowing him to speak with authority when he says "Blessed is he who reads 
and those who hear the words of this prophecy" (Rev 1:3). Because John saw the messenger from Jesus, he bears witness to the authority of the words that are read and heard. While seemingly unimportant, this connection between reading, hearing, and seeing becomes extremely important at the gallows later in this dissertation.

Not only were the readers of early America encouraged to read, and their literacy made paramount, they were also instructed on how to read in order to get the most out of the hearing the Word. “The Bible wasn't just a book, the Scripture wasn't just words. The Bible was the voice of God and people heard the Word" (Hall, Worlds of Wonder 24). The act of hearing and the act of reading were one in the same for Puritan households. Holy texts were read out loud in the home and the very process of learning to read began with being read to. But, hearing had another meaning: hearing was equated with understanding. Thomas Foxcroft was adamant about the need for reading in his sermon, Cleansing Our Way in Youth (1719): "The word Written and Preacht is the ordinary Medium of Conversion and Sanctification. Now in order to obtain these Benefits by the Word, it is requisite, that Persons be diligent in Reading and Hearing of it" (176). The burden of understanding God's Word was on the individual: "The meaning of the Word was evident to those who felt its truthfulness within, as in their 'hearts.' To understand the Word required 'faithful' hearing, a faithfulness that grace made possible" (Hall, Worlds of Wonder 25). Through God's redeeming grace one is able to understand the truth of God's Word unmediated by an intercessor. The reverse being true as well: if one struggled to hear the truth it was evidence not of confusion in the text but confusion or refusal in the heart of the listener. 
Hall shows how the bridge between the written Word, as ephemeral, is made permanent in the thoughts of young readers in the New England Primer:

Give ear my Children to my words, whom God hath dearly bought, Lay upon his Laws within your heart, and print them in your thought (qtd. in Hall, Worlds of Wonder 39). These passages function to eliminate the possibility of mediation of words that held the “perfect Truth" of God's Word. In keeping with the Protestant vernacular tradition, they supposed that to read was to hear, to hear was to see, and to see was to receive the truth (or light) communicated to the inner self, the heart" (Hall, Worlds of Wonder 39, italics mine). Scripture was the living speech of God, and therefore heard, whether read or spoken: Scripture acts directly on its reader/hearer to ensure God's truth. "In using these texts to learn how to read, children in New England also absorbed the elements of the religious system" (Hall, Worlds of Wonder 38). Reading was encouraged because it brought one closer to God to be sure of what they were hearing. "More, these people learned to read these books intensively — to regard them with awe, and to return to them repeatedly" (Hall, Worlds of Wonder 43). Spoken sermons were treated as truth because they contained the Scripture and were written by God's magistrates on earth, and so too would the printing of sermons be. Once the printing industry began, readers in New England would have a wealth of sermons to add to their faith-inspiring collection of materials.

Though the Bible was a commodity, printed and sold like any other book, for the readers of early America "It was priceless, though you found it in the marketplace; it was 
timeless, though a printer may have dated an edition; it was living, though its matter was mere ink and paper" (Hall, Worlds of Wonder 24). Because of this belief in God's Word as the living word and because ministers established themselves as God's magistrates on earth, sermons and the scripture they contained were accepted with the same reverence afforded to the Bible. "How the Bible appeared as the living Word of God would affect how other books were represented, and how they were read" (Hall, Worlds of Wonder 24). Though the early ministers were well educated in the art of writing and rhetoric, they held to the belief that embellishment was not needed (Miller and Johnson 665-667) but, their classical training would prove useful to the establishment of a print culture that extended their reach from the pulpit. "Printed sermons in the plain style continued to impress their readers by being nearly like the Bible" (Hall, Worlds of Wonder 32). This plain, familiar language would make the sermons printed in early America both accessible and understandable for a community that relied on the minister's presence, the centralized meetinghouse, and God's Word to help them make sense of the strange events in the vast, wilderness of their home and the wilderness of their souls.

\section{The American Jeremiad as Crime Literature}

Many, if not most, of the sermons produced in the early years of the Massachusetts Bay colony by Richard Mather, John Cotton, and John Winthrop, whom I term Puritan fathers, centered on assurances of election, the establishment and maintaining of pure churches, and a general concern for the welfare of the colony and the troubles they faced. Elliott finds that their sermons contained metaphors and imagery of a holy quest: "a sacred errand that they were leading for God into the howling and barren wilderness ...the dream that God had commissioned this small band of colonists to fulfill 
the special mission of creating a new Jerusalem in a barbarous land" (4-5). The writing and delivering of these sermons helped them and their congregations make sense of their world and renewed their faith in their mission.

Sermons also performed a particular function for calling the colony together for days of humiliation or days of thanksgiving. ${ }^{45}$ Thanksgiving and humiliation days were determined by providence and not by the colony. These particular days, and the sermons that accompanied them, called the community together in a particular type of communal confession and collective atonement in order to account for wrongs the colony had committed and to ask for God's forgiveness in order to assuage whatever plagued the colonial body. "Afflictions do not just happen, they are, literally, acts of God" and God's chosen people can interpret these signs and assuage the wrath (Miller, The New England Mind 23). Miller draws attention to the fact that there is a distinction between the physical afflictions and sin in the call to humiliation: "There is implicit recognition of a causal sequence: the sins exist, the disease breaks out; the sins are reformed, the disease is cured" (The New England Mind 27). The process of reforming the sins had to be a public humiliation by taking what ails the community and converting it into a communal resolution. Since every individual in the colony was not a church member, nor did they even fall under the very flexible category of "half-way," contemporary inquiries question how these days of humiliation and thanksgiving were so successful? While we cannot measure the crowd response to such events, we can consider the effect of a national

\footnotetext{
${ }^{45}$ Perry Miller designates the first of these days of thanksgiving, in 1621 at Plymouth, as being the origin of our own American holiday of Thanksgiving. Yet, Miller says that the idea of a designated day every year as a day of thanksgiving is very anti-Puritan thinking. "For the Puritan mind, to fix thanksgiving to a mechanical revolution of the calendar would be folly: who can say that in November there will be that for which thanks should be uttered rather than lamentation?" (The New England Mind 19).
} 
covenant as a catalyst for the success. The national covenant ensured the community's willing participation because they saw the benefit of solidarity as means to success. ${ }^{46}$ Communal expiation is part of the necessary process for success in the colony. Cooperation would have meant being part of the greater good of the people, a concept that would become part of America's national thread by the end of the next century. ${ }^{47}$

This system of humiliation for afflictions and thanksgiving as rejoicing for answered prayers is unique to the American experience: "The success of these early fasts left upon the New England mind an impression in which we may locate minute beginnings of adaptation to an American situation" (Miller, The New England Mind 1920). These early successful humiliations took place within the churches and were a great relief to the community. Andrew R. Murphy notes that many cultures have a tradition of the jeremiad form (6) but the American jeremiad is American because it is linked to a "larger, sacred story tied intimately to the particularities of the nation's origin and development" and compares it to what many call a "civil religion" (10), thus connecting religion to politics because of the original intent by religious founders of America to create a place of "God's chosen people." The basis for the jeremiad is drawn from the Biblical prophet Jeremiah who claimed that all the adversities and tragedies of the time were caused by the broken covenant. Puritan ministers adopted this same structure in their own writings as an instrument of warning to their own Israel. The essence of the jeremiad is the fracturing of the covenant and the apocalyptic future in store for them.

\footnotetext{
${ }^{46}$ For a larger discussion of church polity and social theory as a national or external covenant, see Miller, The New England Mind 21-24.

${ }^{47}$ The effectiveness of humiliation and thanksgiving days eventually led to the Massachusetts General Court taking over for the church, in the interest of the whole community, the responsibility of "summoning to repentance" the entire colony (Miller, The New England Mind 20). The process remained largely unchanged for nearly 15 years.
} 
The purpose of the jeremiad remains the same: a call for action by the community to avert further punishment. Literary and cultural critic, Sacvan Bercovitch argues "In explicit opposition to the traditional mode, it (the American jeremiad) inverts the doctrine of vengeance into a promise of ultimate success, affirming to the world, and despite the world, the inviolability of the colonial cause" (7). While the jeremiad did not minimize God's pending wrath, according to Bercovitch, it turned the threat of destruction into a correction by God as a sign of His love for His chosen people: the punishment confirms His promise (8-9). Thus, the jeremiad, as an American convention, can be traced back to the later part of the 1640s. Miller traces the evolution of the form: "For the second and third generations of New England, the jeremiad was the only appropriate convention because it made sense out of their unique experience" (The New England Mind 31). These sermons not only brought comfort, the community relied on these sermons to identify sin and for ministers to tell them how to atone for it. also describes the purpose of the jeremiad as a "ritual designed to join social criticism to spiritual renewal, public to private identity" (Bercovitch xi). These sermons functioned as didactic tools, and became even more powerful when ministers deliver them in conjunction with a crime.

Miller marks October 19, 1652 as a crucial moment in American history: for the first time, the provoking of sins was listed among the reasons for humiliation, "the worldly mindedness, oppression, \& hardheartedness feared to be among us" (qtd. in Miller, The New England Mind 28). Miller claims this reflects a shift from the external to the internal, "instead of looking upon sensible deprivations as retributions for crimes already committed, they confessed that their consciousness of sinfulness was itself a curse on the body politic" (Miller, The New England Mind 28). This shift would solidify over the next 
ten years and humiliations drew recitations of spiritual failures and moral deficiencies instead of rains and crop pests. This shift in emphasis may have gone unrecognized at the time but it had a lasting effect on the way corruption was viewed: "The subjective preempted the objective: a universal anxiety and insecurity had become no longer something which, being caused, could be allayed by appropriate action, but rather something so chronic that society could do nothing except suffer-and perpetually condemn itself” (Miller, The New England Mind 28).

Perpetual condemnation suits the innate anxiousness that comes from the intense self-reflection encouraged by the very theology of Puritanism and the constant insecurity of their own election and fear of their own sinfulness. Yet, it would be others' sinfulness that would solidify the development of an American literary form: the jeremiad. As Miller points out, the fear of something chronic at the heart of the colony locates the threat within rather than an external one and becomes the focus of the minister's call for humiliation. The internal threat that manifested itself in the late 1600s and ended up in the body of every jeremiad was sin. It would be the threat of sin that would induce ministers to create some of the most inflammatory jeremiads in response to capital crimes.

Since Puritans believed that the Scripture held all things necessary to salvation, and they were intimately aware of how salvation could become a product of an intermediary like the Catholic Church, firm-handed governance was applied to the printing presses. Texts printed in the colonies had to meet the strict standard of reaffirming God's Word, qualifying very few people to be authors. This demanded a steady governing over the printing business in the colonies. The Puritan legitimization of 
ministers as being God's men, and therefore able to construct godly texts for use in the community, solidified the marriage of literacy to religion for the new generation of colonial Puritans. Ministers set themselves apart from their congregation through claims "that they were 'called' by God to serve as his 'ambassadors' on earth... they were the 'means of grace' by which the messages of the gospel was transmitted to the chosen... to deny the means of grace, to resist or to rebel against their preaching, amounted to denying God himself" (Hall, Worlds of Wonder 12). Neuman argues that much of the sermon culture of Puritan New England was idiosyncratic, such as the belief in sola scriptura (by scripture alone), and yet they still prolifically produced sermons. Neuman claims these sermons fall in the category of the Puritan belief that individuals must still seek 'ordinary means' to salvation (12) and these ministers provided those means. Puritan lay men and women understood this ministerial language. They learned from both the spoken and the written word. But, as Hall explains, "[Yet] the ways they viewed the world were sustained by print culture..." Hall argues that ministers, through print mediums, were able to reinforce their sermon messages with the average lay person (Worlds of Wonder 70).

While the Protestant Reformation shed the hierarchy of the Church, early Americans still upheld the difference between the clergy and lay men and women. "In declaring that their 'office' entitled them deference, the ministers took advantage of assumptions about 'order' that everyone acknowledged” (Hall, Worlds of Wonder 13). Though the community recognized the minister and his relationship with God, early Puritans also believed that ministers responded to the highest authority, as Hall explains, "... the authority of ministers was held in check by a premise they [the congregation] 
themselves affirmed, that any version of the "truth" whether learned or unlearned, must conform to the Word of God" (Hall, Worlds of Wonder 20). Ministers, through affirmation of their godly association and their extensive education, became the most prolific authors in the colonies.

It was not just the minister's authority over the printing press nor their position as leaders in the community that made them so popular. Their popularity in the pulpit translated into printable material. Early colonial readers would turn to the printed sermon as an additional means for understanding their world. Neuman argues that a theory of language developed and the production of sermons as means for assisting in understanding the divine language of the scripture. Sermons, Neuman explains, were "The narrative of a simple, untroubled exegetical process - whether the translation of scripture into the vernacular or the plain-style explication of the literal sense-is a necessary doctrinal fiction" (151). By necessity, and by providing the "ordinary means to salvation,' ministers constructed sermons to create "a bridge between human and divine articulation" (Neuman 152). The familiar language of Puritan sermons made them popular sources for both reading and for stabilizing their lives. "Spoken sermons were as sacred as the printed page" and people frequently referred to sermons when speaking of their own faith rather than about books or the Bible (Hall, Worlds of Wonder 42) because the divine language made literal sense to them. This is a difficult concept for us as modern readers to understand because it is difficult to construct the lived experience. "Central to the lived experience of piety, sermon culture dictates not only habits of thought but habits of interpretation and expression as well" (Neuman 6). Part of what the average colonist connected to in the sermons is lost in our contemporary perspective. 
Though copies of sermons written by Puritan ministers account for much of the way we conceive of early colonial history, not all of those sermons made their way into the homes of colonists. What concerns us here are those sermons which did make their way through the tight-grip of those appointed to oversee the printing of texts. True to the belief that the Bible was God's living Word, and in the vernacular tradition, Puritans understood reading as hearing and hearing as seeing, and seeing meant receiving the truth in your heart. "What was printed was to be received as though it had been spoken, and therefore as the truth" (Hall, Worlds of Wonder 38-39). The authority of what was written governed what was printed and helps us to understand the importance of the texts that made it to print because their tangible presence had both an immediate and a lasting effect on the community. This dissertation will return to the affect these sermons had on the gallows crowd when analyzing the language used in the sermon delivered in conjunction with the crime of concealment.

No other occasion provided a subject matter more popular than the occasion of an execution. The guilt of a criminal convicted by the court was woven together with the doctrine of sin to flood early New England communities with crime literature that held the power of God's Word and extended the influence of the ministers beyond their pulpits. On the occasion of a crime, gallows sermons "reflected a cohesive and disciplined Puritan culture" and the ministers served as "spokesmen for the community as a whole" (Cohen 248). For the early Puritan ministers, crime literature provided a means of interpreting the sin of the criminal and a venue for expounding on the sins of the community. With God's magistrates as the approving authority, printed execution sermons were a means of connecting crime and sin and combined with the gallows drama 
to become the most popular form of crime literature in the colonies. From 1674 to 1860 , pamphlets, books, and broadsides relating to capital crimes and containing sermons and execution narratives were prolifically printed (Cohen ix). In 1674 Samuel Danforth published The Cry of Sodom Enquired Into, making it the first of 29 execution sermons produced in New England. This development of interest in crime literature in Puritan New England provided ministers with an opportunistic venue to extend their influence outside of the church. England had its own crime genre, which was very different from the crime literature that developed in New England. Gallows literature in England consisted of crime accounts, trial reports, hanging ballads, murder plays, rogue biographies, and conversion narratives. ${ }^{48}$ While these crime accounts and trial reports tended to be more factual, the newspapers and broadsides tended to be more theatrical and dramatic (Cohen 41$).{ }^{49}$ The latter group never made its way across the ocean and left New England open to creating its own popular crime genre. Prior to 1800, 203 pieces of gallows literature were published in the Americas: 71 execution sermons and 121 pieces of supplementary material, including narratives (written with second-hand information) ${ }^{50}$ and "confessions" or "dying words" from the criminals themselves. Thanks to the structure of the literary convention of the jeremiad, execution sermons were the most popular form of crime literature through the first decades of eighteenth-century Puritan New England (Bosco "Checklist" 82). "A literary form does not come into flower unless it answers some deep necessity of the time and the place. As a drama was the ideal

\footnotetext{
${ }^{48}$ In conversion narratives, criminals expounded on the connection between their sinful behavior and their crime. Unlike declaration or dying words, the criminal made a lengthy confession to the crime. In the end, the criminal made a lengthy plea to God for forgiveness.

${ }^{49}$ While England also employed ministers to work closely with criminals to produce gallows literature, in the early years of public execution Puritan ministers appointed themselves solely responsible for acquiring, writing, overseeing the publishing, and occasionally even the distribution of execution texts.

${ }^{50}$ The missing numbers reference 11 gallows poems.
} 
articulation of Elizabethan London, the jeremiad was for the tiny communities of New England" (Miller, The New England Mind 52). Sin was a preoccupation of the Puritan minister's mind and the jeremiad was the medium for expressing their anxieties.

Crime overwhelmingly provided a good source of material for print culture in early America in part because crime afforded ministers the evidence of guilt, as established by their conviction in court, needed to construct a sermon which expounded on the sins of the community. The popularity of the printed sermon matched the popularity of the minister's success in the pulpit. In turn, print culture itself became the medium ministers used for extending their religious influence in the community. Daniel Cohen, in Pillars of Salt Monuments of Grace: New England Crime Literature and the Origins of American Print Culture, 1674-1860 (1993), traces the popularity of crime literature and provides an exceptional account of the ministers' role in the creation and distribution of sermons as popular culture. ${ }^{51}$ Cotton Mather remarked in his diary that the sale of his first execution sermon of 1717 reached nearly one thousand copies in five days. Later that year, another of Mather's execution sermons sold twelve hundred copies, a number that would indicate a copy for one in every ten members of the community. ${ }^{52}$ Thus execution sermons were the most popular form of crime literature through the first decades of eighteenth-century Puritan New England (Bosco 82).

While England experienced a growing liberty in the content and subject matter of its publications in the mid to late 1600s, Massachusetts was strictly guarded (Ford 59; Cohen, Pillars of Salt, 46; and Hall, Worlds of Wonder, 47). Though there is no record of

\footnotetext{
${ }^{51}$ Cohen uses the term "popular culture" as way of indicating the print genre that was designed to reach an extensive audience and not material designed to reach a specific audience (xi).

${ }^{52}$ Several scholars make this same claim: Cohen, Pillars of Salt 6; Seay 39. Lazenby 51.
} 
formal censorship in the early years of printing, court records and diaries reveal the "penalty for outspoken and persistent freedom in differing from the majority of the magistrates and ministers" was inability to attain authorization for printing (Duniway 39). The products of the printing press reveal a strong adherence to the desires of the Puritan ministers. What could pass for sale in the cheap shops of London Bridge would have "called down trouble upon the shopkeeper" of Boston (Ford 49). Aside from the minster's involvement in the production of crime literature, New England's crime genre was also unique in both form and delivery. ${ }^{53}$ Gallows literature in England consisted of crime accounts, trial reports, hanging ballads, murder plays, rogue biographies, and conversion narratives. While these crime accounts and trial reports tended to be more factual, the newspapers and broadsides tended to be more theatrical and dramatic (Cohen 41). More importantly, not only is the addition of criminal narratives unique to New England, Cohen describes them as "an innovation of the New England Puritans" (3). Sermons addressing the sins of the whole community moves from election and fast day sermons delivered in the center of town to the meetinghouse, and then at the gallows to address the sins of an individual prior to an execution. The Puritan ministers' plain speaking and minimal use of doctrinal language were well received by the average colonist (Hall, Worlds of Wonder, 55- 56; Lazenby 53). Undoubtedly, it was the occasion for the sermon which also contributed to its popularity. Danforth's execution sermon in 1674 exhorting the sins of Benjamin Goad, who had been recently convicted of bestiality, was published at a time when only three presses operated in all of New England (Cohen, Pillars of Salt 46). By 1719 the printing industry had grown significantly: Boston had

\footnotetext{
${ }^{53}$ This idea is expressed by numerous scholars. See Cohen, Pillars of Salt, 3; Bosco, Ronald A. "Lectures at the Pillory: The early American Execution Sermon. " American Quarterly 30. 2 (1978): 156-176.
} 
five presses and nineteen bookshops. Some scholars argue that the ministers of the time were simply trying to capitalize on a popular interest. ${ }^{54}$ Though this may be true, ministers rarely received any monetary profit from the sale of their works. In fact, ministers earned no royalties from the sale of execution sermons since the system of publishing, as Hall describes, was one where the printer himself was burdened with the cost in the hopes of selling numerous, cheap copies (Cohen, Pillars of Salt 5; Hall, World of Wonder 47). Instead, ministers focused on the moral profit that came with the additional venue both the text and the hanging offered for more vitriolic addresses. Yet gallows literature also made for fantastic drama. Combined with the public death of a member of the community, execution literature provided entertainment and created endless fascination and, at times, self-reflection for the community of Puritans (Williams, Pillars of Salt 5; Cohen, Pillars of Salt 84). Narratives or "dying speeches" were even more popular than the sermons or the hangings, and had the ability, in print, to leave a more lasting impression on the readers who were asked to read the printed material carefully. For example, the preface published along with Thomas Foxcroft's execution sermon states, "I have two things to request of you before you read this sermon... The one is, that you would pray over it before you read it; that God would accompany the reading of it with effectual operation of his spirit, without which the most powerful words man can use, will be but as a dead letter, altogether ineffectual to convert and sanctify you. The other is, that after you have read it, you would allow yourself time to think on what you have read, and enter into a solemn debate with your own soul thereupon" ("Lessons

\footnotetext{
${ }^{54}$ Williams and Cohen both state that ministers were aware of how popular the condemned criminals were to the community and suggest that their popularity spurred the writing and publishing of execution discourses. Williams goes as far as categorizing narratives as commodities "shaped by the demands of the consumers" Williams, Pillars of Salt 12; Cohen, Pillars of Salt 84.
} 
of caution to young sinners" 3 ). The dying speeches were thought to have a cathartic effect. Coupled with the sight of a criminal on the gallows, and hearing it read aloud, the printed speech would have an even greater effect on the crowd because of the symbiotic nature of seeing, hearing, and reading for the early Puritan.

These three factors make an execution a perfect venue for delivering messages exhorting the Puritan doctrine: how the community's covenant with God makes the sin of one, the sin of all; the scriptural counterpart to capital crimes as justification for the punishment; and the need for self-examination to prevent these crimes. In addition, the publication of execution sermons and narratives combined with the visual image of the death of the sinner by the gallows attendee gives the minister's message an enduring impression. Though broadsides were easier and quicker to produce in time for a hanging, sermons were the substance of the crime literature genre. These factors make execution sermons and narratives in the hands of the community some of the most powerful discourses of the Puritan era.

Bosco points out that the very concept of the formation of the colonies was that the community functioned as "one" in a covenant with God ("Lectures" 163). That covenant, as described earlier, is the promise of God to all mankind through Abraham: And I will establish my covenant between me and thee and thy seed after thee in their generations for an everlasting covenant, to be a God unto thee, and to thy seed after thee. And I will give unto thee, and to thy seed after thee, the land wherein thou art a stranger, all the land of Canaan, for an everlasting possession; and I will be their God. And God said unto Abraham, Thou shalt keep my covenant therefore, thou, and thy seed after thee in their generations. This [is] my 
covenant, which ye shall keep, between me and you and thy seed after thee .... (Genesis 17:7-10)

The concept of the community as a singular entity is also derived directly from biblical scripture. Frequently the church is termed as the body, where all members are a part of the body. The use of the term body is one the Puritan community would have seen as truth because of the scripture that defined it. The words of the apostle Paul:

For as the body is one, and hath many members, and all the members of that one body, being many, are one body ... For by one Spirit are we all baptized into one body ... For the body is not one member, but many ... But now hath God set the members every one of them in the body, as it hath pleased him ... That there should be no schism in the body; but the members should have the same care one for another. And whether one member suffer, all the members suffer with it; or one member be honoured, all the members rejoice with it. (1 Corinthians 12:1227)

So here is the basis, in a simple and summarized form, for the formation of a Puritan community whose members hold themselves as a collective body of one in a covenant with God. Because the community functioned as one, the ministers use the criminal to serve as a cathartic expression of the entire colony.

The punishment of capital crimes by death makes an ideal place for the sermons because of the close relationship between capital crimes and biblical scripture. As explained in the previous chapter, Puritan colonies used biblical scripture for the formation of their legal statutes. Though the statutes could have been the same in England, it was the use of scripture to justify the law that makes it uniquely Puritan. 
"Statutes imposing the death penalty were characterized by a closer fidelity to biblical law than almost any other category of legislation in seventeenth-century Massachusetts" and scriptural precedents were not necessarily used to find a criminal guilty, but rather to justify a capital punishment (Cohen, Pillars of Salt 102-103). Along with murder, sexual crimes made for the most popular of execution sermons. The first execution sermon published in Boston was for the crime of bestiality. ${ }^{55}$ Because capital crimes, including sexual crimes, were justified in the colonies with biblical scripture, and the scripture being the divine holy text, the sermons, being holy texts delivered through God's ambassadors, preached at the execution drew on all of the prevailing connection to an individual's spirituality and relationship with God,“... among conscientious Puritans, there could hardly be a more effective bulwark of judicial severity than that provided by Holy writ ... as offenses against the law of Scripture and its divine author" (Cohen, Pillars of Salt 102). The power of this connection to an epistemologically, or doctrinalbased, spiritual existence was intended to lead the listener/witness to a self-reflection. Because ministers were the sole authors of the execution sermons, the message was seen as God's Word to the community.

Printed execution sermons followed the format of most Puritan sermons and would have been very familiar to the readers of the community. Since the publication of the execution sermon was an attempt to reach a greater audience than that of the church congregation (Minnick 80), the message would have been made as clear as possible. In the sermons, ministers would explain how the criminal's wickedness led them to their

\footnotetext{
${ }^{55}$ Cohen notes that Danforth used the case against Benjamin Goad, convicted of bestiality, as an example of how "the unclean" implicated an entire community and how the community would suffer for the sin "If we will not pronounce such a Villain Accursed, we must be content to bear the Curse our selves" (Pillars of Salt 103).
} 
crime, warned others of doing the same and how their behavior could lead them on the same path, and then justified the punishment of the criminal: the crime itself simply provided the narrative for the sermon. Ministers spent equal time and length on an explanation of how the crime was an affront to the national covenant (all wickedness was an affront), how the judgment and punishment matched the crime (biblical justification for capital crimes), and how mankind was at risk for more of God's wrath if the community did not take action now and stop further affronts later (that we are saved from sin by God). Thus, execution sermons were an ideal forum for delivering these types of warnings to the community. Nothing is better for illuminating God's judgment on the wicked than an occasion of punishment by death.

The first printed execution sermons were published in their entirety and resembled the standard Puritan sermon. Even with the addition of supplementary materials later, seventeenth and eighteenth-century crime literature focused primarily on the sermon. In the earlier years of the colonies, the sermons were made available in print within a few days. In some cases, ministers were rushed to produce the sermon and subsequent execution materials. Sermons for criminals were typically delivered on Sunday morning before the execution, though sometimes they were delivered immediately before. Ministers would evoke metaphors in their instructions which involved an individual's senses to best receive the message. Metaphors urged readers to "chew" to "taste" or to "suck" the Word of God. ${ }^{56}$ The ingesting of the Scripture was familiar to readers who viewed the Bible as something that was living and breathing and infused with the Spirit of God. To ingest the Word meant to digest it and to absorb the

${ }^{56}$ See Hall's references, Worlds of Wonder, 27-29, to ministers who repeatedly use the metaphor of eating the Scripture. 
nutrients from it. "Scripture acts on its readers to ensure the truth of what they learned" (Hall, Worlds of Wonder 24) and the way Scripture "acts" on its reader was a linguistic use of metaphor. While understanding the Puritan choice of metaphors to elucidate their point about the sins of the community is important, it is also to view this language and use of metaphor in conjunction with their use at the gallows. Nothing is better for illuminating God's judgment on the wicked than an occasion of punishment by death of a criminal that received their conviction in court.

The punishment of capital crimes by death makes an ideal place for the sermons because of the close relationship between capital crimes and biblical scripture. As explained in the first chapter of this dissertation, Puritan colonies used biblical scripture for the formation of their legal statutes. Though the statutes could have been the same in England, it was the use of scripture to justify the law that makes it uniquely Puritan. Cohen points out that "Statutes imposing the death penalty were characterized by a closer fidelity to biblical law than almost any other category of legislation in seventeenthcentury Massachusetts" (102). Cohen also points out that scriptural precedents were not necessarily used to find a criminal guilty, but rather to justify a capital punishment (102103). It is also necessary to point out, once again, the inclusion of sexual crimes into colonial statutes for capital crimes. Along with murder, sexual crimes made for the most popular of execution sermons. The first execution sermon published in Boston was for the crime of bestiality. ${ }^{57}$ Because capital crimes, including sexual crimes, were justified in the colonies with biblical scripture, and the scripture being the divine holy text, the

\footnotetext{
${ }^{57}$ Cohen notes that Danforth used the case against Benjamin Goad, convicted of bestiality, as an example of how "the unclean" implicated an entire community and how the community would suffer for the sin "If we will not pronounce such a Villain Accursed, we must be content to bear the Curse our selves."
} 
sermons, being holy texts delivered through God's ambassadors, preached at the execution drew on all of the prevailing connection to an individual's spirituality and relationship with God. Cohen further explains this concept by stating "among conscientious Puritans, there could hardly be a more effective bulwark of judicial severity than that provided by Holy writ ... as offenses against the law of Scripture and its divine author" (102). The power of this connection to an epistemologically, or doctrinal-based, spiritual existence was intended to lead the listener/witness to a self-reflection.

Miller questions why the Puritan ministers preach self-condemnation repeatedly to a people who conquered wilderness, sea, and savages on the foundation that they were "God's chosen" (46). The use of the jeremiad form in execution sermons then makes sense; the message was being delivered to those outside the church. Furthermore, the use of the jeremiad perhaps makes unequivocal sense when used in the execution sermon and supplemented by a narrative: together, the sermon assigns the blame and asks for repentance from the guilty and the narrative functions to relieve the community of that guilt and place it on the criminal instead.

After utilizing their election day sermons, ministers relied on the printing presses to create hundreds of copies each year. "And so ministers seized their advantage, a magnificent pulpit from which an entire society might be exhorted, and methodically reminded New England of what God expected of it" (Middlekauf 114). While scholars note the decline of the election and fasting day sermons, execution sermons and narratives were just coming into their own popularity. Previous occasions, election days and days of fasting, were typically sanctioned by the General Court; executions were venues where ministers were expected to be present but were under no guidance from 
secular elites to perform a service or deliver a sermon. Execution sermons were therefore free-reign for ministers to deliver an ungoverned message. Puritan ministers, exerting their authority over the few printing presses in the colony, flooded the newly developed publishing market with execution sermons.

Not only did the execution ritual, of sermon and scaffold excite the community, the printed materials kept the minister's message fresh in the minds of the colony and created a permanency reinforced by the image of the criminal on the gallows. In fact, Cotton Mather said, "Sermons preached are like showers of rain that water for an instant, but sermons printed are like snow that lies longer on the earth" (qtd. in Hanging Between Heaven and Earth 26). Execution sermons, and later the criminal narratives, were an ideal form of family reading (Cohen 5). As shown earlier in this chapter, these texts were instruments of literacy that played on the intimate connection between reading and spiritual life. It is the power and the permanence of the jeremiad itself that makes it such a useful tool.

More importantly, the connection between the criminal's guilt as the alleviation of guilt for the community is reinforced by the sermon but more so by the narrative in printed form in the hands of the gallows crowd. The execution sermons and narratives of colonial New England varied based on the nature of the crime and the purpose of the sermon and narrative. For a community who saw God manifested in their everyday life, these sermons explained not only the sins of the criminal but the sins of all and offered a moment of cathartic expression for the entire colony. But more than that, these texts, as both spoken sermons and written Godly texts, possessed the power to connect the 
symbiotic nature of hearing, reading, and knowing as means of salvation. A power that was connected to the minister's own power within the community.

While the relationship between ministerial power and print culture may seems obvious, what is less obvious is the way that the power of language functioned in the community. If the early colonists, whether they were church members or not, used these texts to make sense of their world then these texts functioned outside of their overtly intended use as crime literature. The development of literacy and literary practices not only influenced colonists in the religious system but also influenced the way they made sense of events and, at a higher level, in the way they viewed themselves and themselves in their world. The print culture was looped back to Scripture and achieved a power of its own, even outside the pulpit. "The very process of becoming literate ... conveyed to would be readers the authority of print, an authority that rested on the equivalence of speech and writing" (Hall, Worlds of Wonder 38). The result was that printed texts achieved power and permanence within the culture. Hall discusses the permanency of symbolic language by saying, "The archetypal source was Scripture. Its figures, tropes, and stories were echoed and reechoed in almost every kind of text that people came in contact with ... It even overrode the gap that may have separated readers and nonreaders, because it lent itself to visual presentation" (Hall, Worlds of Wonder 69).

Understanding how literacy functioned at the heart of the cultural practice of execution helps us to understand what the community thought and felt about not only crime in their community but in the way they viewed each other in their daily colonial life. The Puritan community's literacy was inherently a religious education as well. Criminal sermons were part of the community's literary toolkit for building an orderly 
system of values. Though the sermons and accompanying material established a literary genre unique to early America, other differences within the genre exist. Discerning these differences, particularly those sermons at the crime of women convicted of infanticide show the underlying cultural differences between men and women. In the next chapter, this dissertation investigates the symbolic language used in these execution sermons. This dissertation will also specifically examine those execution sermons written and delivered at the gallows for a woman convicted under the concealment statute. The ministers' use of metaphor, symbolic language, and his choice of biblical scripture focus on a woman's body, and not her crime; this shaped the way the community views women and the way the community assigns value to women's lives. Concealment, as explored in the previous chapter, was seen as a willful deception and a fraudulent practice that reflected the immoral character of a person. The next chapter will discuss the anxious environment of the colony and the many challenges they faced in the wilderness that contributed to the changing structure of the sermons used to discuss sin and pollution of the colony. Chapter four will focus on these sermons which are also accompanied by a criminal narrative, purportedly "taken from the mouth of" the criminal herself, as her acknowledgement of her immoral character. Outside of conversion narratives, concealment narratives do not reflect the acceptance of guilt for the crime but the acknowledgement of a woman's guilty nature instead. 
CHAPTER THREE

SEXUALIZING CRIME:

CONCEALMENT IN MASSACHUSETTS

"Give ear my children to my words, whom God hath dearly brought:

Lay up his laws within your heart, and print them in your thoughts."

John Rodgers-The New England Primer Improved

In seventeenth-century New England, a sermon preached at the execution of a criminal in the center of town would have served the purpose of ministering to the community about the sins more than the crime of the convicted: making the sermon a very public, very political discourse. With more people at the gallows than in the pews, ministers were able to deliver their message to a larger, more diverse audience. The jeremiad, a powerful rhetorical tool used to address the fracture of the colony's covenant with God, moves from the pulpit to the center of town to sermonize at the hanging of a woman for concealing the death of her infant. This moves the jeremiad from the meetinghouse and locates itself at both the physical and metaphorical center of the town while also relocating the message of sin from the body of the community to the body of the convicted. The purpose of the rhetorical structure of the jeremiad was to lead the congregation to atonement for what the minister identified as the causes of God's wrath, and this atonement required public humiliation: "Public humiliation was the only sure 
method of relieving public misfortune, not only because it sought for mercy, but because it translated misfortune into a common resolution to do something about it" (Miller, The New England Mind 24). If Miller's interpretation is correct, then what place does a jeremiad have at the execution of a woman for concealment $?^{58}$

The first chapter of this dissertation argued that the incorporation of the 1624 statute for concealment by Massachusetts Bay was part of the founders' efforts to form a legal system that would help them establish their godly community. The second chapter considered the importance of literacy and the intimate relationship between becoming literate and becoming religious to show how literacy and printed materials made the body politic religious without being church members or under the direct influence of church leadership. The many anxieties felt by the ministers and by the colony in chapter one focused on the uniqueness of the Massachusetts Bay community in their struggle to keep their covenant while establishing their "city on a hill." The way these ministers expressed themselves and their concerns to the colony resulted in the creation of the jeremiad and chapter two analyzed this rhetorical form as a uniquely American convention used to sermonize at the gallows for capital crimes. This chapter will begin with a discussion of sexual crimes as gendered crimes. This discussion frames the conclusion of this dissertation which argues that the act of concealment can be seen as a particularly offensive one within a community that searched out secrecy, valued confession, and condemned sin as crime. This chapter begins with a discussion of female felons to contextualize female crime in Puritan New England. I examine the language used in the 1624 statute for concealment to suggest that the act of concealment is viewed as a moral

\footnotetext{
${ }^{58}$ For clarification, I use the term concealment to mean the crime and the italicized concealment to mean the act of concealing.
} 
issue in the courts. I then examine the symbolic language involving secrecy, hiding, and sin used in one example of crime literature to suggest that a woman convicted of concealment posed a particular threat to the leaders of the Puritan colony. This leads me to argue that her postpartum body was a site of sexual knowledge and represented the power to conceal from the church and the community her sexual behavior, her partner, her pregnancy, and her control over reproduction.

Women were believed to have a natural connection to corruption particularly because of their association with sexual behavior. Richard Godbeer, in Sexual Revolution in Early America (2002), plumbs the history of sex and Puritan sex attitudes to find that sexual norms were formed and enforced by the colonial founders. In addition to denouncing illicit sexual activity as unclean, Puritan church officials were intent on reversing the social acceptance of premarital sex that was so common in England. As Godbeer has asserted, "Early Americans worried about sex because they believed that it embodied, literally, their identity and worth, individually and collectively" (9-11). This helps to explain, in part, the campaign by Puritan leaders against illicit sex and why sexual acts became crimes in New England. While bodily fluids represented one aspect of uncleanness, sexual acts represented another. Fear of contamination by uncleanness warranted strict regulation of sexual activity as an important part of Puritan New England, and sexual order became an indication of the overall order in the colony (Ingebretsen 23). Statistically, the number of women versus men accused of crimes in Massachusetts in the late seventeenth-century escalated when the crime was categorized as unclean or as a pollution, a description most often used in association with sexual crime, equating to the capital crimes of adultery, fornication, witchcraft, and concealment 
of a bastard corpse as the crimes with the most female defendants (Hull 44). Carol Karlsen, in The Devil in the Shape of a Woman: Witchcraft in Colonial New England (1998), notes that the numbers of men and women who were accused and punished for crime were more equivalent in the period 1640-1644 in Massachusetts, but that ratio began to change drastically as the century progressed. Karlsen argues that this change is brought about in part by the way that certain crimes began to be linked specifically to female sexuality. ${ }^{59}$ Karlsen gives the example of Roger Williams' letter to John Winthrop, Jr. condemning adultery as "that filthy devil of whorish practices" (qtd. in Karlsen 196). Karlsen claims, "Williams' words suggest that the idea that women led men to sexual sin was too deeply embedded to be eradicated easily" (196). While other scholars have argued that women make easy targets for Puritans, the narrative of women's connection to corruption is much lengthier. When female sexuality is implied or explicit in the crime, a woman's connection to corruption works against her, particularly against those women convicted of crimes such as witchcraft and concealment that are already gendered. When the crime itself is less gendered, there is less likelihood that a woman would be singled out. ${ }^{60}$ More specifically, Hull argues that "most Puritan thinkers were utterly opposed to the display of female sexuality" and their approach to handling such displays equated to "an obsession with the danger of female sexuality" (Hull 11). Unregulated sex was inherently female, claims Ingebretsen, and signaled communal decline (23). The excessive number of sexual cases brought to court reveals just how

\footnotetext{
${ }^{59}$ Ingebretsen also suggests that specifically "unregulated sex" was female and that "unregulated" was a direct threat to the community, 23.

${ }^{60}$ Hull suggests that for less gendered crimes the number of men and women brought to trial are closer in number. But, when the crime is gendered, Hull cites the crime of witchcraft, the overwhelming number of defendants are women. More than 90 percent of the defendants in witchcraft trials in England were women. Hull, 26-27.
} 
zealously officials carried out their responsibility (Godbeer 102). The fact that crimes of witchcraft and concealment, both sexual crimes, resulted in the highest number of female defendants is proof of the zealots' success.

Though men were just as likely to receive the same types of punishments as women for the same crimes, women were far more likely to be cast as deviant, and women's deviance was seen as a larger sign of God's displeasure. "Females, already under special scrutiny for their potential corruptiveness, committed the same crimes as men with very different effect upon their neighbors and their rulers" (Hull 12). A historical look at religiosity suggests the origin of these ideas. In Damned Women: Sinners and Witches in Puritan New England (1997), Elizabeth Reis argues that during the witch trials, women were judged and condemned based on "religiously founded notions of their nature and proper sphere" and women were believed to have sinful natures while men had natural sins (11-12), suggesting that men's behavior is related to a propensity to sin and be forgiven while women's sins goes deeper than just the act. John D'Emilio and Estelle Freedman, in Intimate Matters: A History of Sexuality in America (1997), suggest that the polemics against sin reveal a gendered narrative in colonial New England. While men were more often associated with public disturbances - violence or drunkenness - women "bore the brunt of private transgressions" (5). Lyle Koehler, in $A$ Search for Power: The “Weaker Sex” in Seventeenth-Century New England (1980), discusses how women faced even greater pressure than men to suppress sexual desire because "if a woman happened to engage in uncleanness, it would leave an indelible imprint upon her character . . she could, with one act of intercourse, be transformed from an admirable virgin to a despicable whore or slut." Koehler contrasts the position of 
women with men by pointing out that the woman is corrupted and ruined while the man simply committed folly (74). ${ }^{61}$ Though the punishments for sexual crimes would have been proportionate, the rhetorical structure of the jeremiad, and the subsequent call for self-reflection, would likely be altered given the Puritan community's disparate way of evaluating a woman's sin versus a man's.

\section{Kelly A Ryan, in Regulating Passion: Sexuality and Patriarchal Rule in}

Massachusetts, 1700-1830 (2014), claims that part of the inflamed attitudes about women's sexual behavior resulted from a growing concern over marriage in Puritan New England. Marriage, Ryan argues, was central to maintaining gender and power structures within marriage (16-17). Cautionary tales of sexual fornication were meant to preserve pubic order and maintain "religious foundations of society through the institution of marriage" (Ryan 17). Ryan claims that marriage was a metaphor for understanding the relationship between parishioners and God and between the government and the people because a marriage resembled their sacred covenant (17). "Sexual intercourse before marriage defiled the covenant because it suggested couples sought marriage to fulfill their sexual desires rather than to create a union between themselves and God" (17). A change in what Ryan calls gender culpability occurred between the years 1692 and 1725, and by the 1740s nonmarital sex accounted for the largest number of fornication prosecution: between 63 and 97 percent (23). ${ }^{62}$ While infanticide was on the decline, women's sexual culpability was on the rise. By the 1750 s, prosecutions of women for fornication rose to between 90 and 100 percent of nonmarital fornication prosecutions. Ryan argues that fornication became a completely gendered crime, with the last prosecution of a man

${ }^{61}$ Ingebretsen also find that women were burdened with the blame of "private" transgressions, 25.

${ }^{62}$ These numbers represent Worcester, Middlesex, Plymouth, and Suffolk counties of Massachusetts. 
coming in 1758. Men could be held responsible for the care and maintenance of an illegitimate offspring but women were still subjected to public prosecutions with a public whipping or a fine in addition to the maintenance of the child (Ryan 24). Whether a woman married because of an illicitly conceived pregnancy or not, she was likely to receive the same punishment by the court (Ryan 25). Women's sexual behavior remained the primary concern for Massachusetts. Adultery and fornication have obvious connections to female sexuality. But witchcraft and concealment have connections that, at first glance, are less obvious. Witchcraft, Karlsen argues, was born from a period of rising accusations of sexual misconduct in Massachusetts. Between 1636 and 1650, Essex County court presided over only fifty-six cases of sexual misconduct. During the decade of 1670, the same court heard 237 cases against sexual offenders (Karlsen 198). While sexuality was not the singular threat in witchcraft accusations, sexuality did play a large part of the concern. Karlsen points out that part of the narrative against a witch was that she invaded men's bedrooms at night: "Implicit in these tales of witches' night wanderings is not just that they forced themselves sexually on unwilling men but that witches' carnal appetites were both internally uncontrolled and externally uncontrollable" (Karlsen 137). Female sexuality was a danger because it presented a threat that could not be controlled. Hull argues that the hysteria surrounding witchcraft was less about a true threat of the devil and more about religious anxiety and the perpetuation of the Puritan faith (Hull 14). The elevation of adultery and bestiality to the category of capital crimes reflect another connection between sexual crimes and the threat to the colony. Karlsen notes that "For the period 1650-1700, charges of sexual misconduct in Essex County show a new focus on illicit conceptions and, especially, illegitimate births, 
rather than on sexual misconduct per se. This new concern made women, as the bearers of children, more vulnerable to public scrutiny" (198). While men are as guilty of illicit sexual behaviors, it is nearly impossible to hold them responsible without proof of their involvement. A woman, in contrast, bears the proof of the illicit sexual transgressions when she produces an illegitimate child. It is the illegitimacy that acts as proof of illicit sex. "By the 1680 s at least 60 percent of prosecutions were against women" (198) and that percentage continues through 1700. Specifically, Karlsen notes that between 1671 and 1690, 214 women were charged with sexual offenses in Essex County. (Table C: Prosecutions for Sexual Offenses, Essex County, Massachusetts, 1636-1700, Karlsen 337). In Daughters of Eve: Pregnant Brides and Unwed Mothers in Seventeenth-Century Massachusetts (2004), Else Hambleton calculated the same archival material in Essex, and found that in those same years 177 women were convicted of either illegitimate or premarital fornication (45). ${ }^{63}$ These numbers show that the majority of convicted women were judged guilty of sexual crimes resulted because of a pregnancy. We can argue that the crime was sexual but also question whether the crime was the concealing of a sexual liaison and that the proof, the pregnancy, was the evidence.

While concealment seems less likely to be seen as unclean, it is, like the other capital crimes here, a crime that was promoted as illicitly sexual in the discourse of the period and connected to female sexuality in particular. This chapter explores the language of both the unclean and of concealment in sermons delivered in response to a woman's conviction under the 1624 statute for concealment. More specifically, I connect Karlsen's

\footnotetext{
${ }^{63}$ Karlsen's research does not break down the sexual crime data into pregnancy and Hambleton does not discuss crimes other than illegitimacy and premarital pregnancies. Therefore, I correlate the numbers from their data and limit it to the years of 1671-1690 to keep the ratio correct without skewing the results.
} 
claim that the language of sexual crimes was attached to images of female sexuality with Hull's argument that bastardy in Elizabethan England was a monetary burden as a starting point to discuss how the attitudes of lawmakers, judges, and ministers of Puritan Massachusetts reflect more about the concealment statute than the language of the statute itself reveals. I argue that the language used for the act of concealing in crimes of concealment reflects assumptions about the criminal that are condemning both female sexuality and the act of concealing.

Chapter one of this dissertation showed how the 1624 statute for concealment was an odd inclusion to the Massachusetts Bay laws because the other laws were incorporated with a biblical counterpart to justify their inclusion while concealment was not. And yet, the statute was included in the reform laws of 1696. Hull argues that "The framing of criminal law is a social process and so reflects the fears and desires of community leaders, some of which are widely shared in the community, others of which reflect a struggle to maintain power and control behavior" and that some criminal law ${ }^{64}$ functions regulate conduct of "dangerous classes" (Female Felons 20). The enforcement of the concealment statute targets women specifically and the language of the statute enables the magistrate and the court to convict them through the embedded language of sexuality, secrecy, and doubt.

An act to prevent the destroying and murthering of bastard children.

WHEREAS, many lewd women that have been delivered of bastard children, to avoid shame, and to escape punishment, do secretly bury or conceal the death of their children, and after, if the child be found dead, the said woman do alledge,

\footnotetext{
${ }^{64}$ Hull terms these as mala prohibita, crimes that are considered evil at a particular time and place, versus mala in se, crimes that are considered to be evil in themselves (Female Felons 19).
} 
that the said child was born dead; whereas it falleth out sometimes (although hardly it to be proved) that the said child or children were murthered by the said women, their lewd mothers, or by their assent or procurement:

II. For the preventing therefore of this great mischief, be it enacted by the authority of this present parliament, That if any woman after one month next ensuing the end of this session of parliament be delivered of any issue of her body, male or female, which being born alive, should by the laws of either by herself or the procuring of others, so to conceal the death thereof, as that it may not come to light, whether it were born alive or not, but be concealed: in every such case the said mother so offending shall suffer death as in case of murther, except such mother can make proof but one witness at the least, that the child (whose death was by her was so intended to be concealed) was born dead. (qtd. in Hoffer and Hull 20).

The statute clearly defines the crime of concealment and does so by choosing language that condemns secrecy and efforts made by the woman to conceal the death. Yet, also inherent in the language of the statute is sexuality. Her sexual behavior is identified by the term lewd and her shame is identified by assuming her motive is to avoid the shame of discovery. Additionally, by suggesting she was avoiding punishment, she is labeled a trickster and a liar by alleging the possibility of a stillbirth. The subtext of the statute, "although hardly to be proved," immediately instills doubt about a woman's claim. The second part of the statute labels the act of concealment a "great mischief" and creates an association with a female trickster. Given that the parable of Adam and Eve was a foundation for the education of young people, the association with a trickster woman is 
not lost on a Puritan community. While it can be argued that the language of concealment was the very essence of defining the crime, there is evidence to suggest that the act of concealing was something more to the Puritan community, especially when it came to the law.

Peter Charles Hoffer, in "Principled Discretion: Concealment, Conscience, and Chancellors" discusses the use of chancellors' discretion in judicial proceedings involving concealment of material conditions of goods exchanged in sale. Hoffer argues that their discretion was based on conscience informed by moral knowledge. "The means that they used, therefore, were rooted not in law...or in equity itself...but in their appreciation of shared dicta in moral philosophy...to gauge the moral intentions of the parties... and that it is right and fitting to impose contemporary moral standards upon the transaction" (Hoffer, "Principled Discretion" 54). The revelations revealed in treatises, written by prominent judges of the antebellum period from New York and Massachusetts, proclaim "the capacity of chancellors to penetrate the veneer of legal claims ... to reorder the world" says Hoffer: "The real stakes had less to do with sales contracts per se than the fate of courts of equity and the discretion of chancellors" (Hoffer, "Principled Discretion" 60). If these revelations can be found in the musings and declarations of principle judiciaries in the mid-1700s, there is likely evidence to suggest that gauging the moral intentions of those who came before the criminal courts of Massachusetts Bay, a colony with a commitment to reform the moral laxity they endured in England, was also typical of the magistrates of the mid-1600s as well, particularly against colonists brought before the courts for morally reprehensible crimes. For example, if concealment was understood as morally reprehensible, what would the attitude be towards those whose crime was 
concealment? We can infer from the judges' attitudes over concealment of the condition of material goods by plaintiffs that the crime of concealment, because of the inherent secrecy in its construction and its execution, would also be seen as reprehensible because female sexual behavior was constructed as secret and hidden as early as 1637. A broadside condemns the "sensual Joys and low Delights, That Women give...all the nights" and names the "hidden things" and "the darkest things" among them (Ingebretsen 27). Therefore, unacknowledged illicit sexual behavior, a hidden pregnancy, a concealed murder, and secret burial committed by a woman were understood by her contemporaries as both lewd and corrupt and would have drawn serious condemnation from the judge as concealing.

Hoffer quotes a prominent moral philosopher, William Paley, to discuss the unfair advantage the seller has over the buyer for concealing important details, "the faults of many things are of a nature not to be known by any, but by the persons who have used them; so that the buyer has no security from imposition, but in the ingenuousness and integrity by the seller" (qtd. in "Principled Discretion" 78). A woman on trial for concealment was essentially the seller of her own story for the occurrence. In a contract between the woman and the community, she has defaulted on her part of the contract by concealing the death of the child and likely concealing her entire pregnancy and by extension her sexual knowledge because her unwed status also makes her guilty of sin. "If one conceals a defect to make such an examination by another impossible, one is blameworthy" (Hoffer, "Principled Discretion" 78). The very nature of concealment is blameworthy. Therefore, for the crime of concealment, no real prosecution was needed to convict a woman for concealment of the death of an infant, only the statute itself. Indeed, 
not even evidence, other than the corpse of a child, was needed to convict her. For Hoffer's inquiry he finds "People were not inherently sinful, they had innate senses of decency and honor, and when they violated these humane traits, their actions betrayed them to the senses of the chancellor... one may say that the moral philosophy saw the relationship between perceiving the good and acting in moral fashion in the same way that the conscience of the court saw the relationship between evidence and culpability" ("Principled Discretion" 79-80). These thoughts are more in line with the pending enlightenment thinkers: for sixteenth-century Massachusetts Bay, sin was inherent. And, the culpability of the woman accused for concealment came from the language in the statute itself: "many lewd women that have been delivered of bastard children, to avoid shame, and to escape punishment, do secretly bury or conceal the death of their children" (qtd. in Hoffer and Hull 20).

Not only unearthing a crime but also a sin, concealment plays another part in the colonial discourse. Thomas Nagel, in "Concealment and Exposure," examines the philosophical nature of privacy in a community: "The essential function of the boundary between what is acknowledged and what is not is to admit or decline to admit potentially significant material into the category of what must be taken into consideration and responded to collectively by all parties" (12). The crime of concealment is then a doubleedged sword for the Puritan community: once discovered, it forces a woman's secrecy into the category of crime but also forces a woman's sexuality into the center of public discourse. While it would seem that a community possessed of an aversion to women's sexuality would avoid it altogether, making concealment a crime that provided ministers an opportunity to police women's sexual behavior by sermonizing about the danger her 
sexuality posed to the body politic. "What is allowed to become public and what is kept private in any given transaction will depend on what needs to be taken into collective consideration" (Nagel 13). By making concealment a crime, ministers were able to publicize the private sexuality of women but also to "make explicit acknowledgement function as a signal that something must be collectively dealt with or faced" (Nagel 16). Bringing her sexuality and her secrecy to the forefront of the sermons allowed ministers to treat women's sexual behavior as a threat to the community. "The attempt to control public space is importantly an attempt to control the cultural and ideological environment in which young people are formed" (Nagel 24). The rise in suspicions and convictions, the use of the jeremiad to sermonize at the gallows, and the publication of a woman's “dying words" all point to the minister's attempt to use concealment as a way to both control women's sexual behavior and to use her conviction to locate sin in her convicted body.

Of the 71 cases of infanticide prosecuted in Massachusetts between 1670-1780, Hoffer and Hull suggest that 51 of those would have also been punishable under the 1624 statute's guidelines, with the greatest number of cases and convictions developing in 1690 (39-41). As explained previously, this means that 51 cases brought to court involved a bastard child, a woman previously censured for her conduct, and the concealed body of an infant. And, there was a greater chance of being convicted for infanticide from 1630 to 1692 than being convicted for the murder of an adult (44-45).

Even more revealing than the numbers of convictions is the amount of crime literature published. As discussed in chapter two of this dissertation, literacy was intimately tied to becoming religious and sermons printed in the colonies acted as God's 
Word, making them as sacred as the Bible itself. "What was printed was to be received as though it had been spoken, and therefore as the truth" (Hall, Worlds of Wonder 38-39). As these jeremiad sermons moved from the meetinghouse to the center of town, and because the growing number of people in the gallows crowd was extremely large, some execution sermons were published beforehand. At the very least, execution narratives and "dying speeches" were produced by ministers in collaboration with the criminals in time to be published and distributed to the gallows crowd. Because the decision to print was based on perceived demand, and in order to get them in the hands of the crowd by hanging day, printing execution discourses was a priority (Hall, Worlds of Wonder 4849). My research investigates, first, the language of these sermons for evidence of both uncleanness and secrecy to understand how the community's aversion to these are linked together in the crime of infanticide, known and prosecuted in Puritan Massachusetts as concealment. By focusing on sermons that are accompanied by narratives, or dying words, I also examine this unique form of crime literature for evidence of how these women, with the extensive help of the minister, acknowledge their corruption in order to secure the cleanliness of the community and alleviate God's wrath as the fulfillment of the jeremiad.

Even though colonial women had been convicted prior to the implementation of the 1624 concealment statute, not one gallows sermon for an infanticide case was published prior to its incorporation into colonial law in 1696. The first infanticide execution sermon published in New England was Cotton Mather's Warnings from the Dead (1693). Though it was published for her execution in 1693, Elizabeth Emerson was convicted two years prior, in 1691. Kathleen Brown, in "Murderous Uncleanness: The 
Body of the Female Infanticide in Puritan New England" (2001), examines Emerson's case and discovers overwhelming proof of the language of sexual sin and focuses on Mather's efforts to link providential and medical views of the body. Brown also suggests that infanticide becomes a way for ministers to recover from the witchcraft debacle and to reestablish their credibility within the community. Given that Emerson's case is the first infanticide conviction to be published in New England, and Brown's claim that the 1690s were the harshest decade for infanticide crimes, her argument is well supported (78). While infanticide convictions may have been higher in the last decade of the seventeenth century the number of sermons, and the addition of narratives and "dying words," published in New England suggests infanticide served a greater purpose in Puritan New England than the reestablishment of the ministers' credibility. Just as Brown examines Mather's sermon, Warnings from the Dead, I examine Thomas Foxcroft's sermon, Lessons of Caution to Young Sinners, published on the occasion of Rebekah Chamblit's execution for infanticide in 1733. Over four decades after Emerson, and well-past the decade noted for the highest number of convictions for infanticide, Rebekah stands on the gallows, subjected to a similar scathing attack. Just as Brown's scholarship examines Mather's sermon, my research investigates Foxcroft's choice of scripture, his references to the body, and his references to secrets, hiding, and sin in addition to the unclean.

The Sunday before Rebekah Chamblit was executed, September 23, 1733, Foxcroft delivered his sermon in the meetinghouse. Three days later, Rebekah's Declaration, Dying Warning and Advice was "carefully taken from her own mouth" in order to be "published to the World, and read at the place of execution." Ministers used the execution scene to "evoke a sense of urgency particular to their time and place" 
(Williams 7) making the declaration a key device for assuring this. Thus, on September 27, Rebekah walked to the gallows, stood on the weathered boards facing the community she had grown up in, stared into the faces of people she recognized and who recognized her, and listened as Mather Byles read aloud. Days later, the sermon, along with a preface written by W. Cooper and followed by Rebekah's Declaration, was published. Rebekah's case appears to be the only instance where such materials are grouped together and accessible.

Rebekah's experience provides a unique opportunity to examine how these three synergetic texts contribute to a larger argument being made by those who produced them. We can't be sure the sermon was read at the gallows, though previously this was the case with other infanticide crimes. Regardless, the community would have heard the sermon on Sunday and the potent metaphors and carefully chosen scriptures of Foxcroft's jeremiad would be evoked by the sight of Rebekah on the gallows. In addition, Rebekah's declaration was at least read at her execution, if not published before her hanging. ${ }^{65}$ The immediacy and potency of these texts characterized the message received by the gallows crowd witnessing the execution. The message and the visual image of the female infanticide helped shape and perpetuate the prevailing attitudes about women's sexuality. By examining the intervals at which these rhetorical devices played their part in the gallows drama of Rebekah Chamblit we can better understand how they are mutually reinforcing the Puritan ministers' message. Addressing Rebekah's sexual sin rather than

\footnotetext{
${ }^{65}$ The sermons would often follow later and be printed along with the supplementary narratives, reprinted in pamphlet form within a week or two, and offered for free or for a very minimal cost: making them widely available, and popular, to even the lowest of wage earners. The pamphlets were then distributed throughout the colony through booksellers or sold at the press offices themselves (Cohen 4).
} 
her crime is an effort to lay both guilt and blame for sexual uncleanness on her postpartum body in order to create cohesion amongst a community torn by God's wrath.

Foxcroft's sermon was similar to other jeremiad sermons delivered before infanticide executions. Rebekah's execution provided the platform for Foxcroft's message and he chose to address the familiar message of the unclean, a term encompassing all elements of sexual wrongdoing (Cohen 47), including Benjamin Goad's case of bestiality in a sermon delivered by Samuel Danforth. The basic parts of the jeremiad are met in Foxcroft's sermon: the doctrine, those whose lives are unclean are taken out of this world by an early death; the reasons, there is uncleanness in this community; the application, the community should be on the lookout and reprimand those whose lives are unclean. For Foxcroft, the selection of Job 36:14, "They die in youth, and their life is among the unclean" provides the framework for his sermon, along with his reliance on the public's familiarity with the term unclean.

Brown discusses Cotton Mather's use of the term unclean in his sermon delivered at the execution of Elizabeth Emerson. Contemporary Puritan attitudes of uncleanness and filth-avoidance practices produced the most potent rhetoric used to define moral cleanliness. Mather evokes the metaphor of filth and self-pollution in association with the unclean, thus solidifying Brown's argument that the female infanticide is an object of uncleanness. "Executions of female criminals," she notes, "allowed ministers to minimize the abstraction in the metaphor of the unclean body and to explain graphically the danger sinners posed to the Puritan social body" (Brown 82). Here the use of the unclean is most obviously the insinuation that this body can pollute the body of the colony. 
Alan D. Hodder, in “In the Glasse of God's Word: Hooker's Pulpit Rhetoric and the Theater of Conversion" (1993), argues that despite the Puritan minister's condemnation of theater in the Shakespearean sense the ritual of rhetoric in sermons "is but one step to drama" (86) and the "pulpit rhetoric strives to dissolve the fictive...he has brought all his rhetorical forces to bear on persuading his audience that their imaginative identification is actually real" (89). At the gallows, while the minister is aiming for the dramatic effect, his sermon language forces the mind to understand the drama as real. The minister's use of language calls listeners to consider or conceive or imagine is a call to visualize what is being said (Hodder 88). Such as Brown suggests, the body on stage is the potential pollutant. Jodi Schorb uses the case of Esther Rodgers to argue that "infanticide sexualizes the body of the woman on the gallows, most obviously because the crime marks the woman's body (mostly young, mostly unmarried) as a site of sexual knowledge" (73). The crime of sexual sin is the threatening pollutant. Foxcroft expounds on the cataclysmic sentence awaiting these scarlet whores and mothers of harlots by choosing Revelations 18:5-7, a passage referring to Babylon's destruction but useful to Foxcroft as he continues to focus on the gendering of sexual sin by selecting scripture using the female pronoun:

Her sins have reached into heaven, and God hath remembered her iniquities. Reward her even as she rewarded you, and double unto her double, according to her works: in the cup which she hath filled, fill her to her double. How much she hath glorified herself, and lived deliciously, so much torment and sorrow give her. Though this section of the jeremiad is supposed to address the community as a whole in order to inspire retrospection Foxcroft chooses scripture that identifies with a woman. 
Though the masculine pronoun was typically used to refer to the community, here Foxcroft chooses a passage that uses the feminine. His choice of scripture destabilizes the universality of the jeremiad, creating a language that targets women specifically and changes the intended self-reflection by the gallows crowd into condemnation for Rebekah.

Similarly, the language used by Foxcroft identifies the body of the female infanticide as the source of the unclean, but he also creates additional metaphors to draw attention to Rebekah's sexual sin, and her postpartum body, as well as her crime. Given that Rebekah was convicted under the terms of the 1624/1696 statute, and the statute's language is "she endeavor privately, either by drowning or secret...to conceal the death thereof, that it may not come to light....but be concealed," the use of this same language in the sermon denoting the secreting of sin reveals Foxcroft's creation of a metaphor, a tool employed by Puritan ministers to illuminate the meaning of their message, to draw attention to both Rebekah's crime of concealment but also to her postpartum body. Foxcroft states that "their life is seen to have been among the unclean" but "may have hid their wickedness." For Rebekah, and other female infanticides, it is only the birth of a bastard child that provides the proof to condemn her for sexual sin. Foxcroft goes on to say "the providence of God strangely brings to light their hidden iniquities," thus crediting God with the revealing of sin but also the scriptural connection to Rebekah's childbirth, and her postpartum body. The use of the word "light" carries a heavy connotation of hidden sin but also a historical and cultural connection to both the womb and childbirth. 
Childbirth metaphors of light and darkness can be traced back to the ancient world. Zeus announces in book nineteen of Homer's Illiad, that the goddess of childbirth, Eileithyia, "will bring into the light a man who will be lord of all who dwell around him" (lines 103-104), referring to the pending birth of Herakles. The use of "into the light" as a metaphor for childbirth is used again in line 118, "Hera brought her son into the light two months premature" (Sachs 312). While Eileithyia was the Greek goddess controlling childbirth, her Roman counterpart was Lucina, goddess that "brings to light" (Smith 825). This Roman meaning could be the source of the Italian phrase dare alla luce, which refers to giving birth, but is literally translated as "to give to the light" (Deeb). The metaphor for "bring to the light" can also suggest the darkness of the womb. The connection between darkness of hidden things, such as a child hidden in the womb, also reflects the hiding and secrecy that was part of the childbirth experience in Puritan New England.

Laurel Thatcher Ulrich, in Good Wives: Images and Reality in the Lives of Women in Northern New England, 1650-1750 (1991), notes that details of the childbirth experience are virtually absent from many historical texts because childbirth was exclusively attended to by women (127). In fact, Ulrich argues that husbands, by nature of their sex, were removed from any participation. "Not only the birth itself but the husband's very awareness of the progress of the birth was controlled by the women" (131). Ulrich even goes as far as to suggest that while the travails of childbirth were connected to the sins of Eve, "it might also become an instrument of female power" (145). Though Anne Hutchinson's home meetings were not held in secret, a conclave of women attendants as a scene of female power would have been familiar to the Puritan 
community. The gender dynamics of the cultural childbirth experience in Puritan New England, combined with the historical perspective of childbirth metaphors contribute to the way the use of "light" in Foxcroft's sermon functions to identify Rebekah's postpartum body.

Foxcroft uses scripture that is oddly chosen to make his point but proves useful in drawing attention to the fact that this crime was committed by a woman and that the criminal is the body of a postpartum female infanticide. Foxcroft employs these references and metaphors in the portion of the jeremiad Perry Miller calls "the reasons" or "God's justification for wrath" ("From Colony" 28-29). While justifying the punishment of sin for anyone who sins with the knowledge that they commit a sin, Foxcroft constructs his argument as "The sentence passed on the scarlet whore, the mother of harlots, will be the language of the great day, in regard to some sinners." Though "some sinners" is mentioned at the end of the passage, Foxcroft identifies two figures distinctly emblematic of the female infanticide: whore and mother. A definitive connection wasn't need by listeners, and eventual readers of the sermon, to understand Rebekah as the whore and mother because Puritans were familiar with the use of symbolic language. David D. Hall discusses the permanency of symbolic language by saying, "The archetypal source was Scripture. Its figures, tropes, and stories were echoed and reechoed in almost every kind of text that people came in contact with ... It even overrode the gap that may have separated readers and nonreaders, because it lent itself to visual presentation" (Hall 69). This visual presentation was the postpartum body of the unclean Rebekah Chamblit, but it is also Foxcroft's language of concealment the gallows crowd is asked to visualize. 
Foxcroft may be guilty of what Neuman describes as "the tendency to explore a verse, if necessary, one word at a time," or what has been termed "text crumbling." (144). "Text crumbling is a literary and rhetorical preference rather than a denominational marker, however, and a charge of text crumbling would necessarily be in the eyes (or ears) of the beholder. For a committed practitioner (as for his auditory or reading audiences) the deep resonance of even a single word of scripture could not always be bound to a single, simple meaning" (144). From our contemporary perspective, one word or one verse may seem part of a larger objective within a sermon, but Foxcroft's language of concealment is part of a sermon culture unique to the Puritans. "When a minister exhorts his congregation to 'imagine' the bloodied head of Christ, to 'conceive' him knocking at our door, he does so in the service of two motives: first, to dramatize the biblical text, thus highlighting its reality; and second, to spur each member ... to begin transferring the locus of personal identity from the individual (themselves) ... to the Soul on stage, in public view, undergoing its torturous ordeals" (Hodder 88-89). Essentially, the language of concealment asks the crowd to focus on concealing; they transfer the danger posed to the colony to Rebekah. Even more than that, the lived-experience of the gallows crowd in sight of the physical post-partum body of Rebekah not only marks her as unclean but also highlights the threat of concealing sin. The details of her crime enumerated that she concealed her pregnancy, the statute enables the court to find her guilty of concealing the body of her infant, and Foxcroft's use of biblical and symbolic language point to her post-partum body as evidence of her ability to conceal things from her community and from God. 
Continuing with his lecturing of sin and punishment, Foxcroft references childbirth as he warns against how swiftly one can be found out and punished, "lest sudden destruction come upon you, as travail upon a woman with child" (13). This inclusion of childbirth as an example of swift onset of punishment is not only an odd reference for a jeremiad, but the passage is based in scripture directly related to the pains of childbirth God puts on a woman as a result of Adam and Eve's sin found in Genesis 3:16. Foxcroft's positing of God's punishment for Eve's sin brings together sin and childbirth, and brings forth the images of the unclean that provides the basis for the sermon. Foxcroft finds the scripture and provides the connection for his listeners. Puritan aversion to filth was intimately linked to women in the case of childbirth. Linens, procured and passed down from mother to daughter, exclusively used during delivery were carefully cleaned and hidden away from everyday use because of the material connection to the bodily filth of blood and semen (Brown 87). "For many preachers of the period, a full contemplation of the single word is necessary to tease out the essence of its divine logic in the verse ..." (Neuman 143). Rather than explaining Foxcroft's selection of childbirth as an analogy of the swift onset of pain, his selection is better explained as a deliberate reference to Eve's sin as a means of drawing attention to Rebekah's postpartum body and the association of childbirth and the sexual unclean and the bodily unclean.

Brown argues that by the 1720 's ministers and courts were embracing a new view of motherhood, emphasizing innate piety and maternal tenderness (91). Whether that is a true assumption or not, Foxcroft uses motherhood as additional ammunition against Rebekah. The language of motherhood also plays a part in what is referred to as the 
"application" portion of the jeremiad where Foxcroft instructs the community on how to avert future wrath. He continues with the references to motherhood and childbirth neatly connecting the message to Rebekah's body on the gallows: "God has put into parents a natural affection to the fruit of their own body; so that they are tenderly concerned for the welfare of their children ... can a mother forget to have compassion on the son of her womb!" (18-19) His reflections are on the surface meant to plea to parents to save their children from uncleanness, but the gallows crowd is also imminently aware that Rebekah is believed to have killed her own child, thus becoming something unnatural and unconcerned for the son of her own womb. Rebekah has denied her own motherhood.

The message is meant to increase a self-reflection, yet the result of Foxcroft's message is combined with the image of Rebekah on the gallows to assign guilt and blame and her execution now functions as the purging of sin from society. The jeremiad, in its original form and use within New England, was to explain why disastrous events were occurring and call for repentance by the community. Instead, Foxcroft's jeremiad, like others delivered at infanticide convictions, focused on the body in order to address sexual sins, creating a rhetorical device for assigning the guilt to women rather than the community as a whole. This sin described by Foxcroft can only be purged by those he has identified as guilty through carefully chosen language and scripture: women with the power to conceal.

Puritan attitudes about female sexuality help cement the easy assumption of guilt against women suspected of concealment. This converted use of the jeremiad targeting Rebekah's body meshes well with the established archetype for sexual sin. Aided by Foxcroft's use of metaphor and carefully selected scripture, the body of the convicted 
became a useful tool because of the sexual nature and the secrecy of her crime.

Rebekah's postpartum body and the corpse of her infant provide the proof so earnestly needed by this Puritan community emerging from the uncertainty of witchcraft and the uncertainty of their own election to sainthood.

Contrary to our contemporary understanding of crime, sin and crime were one and the same for Puritans: "The theological understanding of crime [resulted] from God's just abandonment of the sinner to his own corrupt impulses" (Cohen 84). This ideological framework gives way to two enthymemes ministers and the community used against women: women were more closely associated with sin than men and women were more likely to be guilty of crime. This phenomenon, combined with the incorporation of the 1624/1696 statute, creates an increased atmosphere of guilt associated with women, a guilt that they remove from the community and take to their graves. If the Puritan jeremiad, in its newest form ${ }^{66}$, typically calls for the purging of sin from the community and the woman on the gallows is a representation of this sin, then the community is relieved of its culpability. In Rebekah's case, her declaration, a form of confession so important to Puritan cosmology, relieves the community of its culpability, and her death removes the symbolic threat of corruption, reinforcing the female embodiment of sin and the unclean and secrecy. A process of disavowal from the community that begins with the sermon targeting her secrecy and her body as a site of sexual knowledge is sealed with her "dying words" and a drama played out at the gallows.

\footnotetext{
${ }^{66}$ Chapter two discusses the change that Miller sees in the rhetorical structure of the jeremiad.
} 
CHAPTER FOUR

FOUL TRANSGRESSOR OF THE WOMB:

THE DISAVOWAL OF THE INFANTICIDAL BODY

AND CONCEALER OF SIN

"Who can find a virtuous woman? For her price is far above rubies.

The heart of her husband doth safely trust in her,

So that he shall have no need of spoil.

She will do him good and not evil all the days of her life."

Proverbs 31:10-12

Many historians cite evidence that Puritans were concerned with pollutions,

particularly illicit sexual behavior, as potential threats to their colony. Yet, as shown in

the last chapter, concealment, both the crime and the act of concealing, was also

considered reprehensible. Thomas Foxcroft's execution jeremiad used a common

vernacular laden with metaphors and analogies to express the threat Rebekah Chamblit

posed to the colony. The symbolic language and biblical scripture Foxcroft used would have been very familiar to the gallows crowd in Puritan Massachusetts. As noted in chapter two, Seay points out that the "doctrine of original sin provided the Puritan execution preachers with the rhetorical means to fashion a moral identification between the condemned criminal and the audiences on hanging day" (48). An examination of Foxcroft's sermon Lessons of Caution to Young Sinners in chapter three revealed his use of the language of secrecy and hiding specifically to address Rebekah's sin. This chapter will examine her Declaration, Dying Warning and Advice to argue that the language used 
in the sermon and the narrative functions to eliminate the metaphor that normally creates a moral identification between the gallows crowd and the convicted. The symbolic language within the decentered jeremiad and the declaration functions instead to target Rebekah's body as the threat to the colony. Her postpartum body represents a woman's ability to conceal evidence of her sexual sin but also represents her denial of her calling to motherhood, a tenant of a virtuous woman in Puritan Massachusetts resulting in her disavowal by the community.

For Puritan ministers, control lay with the ability to deliver a powerful message to the largest number of people in their community. Clergymen delivered their sermons from the pulpit either on the Sunday before an execution or on the day of the hanging, typically drawing between 550 and 850 people to hear the actual sermon (Minnick 79). Because the church could only hold a certain number of members, the execution itself drew an even larger crowd. As the minister and the condemned left the church for the scaffold, more spectators would join them and the number of people grew to the thousands (Williams, "Behold A Tragic Scene" 831; Minnick 79-80). Because the growing number of people in the gallows crowd was significantly larger than the sermon crowd, it was a chance not to be missed by opportunistic ministers. Some execution sermons were published beforehand, but at the very least execution narratives and "dying speeches" were produced by ministers in collaboration with the criminals in time to be published and distributed to the gallows crowd. Because the decision to print was based on perceived demand (Hall, Worlds of Wonder 48-49), and in order to get them in the hands of the crowd by hanging day, printing execution discourses was a priority (Cohen 
4). ${ }^{67}$ Ministers used the execution scene to "evoke a sense of urgency particular to their time and place (Williams 7) making the declaration a key device in the gallows drama produced for the greatest effect.

David D. Hall claims "Executions in New England followed a strict pattern . . .they involved certain gestures and a set of rules" (Worlds of Wonder 178). Executions required a procession to the scaffold, a scaffold speech, prayers, and a sermon delivered by a minister. The pattern allowed for the criminal to confess or at least repent their current state (Hall, Worlds of Wonder 178-179). Though confession or criminal performances were not always guaranteed, "the meaning of the ceremony remained what the ministers prescribed. They were almost always present, and their testimony about someone's struggle for repentance was the sole source of such information" when not given by the criminal themselves (Hall, Worlds of Wonder 181). The creation of the criminal narrative helped to guarantee that ministers maintained control over the gallows drama. "In so regulating the performance of the ritual, the ministers had allies in the magistrates and printers ... How it happened that printers and the clergy joined forces is not possible to reconstruct" but in the later part of the 1680 s printers were turning out execution sermons with nearly every execution and began printing broadsides with the criminal's dying warnings (Hall, Worlds of Wonder 182). This dissertation has already established that the use of the most powerful form of rhetoric, the jeremiad, was selected to move beyond its use on election days and days of humiliation to sermonize to the

\footnotetext{
${ }^{67}$ My use of execution discourse refers specifically to execution sermons and narratives written in first person account. Though there are other types of discourses and several historians have produced excellent scholarship regarding the genre of criminal discourse, to the point of labeling sub-genres, for the purposes of my research I refer to only the two for specific rhetorical analysis. See Cohen and Hall for more on the genre in general and later classification of the specific sub-genres.
} 
gallows crowd and the jeremiad help assure the ministers of their success in the drama produced by the gallows. Not only was the language of the jeremiad more accessible to the Puritan community than the loftier types of sermons constructed by ministers, the popularity and the effectiveness of the jeremiad was augmented by the scene created at the gallows.

The gallows drama provided an opportunity for ministers, already dealing with issues concerning their validity combined with the increasing non-Puritan population of the colonies, to reaffirm the colony's covenant and solidify their control (Williams, Pillars 11). Ed Ingebretsen argues, in "Wigglesworth, Mather Starr: Witch-Hunts and General Public Wickedness" (2001), that ministers of the time were wielding "an authority that is, in different ways, either discredited or under threat; each wields the transgressive scene in order to define, and stabilize, the community's sense of itself" (28). Since the publication of the execution sermon would have a wider audience than that of the church congregation, the message would have been made as clear as possible. In the sermons, ministers would explain in the reasons how the criminal's wickedness led them to their crime while warning others of doing the same and how their behavior could lead them on the same path, and then justified the punishment of the criminal in the application. The crime itself simply provided the narrative for the sermon, and Ronald Bosco contends that this form is based in Puritan doctrine. Ministers spent equal time and length on an explanation of how the crime was an affront to the national covenant (all wickedness was an affront), how the judgment and punishment matched the crime (biblical justification for capital crimes), how mankind was at risk for more of God's wrath if the community did not take action now and stop further affronts later (that we are 
saved from sin by God) ("Lectures" 164). Thus, execution sermons were an ideal forum for delivering these types of warnings to the community.

As this dissertation has shown, and this chapter continues to investigate, the language of Foxcroft's sermon targets Rebekah's body and his inclusion of metaphors of secrecy, hiding, and seduction deliver ample warning to the community about the threat she poses. The biblical connection to depravity and her conviction for concealment labeled an infanticidal woman as a progressive threat to the community. "In explaining how one sin led to another, the minister employed the powerful imagery of contagion and disease. Wickedness, (the minister) suggested, was a deadly infection that, unchecked, could only spread and destroy its tainted victim" (Cohen 87). But beyond the threat of sin and pollution, what is the threat that Rebekah poses? Foxcroft's sermon title suggests his target audience is young people, but a closer examination finds that his warnings are specifically directed toward young men. Closer examination of his jeremiad shows how Foxcroft is able to make Rebekah Chamblit the subject of his choice of scripture. Ingebretsen argues that in these dramas conducted at the gallows, the ministers were "replacing visibly marked saints with communally repudiated sinners" because the transgressing individuals "were a most direct way of binding the community to itself" (26). While the jeremiad would conventionally place the burden of action on the community to avert further decline, a convicted criminal made for an easy out for both the minister seeking to validate himself by having the backing of the court conviction, and for a community who may or may not buy in to the minister's message. ${ }^{68}$ While the

\footnotetext{
${ }^{68}$ As Brown points out, ministers were recovering from the witch trials. In addition, a huge influx of nonPuritan colonists began to enter New England and it is impossible to know how many were actually in
} 
spectacle encouraged the community to come together, the jeremiad and the narrative enabled the community to also see the necessary expulsion of the threat.

As noted previously in this dissertation, toward the end of the seventeenth-century ministers struggled with the potential for moral decline in their colony. The colony, according to ministers, suffered from an influx of non-Puritans, declining church membership, and an antipathy for vices such as drunkenness, fornication, and Sabbathbreaking. These anxious Puritans were becoming increasingly more anxious and Perry Miller claims the clergy had built up the narrative of a "universal depravity" and by 1679 the "whole body politic was in a bad way" and it was no longer enough to appeal to the Christians of the colony: "In order to effect a national recovery, the whole nation had to be recovered" ("Preparations" 256). As part of this national recovery, the execution ritual, according to Hall, functioned as a "moral allegory of repentance and renewal" (World of Wonder 167); and Scott Seay, in Hanging Between Heaven and Earth: Capital Crime, Execution Preaching, and Theology in Early New England (2009), argues that New England, in comparison to England, limited most death penalty crimes to those that threatened religious and moral purity. ${ }^{69}$ Not only were the occasions for executions enflamed by the crime itself, sermons were composed of some of the strongest language to solidify the minister's call for repentance, and the responsibility of the entire colony's health was in the hands of the gallows crowd.

In addition to the sermon, the drama induced by the gallows scene augmented the effect of the language ministers chose to sermonize about criminals. Because the

attendance and under the influence of the Puritan minister's message. Ronald Bosco discusses the stress ministers were under because of this period of declension (161).

${ }^{69}$ Seay states that England had "no fewer than fifty crimes regularly punished with death" while New England had an original twelve crimes and eight were added by the end of the century (23). 
community labeled, with the guidance of ministers, the felon as a locus of sin, the execution resulted in the aversion of the community's further suffering. Though some sermons used language directed specifically at the criminal, the message contained in the execution sermons was intended for the audience. The sermons delivered at the execution of a criminal possessed particular power because of their relationship to the hanging spectacle. People came to witness the hanging but they were also there to participate (711). "The gallows was a symbol of order, and those who mounted it were there to legitimize the power of those who erected it" (Williams, Pillars of Salt 11).

Ministers spent a large portion of the sermons naming the sins of which the criminal was guilty of and then issuing a direct warning to the crowd adopting the tone of a prophet or even God himself, speaking directly to the audience as Cotton Mather does in his sermon preached at Margaret Gaulacher: "O look inward; enquire within; and, commune with thine own heart" (Mather, "A Sorrowful Spectacle" 8). Mather, at the end of this sermon, addresses the congregation: "And now, Oh! the importunity, the fervency, the EXHORTATION should be charged withal! See to it, O all ye people, everyone of you, see to it" (Mather, "A Sorrowful Spectacle" 73 [emphasize Mather]). Cohen notes, “The clergyman's emphasis on universal human depravity as the wellspring of crime forced readers to recognize their kinship with the offender about to be executed" (84). The concept of "collective guilt" and identifying the threat to all people helps to draw in the entire community: “one person's particular depravity thus served as an alarming gloss on the character of the species as a whole" (Cohen 84). Increase Mather speaks directly to the congregation in his sermon "The Folly of Sinning" (1699), delivered at the execution of Sarah Threeneedles for concealment: "Sin is such a serpent; it will fling thee to death 
if thou dost not make haste to get clear of it. To delay this matter is dangerous folly. If Lot had delayed his going out one day longer, he had lost his life. So has many an unhappy man lost his soul, be delaying his repentance one day. Oh stay no longer lest haply the day of grace should be ended, and the door of mercy shut against thee" (94-95). Not only is Mather warning the congregation of the danger of not acting immediately, he uses Lot as an example, who would have been familiar to listeners because of his deliverance from Sodom, but also because his wife was turned to a pillar of salt for her disobedience in looking back at the city. This kind of revelation was meant to warn the spectators/readers from committing the same crime, which was ultimately sin, but it also alerted sinners to the locus of sin at hand: the woman on the gallows.

Bosco uses Danforth's sermon at the execution of Benjamin Goad for bestiality to argue that execution sermons show how the sins begin small and then escalate in order to warn the community of their own connection to the criminal. Danforth suggests "that those who are publicly or privately committing the lesser sins of Goad's earlier life may be heading for a similar fate" (Lectures 158). As one would expect, this suggestion is made in the portion of the jeremiad known as the warning. But the numeration and escalation of sins in the life of the criminal is key to finding a commonality between the criminal and the community. Enumeration of smaller sins is also found in Cotton Mather's sermon "The Wicked mans Portion" delivered on the occasion of a servant convicted of murdering his master in 1675 . Bosco notes that the sin here is disobedience which is a threat to authority which leads to breaking the Commandments (Lectures 165). "Moreover, the federal doctrine of original sin provided the Puritan execution preachers with the rhetorical means to fashion a moral identification between the condemned 
criminal and the audiences on hanging day" (Seay 48). The minister's sermon provided the script for the unfolding drama on the gallows.

Returning to Foxcroft's sermon, he warns "our young people" from engaging in sin by saying "You appear lost to the reflections of reasonable creatures. Surely you have not the understanding of men: but may justly be compared to the brutes, that have no knowledge." While some may argue that the sermon addresses all young people and the use of "understanding of men" is a common reference to those who are educated and wise in the word of God, Foxcroft's choice of scripture comes from a portion of Proverbs that is part of a nine-chapter exhortation to young men. It's important to remember, from a previous chapter in this dissertation, that literacy was a primary tenet in order to have the ability to read the Bible. As a source of family reading in a home where literacy was encouraged and enforced by the community, scriptures and their position within the Bible would have been at the forefront of the minds of the gallows crowd.

Foxcroft's choice of Proverbs lends to the argument that his intended audience was young men. Scripture in the nine admonitory chapters of Proverbs include passages full of imagery of the ways young men should guard themselves from women:

To keep you from the evil woman, from the flattering tongue of a seductress. Do not lust after her beauty in your heart, nor let her allure you with her eyelids. For by means of a harlot a man is reduced to a crust of bread; And an adulteress will prey upon his precious life. (Proverbs 6:2426)

Young men's very lives were at risk from lustful behavior. And the temptress is so good at her skills. 
For the lips of an immoral woman drip honey, and her mouth is smoother than oil. But in the end she is bitter as wormwood, sharp as a two-edged sword" (Proverbs 4:3-4).

Proverbs makes it clear that young men are potential victims and the adulteress is the predator. Foxcroft chooses his scripture from this portion of warnings to elucidate his point about the adulteress:

He goeth after her straightaway, as an ox goeth to the slaughter, or as a fool to the correction of the stocks, till a dart strike through his liver, as a bird hasteth to the snare, and knoweth it is for his life (Proverbs 7:22). Though he does not include the remainder of the chapter, these verses would have been familiar enough for the community to make the scriptural connection and understand the meaning:

Hearken unto me now therefore, $\mathrm{O}$ ye children, and attend to the words of my mouth. Let not thine heart decline to her ways, go not astray in her paths. For she hath cast down many wounded: yea, many strong men have been slain by her. Her house is the way to hell, going down to the chambers of death (Proverbs 7:23-27).

These selections of scripture show the deliberateness of the woman, Folly, to mislead others. Daniel Cohen noted the final strokes of damnation: "Innate but willful human corruption and insubordination ... were both the ultimate and proximate causes of damning wickedness of sinners" (86). As mentioned before, the concealment statute describes the act of concealing a bastard child as "a great mischief." Rebekah, therefore, has been found guilty of being the mastermind of this mischief. Foxcroft is warning 
young men, potential victims of the seductress, to be wary of a woman's wiles, and he reinforces the justification for her punishment. The gallows crowd would have been intimately familiar with the transference of the symbolic to the literal. Hall shows how the permanency of symbolic language begins with the metaphor: "The archetypal source was Scripture. Its figures, tropes, and stories were echoed and reechoed in almost every kind of text that people came in contact with" (Worlds 69). Their world was shaped from the understanding of this symbolic language. "People relied on the Bible for the central metaphors and images of spiritual experience" (Hall, Worlds 121). Rebekah's presence on the gallows, as a convicted felon and a site of sexual experience, eliminates the metaphorical distraction of the adulteress and accepts the representation as the wily Folly of her scriptural counterpart.

As Foxcroft continues he chooses the parable of the initiations of wisdom and folly from Proverbs 9:17 and 18: "Stollen waters are sweet, and bread eaten in secret is pleasant. But he knoweth not that the dead are there; and that her guests are in the depths of hell." The female pronoun is used to name Folly and in the scripture she tempts the young man by saying "stolen waters are sweet, and bread eaten in secret is pleasant" to lure him. The images of the secret and the hidden, as in the depths of hell, are a general reference to nefarious behavior, but they are also what Rebekah has been convicted of. The carefully chosen scripture serves the purpose of warning young men against women but also warning the community of Rebekah as the symbol for the secret and hidden. Since the court already judged her and found her guilty of concealing an infant corpse, her body is identified as a site of sexual knowledge, but more importantly, her postpartum body is the source of the secret and hidden. Just as the scarlet letter " $\mathrm{A}$ " on Hester 
Prynne's dress marked her, Rebekah's body is marked by both her crime and her postpartum state. Ingebretsen argues that such an emblematic sign, typologically, points "elsewhere to subjects and possibilities unspeakably represented" (36). Here, Rebekah's body serves as representation of the typology Foxcroft's jeremiad invokes of secrecy, cunning ways, and concealed sins. Through the importance of sermon language as God's word embedded in the Puritan community, Foxcroft, with his metaphors and associations infused with scripture, serves as God's magistrate. And the effect of Foxcroft's speech was as powerful as any scripture: “... hearing was like reading. The response was essentially the same - a rush of feeling, a moment of sharp self-awareness. A new sense of obligation, and all because these people thought of sermons as equivalent to the very speech of God" (Hall, Worlds 42). It's not just Foxcroft warning the young men; their reaction and self-awareness was as potential victims of a seductress.

The preface to Thomas Foxcroft's 1733 execution sermon is a plea to the reader to be disciplined in the reading and "after you have read it, you would allow yourself time to think on what you have read, and enter into a solemn debate with your own soul thereupon (Lessons of Caution). Discipline meant self-discipline to these men: "it defined personal toughness and self-control the settlers felt they needed for overcoming weaknesses" (Elliott, Power 24). Part of this self-discipline was achieved through selfexamination "as a practical method for improving the individual and the society, not as a way of fostering an undue sense of guilt and doom" (Elliott, Power 24). This is an important observation to bear in mind when making sweeping generalizations about the tone of Puritan sermons for two reasons: one, the message was not necessarily one of pending wrath as some would characterize it, but of encouragement and self-action; two, 
a closer consideration of the concept of weakness when referring to male or female weaknesses to consider who is the subject of the sermon. As the jeremiad moves from the objective to the subjective, the drama created at the gallows provides an opportunity to visually examine if the postpartum body of Rebekah plays a part in the self-examination by the Puritan community.

The key to the gallows drama that make these events uniquely Puritan is the connection to the community's covenant with God that makes the sin of one, the sin of all. Bosco points out that the very concept of the formation of the colonies was that the community functioned as "one" in a covenant with God ("Lectures" 163). That covenant, as described earlier in this dissertation, is the promise of God to all mankind through Abraham. ${ }^{70}$ Frequently the church is termed as the body, where all members are a part of the body. The use of the term body is one the Puritan community would have seen as truth because of the scripture that defined it. In this way, execution sermons were directed at the criminal but, in the end, carried the greater purpose of connecting to the community, particularly those gathered at the gallows. Ministers relied on the correlation between crime and sin: a correlation that was well establish by the Puritan doctrine of original sin. "This doctrine furnished Puritans and their immediate heirs with a readymade explanation for the origin of criminal behavior: the depravity resulting from Adam's initial act of disobedience has been imputed to all of his descendants" (Seay

\footnotetext{
${ }^{70}$ And I will establish my covenant between me and thee and thy seed after thee in their generations for an everlasting covenant, to be a God unto thee, and to thy seed after thee. And I will give unto thee, and to thy seed after thee, the land wherein thou art a stranger, all the land of Canaan, for an everlasting possession; and I will be their God. And God said unto Abraham, Thou shalt keep my covenant therefore, thou, and thy seed after thee in their generations. This [is] my covenant, which ye shall keep, between me and you and thy seed after thee" Genesis 17:7-10).
} 
48). ${ }^{71}$ The criminal represented the potential for all to slip from salvation to sin. And if one slipped, the entire colony was in danger.

Jodi Schorb, in "Hard-Hearted Women: Sentiment and the Scaffold" (2013), argues that "executions' gendered power shapes its power affects, its ability to reproduce an affective response in the condemned and in those watching his or her execution" (291). This research seeks to show the same premise, except the affect at the gallows of Rebekah Chamblit convicted of concealment results in a particular affect. When the jeremiad moves from the pulpit to the center of town it essentially becomes decentralized, both physically and metaphorically. The physical place of the jeremiad is no longer central to the meetinghouse, the audience is no longer centered within the meetinghouse, and the jeremiad no longer centers its reasons on the community. Therefore, its affect becomes decentralized too. Rather than functioning as a traditional jeremiad, the evidence Foxcroft uses in the reasons are less about the community's sins and shift from the objective to the subjective, ${ }^{72}$ with Rebekah as the subject. For Schorb, the properly chastised body of the criminal evokes a communal identification with the audience that reassures the society of the possibility of redemption ("Hard-Hearted" 292). ${ }^{73}$ I argue, instead of signaling for the community's repentance, as jeremiads did originally in the

\footnotetext{
${ }^{71}$ Seay notes that that the doctrine conceived of in the 1620 s reached a level of orthodoxy with the adoption of the Westminster Confession of Faith (1647) when the Reforming Synod (1679-1680) reaffirmed Massachusetts Congregationalism's commitment to the doctrine. "As a result, the historian would be hard pressed to find a Puritan on either side of the Atlantic who did not at least formally declare his or her belief in the federal doctrine of original sin, because it was enshrined in the creeds and confessions of AngloAmerican Puritanism" (50).

${ }^{72}$ As discussed in chapter 2: "The subjective preempted the objective: a universal anxiety and insecurity had become no longer something which, being caused, could be allayed by appropriate action, but rather something so chronic that society could do nothing except suffer - and perpetually condemn itself" (Miller, The New England Mind 28).

${ }^{73}$ Schorb's premise is that the changing attitudes about the body result in the community seeing a woman's nature as more passive and her goal is to show how the audience identifies the woman on the gallows as a "hard-hearted" and therefore unnatural woman.
} 
meetinghouse, this decentralized jeremiad locates Rebekah and her postpartum body in the application to serve as the symbolic threat of power whose removal atones for the entire social body rather than creating a "window to the soul." Rebekah's Declaration, Dying Warning and Advice not only works to alleviate the community of blame. It is the addition of the execution narrative, Rebekah's declaration, that makes her accountable for her death and removes the culpability of the community.

Schorb also argues that the changing attitudes regarding females as being prone to temptation were shifting in the period between 1690 and 1780 to a rhetoric of a biological nature that made females more passive and resistant to temptation ("Hard-Hearted" 292). While this shift may occur at some point in that ninety-year window, Else L. Hambleton, in Daughters of Eve: Pregnant Brides and Unwed Mothers in Seventeenth-Century Massachusetts (2004), points out that a Puritan redefinition of femininity resulted in a conflation of femininity with chastity, and the laws of Puritan Massachusetts supports that conflation (xiii). Rather than take sides, my argument remains that when a woman is proven by the court to have been unclean and to have concealed the death of her bastard child, and her character is proven by the minister's sermon to have been among the wicked and she willingly left God, any notions of female passivity and restraint are moot. As Rebekah stands on the gallows guilty of concealment her female nature has been judged already. Foxcroft's decentralized jeremiad, with the use of metaphors of harlot and secrecy, combined with the gallows drama of a postpartum body on the scaffold, and the addition of Rebekah's 'dying words' in hand function to break the 'window to the soul' established by the tradition. The tools of execution work together to remove the community’s culpability. 
Narratives or 'dying speeches' were even more popular than the sermons or the hangings, and had the ability, in print, to leave a more lasting impression on the readers. They were highly valuable to both ministers and the community because they were considered truthful and often helped to clarify issues of guilt (Cohen 10). Daniel Williams, in an account of the criminal conversion of Esther Rogers, claims conversion narratives "appealed to New England readers on both sacred and secular levels...care was taken not only to enhance the spectacular effects of grace, but also to stress the symbolic function" ("Behold a Tragic Scene" 828). The conversion narrative not only reminded the community of God's saving grace but also of their relationship to the colony. The purpose of the conversion narrative, though unable to assuage death for the criminal, was to remind the colony that "if even such a wicked sinner as Esther Rogers could be saved, then surely grace was still possible for every individual, even for New England itself" ("Behold a Tragic Scene" 829). Williams goes on to note that of the twenty-one of the twenty-seven execution sermons produced between 1700 and 1740 included a criminal narrative. Of those, eighteen are conversion or redemption narratives ("Behold a Tragic Scene" 829). "Confessions were such an integral part of the humiliation process...ministers attempted to re-create in print the spectacle of the criminal's confrontation with death" ("Behold a Tragic Scene" 835). Confessions were often lengthier and more detailed than dying speeches and were publish after the execution. Their effect is arguably a different one than the effect a dying speech of an unrepentant criminal has on the gallows crowd.

Rebekah's declaration functions as such by readdressing the same topics that Foxcroft himself sermonizes on prior to her execution. It is also my argument that, 
purportedly "taken from the mouth" of the condemned, these statements of warning and dying advice also serve to reinforce a disassociation and relieve the community from their connection to the condemned. Rebekah's declaration begins by attesting to a very virtuous upbringing by her parents and her acknowledgment of the wisdom of God and her acceptance in the form of baptism, referencing Foxcroft's address to those who sin with the knowledge of sin deserving the worst of punishments. She quickly moves on to professing her guilt in the "Sin of Uncleanness" somewhere around the age of eighteen or nineteen, indicating her sexual sin. After this introduction, Rebekah's declaration gives a brief account of the crime of which she was convicted: just as Foxcroft focuses on her sexual sin rather than her crime, so does Rebekah's declaration.

Rebekah's declaration states "I therefore own the justice of God and man in my condemnation ... I am verily persuaded there is no place in the world, where there is a more strict regard to justice than in this province," which functions as an acceptance of her sin and reinforces the justification of the magistrate's sentence and the minister's message. Reis, finds that women associated themselves with their vile natures and they believed that their natures, which were "completely under the devil's dominion" (39), rather than their sins would carry them to hell; meanwhile, men distanced themselves spiritually from the sin they committed (Reis 13). Essentially, women would see their acts as evidence of an internal flaw, while men would rationalize their acts as being a product of Satan's work and temptation. Through the most pessimistic clerical perspective, women's identities and subjectivities were formed with ecclesiastical concepts and affected the way women received the sermon: internalizing the message of sin and Satan (Reis 12-13). The embodiment of the Puritan theology of damnation was a 
very real thing for women who lived under the expectation that their body was a sanctuary for sin. Religious scholar Mary Ann Stenger, in "Feminist Philosophy of Religion" (2002), suggests that male and female categories are used in social-cultural norms of behavior, and defined by patriarchy, and we are socialized at birth to understand these differentiations as limiting spiritual understanding. She argues that a feminist analysis of religious experience should also recognize these differences in order to provide a basis for recognizing difference in women's spiritual experiences (Stenger 150151). Acknowledging women's religious experience as different from men's allows us to examine yet another way that women's connection to the body makes them susceptible to the constructs of gendered crime in Puritan Massachusetts. Stenger shows how a feminist approach to religion reveals a dualism that identifies males with reason and females with the body (149). The abstracting of minds from bodies is a common method for discussing religious experience and encourages the transcendence of the body in order to attain enhanced spiritual enlightenment. “Given Western society’s focus on the body, especially female bodies, and the social roles and definitions assigned on the basis of bodily differences, feminists reject both explicit and implicit patriarchal understandings of the body and envision new, more positive meanings of body" (Stenger 152). In Puritan Massachusetts, the patriarchal function of Rebekah's body would have been to remind the crowd that her sin, and thus her crime, was not a single act but a result of her inability to transcend her body for a spiritual experience.

The gallows were scenes of high passion for both the ministers and the community. Coupled with the sight of a criminal on the gallows, and hearing it read aloud, the printed speech would have had an even greater affect on the crowd. This 
tradition of reading aloud things of the utmost importance reinforced two established edicts in the Puritan community: the power in the written word and the symbiotic nature of reading, hearing, and seeing. John the Apostle, emphasizes the connection between these three things because John witnessed the angel sent by Christ, and could testify to the things he heard and saw, allowing him to speak with authority when he says "Blessed is he who reads and those who hear the words of this prophecy" (Rev 1:3). Because John saw the messenger from Jesus, he bears witness to the authority of the words that are read and heard. In this way, seeing in the Puritan understanding, was to see to see the truth of something. At the gallows, the criminal narrative, Rebekah's "dying words," read aloud and in the hands of the crowd, coupled with their witnessing her on the gallows creates a sort of truth that aids the ministers in locating the threat to the colony in the body of Rebekah.

Scholars have argued that the addition of the criminal narrative plays a pivotal role in the gallows drama because it fulfills two functions: the criminal's acceptance or acknowledgement of the crime in the narrative reinforces the minister's condemnation of sin and reestablishes his own waning creditability; and, the narrative functions as the means for expelling sin from the colonial body. This scholarship is essential to my argument that the sight of the criminal on the gallows creates a physical connection between the criminal and the colonial body to argue for special consideration of the postpartum body of an infanticide criminal. An analysis of Rebekah's situation using this feminist philosophy of religion reveals concealment as not only a gendered crime but also how female embodiment harnesses Rebekah, and the male awareness of her, to her body. While the act of illicit sex was the sin performed by the male, the woman's body is her 
sin. His body does not carry the sin and is therefore still redeemable and able to participate in a transcendent spiritual experience. Rebekah's body was the sin and her postpartum body carried the proof.

A coherent chain of sin and misconduct also aided ministers in their attempt to link the criminal to a multitude of sin. As Cohen points out, the Puritan theological understanding of sin consisted of God's grace saving individuals from their own universal depravity (82). While God's restraining grace could save or damn anyone, a woman's sexual behavior was the gateway to her total depravity. "According to Puritan ministers, it must have been because the sinner's residual wickedness eventually caused God to withdraw his restraining grace" (Cohen 84) leading to God's abandonment of a sinner who is ultimately seen by the community as unredeemable.

Foxcroft uses Job 36:18 for his sermon, "Because there is wrath, beware lest He take thee away with his Stroke: then a great ransom cannot deliver thee." Yet Foxcroft, when addressing Rebekah near the end of his sermon, states, "a provoked God did not by his own immediate hand cut you off with a stroke" and adds that Rebekah should "accept the punishment of your iniquity," showing that God's action was not to strike her down; it was her own depth of sin that caused her demise. Ministers believed in an intimate relationship among sins and a natural progression that led a sinner to commit more sins (Cohen 87). In addition, identifying the repeated misdemeanors allowed ministers to essentially prove the wickedness of the criminal was more than an idle venture into sin, especially into carnal sin. "The idea that God's fluid restraints on wickedness might be calibrated to the morality of each person's past worldly conduct provided a theological explanation for the wide range of behavior found even among the unredeemed" (Cohen 
86). In other words, the linked concepts of restraining grace and "sin punished by sin" helped make theological sense of the vast expanse of human conduct that lay somewhere between visible sainthood and palpable damnation. Rebekah's declaration confesses many sins such as: ignoring the Sabbath; entering into uncleanness; neglecting her prayers; and lying to conceal her sin. This progression of sin and assumption of sinfulness also played its part in the dispensation of colonial law. Puritan magistrates did not distinguish the facts of a crime from the character and nature of the crime: "And if they saw certain types of women as especially prone to sin, their laws would seek out and smite the sin behind the crime" (Hull 28). Rebekah's crime was arguably not the critical issue. Foxcroft's continual symbolic references to her postpartum body illuminates her true sin is conception and then her refusal of conception.

Though Cotton Mather was not the first or the last to use this theology of divine abandonment, his successful harangue at the conviction of a female infanticide was repeated by Foxcroft against Rebekah. Cohen notes that the "sin as punishment for sin" doctrine was rarely used in sermons but the theological argument of divine abandonment was used throughout the eighteenth- century (Cohen 87). In light of the easy association of women with sin shown earlier, and how her whore conversion is completed with one sexual act, God's abandonment provides useful ammunition against women and further supports the community's disavowal. Rebekah's own declaration, as much as it can be considered her own, continues this appropriation of guilt and God's just abandonment. If the general public could associate themselves with the sin of the condemned as Williams suggests (Pillars 5), or be forced to recognize their "kinship" with the offender as Cohen suggests (84), then a closer analysis of the Rebekah asserts the possibility that there is a 
disassociation of the gallows crowd from Rebekah. Unregulated sex was implicitly gendered female, her postpartum body is undeniably female, and the genealogy of biblical women and female involvement with sexual filth produced by Foxcroft signals Rebekah as a "living border of sexual deviance" (Hull 125) that threatens the community. Rebekah's death not only removes the threat, but her declaration also relieves the community of any further need for atonement.

Both the theological framework of "sin punished by sin" and the natural progression of sin are reflected in Rebekah's declaration: "and as the sin of uncleanness has brought me into these distressing circumstances" and "I found by experience, that upon my leaving God, he was provoked to forsake me, and at great length suffered me to fall into that great complicated sin that has brought me to this death.” She continues to stress that it was her own behavior that caused God to leave her: "mind me, I first left God and then he left me." Rebekah's declaration relates the security she felt in herself a year ago with the crowd "as many of you now do" just as Foxcroft warned in his sermon of the swiftness of punishment "but by woeful experience I have found, that lust when it has conceived bringeth forth sin, and sin when it is finished bringeth forth death." This portion of Rebekah's declaration, from James 1:15, alludes to her postpartum state: "that lust when it has conceived bringeth forth sin," suggests that it is the pregnancy that is the sin. The death, her death, the gallows crowd gathered to witness was not the only death in their minds. Still fresh from the sermon, Foxcroft's language of motherhood and concealment asked the community to recognize that Rebekah's path has led to her illegitimate pregnancy. The nature of her crime and her gender help to distance the men in the community from any connection to the crime. As mentioned before, Puritan men 
had a tendency to separate the female soul from the male self and "men seemed to differentiate what or who they were from what they did" (Reis 39), while "women embraced a sense of themselves as essentially depraved, as sinners bound to the devil" (Reis 63). This division between male and female religiosity also enabled men to see women differently and, more importantly, to see women's crimes as being particular to women. Thanks to her innate moral depravity, Foxcroft's convincing rhetoric, and the declaration taken from her mouth, Rebekah is the one who conceived the sin.

Though the jeremiad would traditionally seek a universal atonement, a decentralized jeremiad warrants an alternate deconstruction where the nature of her crime and her gender change the typical application. Rebekah's botched character and her polluted body now become a symbol of uncleanness and her postpartum body is evidence of her conception of sin. Though infanticide is a crime of murder, on the gallows, Schorb argues that sex is on trial. "Unlike other crimes ... infanticide sexualizes the woman's body (mostly young, mostly unmarried) as a site of sexual knowledge" ("Uncleanliness" 73). The fact that Rebekah was sexually experienced, as evidenced by her postpartum body, sent her plummeting to the category of whore. But her status as sexual deviant is overshadowed by the evidence of her postpartum body as the site of conception: "that lust when it has conceived bringeth forth sin, and sin when it is finished bringeth forth death." Her declaration acknowledges her conception was a result of lust and the conception ended in death.

While sex, sexuality, and concealment are all acts that can be participated in by men, the crime of concealment was overwhelmingly female and the sight of a postpartum woman on the gallows reinforces the femaleness of the crime, the sin, and the assumption 
of her guilt. While discussing witch trials, John Demos argues that true guilt no longer matters: "What does matter is that many of them were believed to be guilty, and that this belief was itself efficacious. As anthropologists have observed in cultures around the world, people who think themselves bewitched are vulnerable to all manner of mischance [and] occasionally they sicken and die" (Entertaining Satan 9). Women in Puritan society, who are ritually characterized in scripture as the source of temptation, trickery, and lustfulness, begin to embody the language used against them.

Linguistic anthropology theory helps us understand how language is produced and how the language, as constructed by the dominant group, shapes the way the community receives the message within the infanticide sermons and narratives. According to John J. Gumperz and Stephen C. Levinson, in "Rethinking Linguistic Relativity" (1991), language functions within a given community as both a display of power and a tool for the reproduction of power at the subjective level of the individual. They claim that "there is a very special kind of domain of discursive practice and externalized cognition that lies in some sense between the inner life of the mind and the outer world of objects and behavior, partaking of both" (614) meaning the use of the language forces the listener to understand the meaning somewhere between their own mind and their world. Specifically, they claim that "aspects of meaning and interpretation are determined by culture-specific activities and practices. Those activities and practices are interconnected in turn with the larger sociopolitical systems that govern and are in turn in part constituted by them" (Gumperz and Levinson 614). In fact, new studies of the sermon by Meredith Marie Neuman argues that the creation of sermons is a "discursive process that involves the entire community in the twined endeavors of scriptural explication and the 
material dissemination of that exegesis" (x). The community plays as much of a role in helping to explain scripture and to create and reaffirm meanings as the minister does in the production of the sermon. "Sermons depend not only on the divine efficacy of scripture, not the conscientious efforts of the minister, nor the soul searching of the auditor; rather, the production of sermon literature - the composition of texts, the application of meaning, the material and textual preservation of words - becomes a shared goal of an entire community of Jeremiah's scribes" (x). The experience of sermon culture is just as important as the production of the texts themselves. "Sermon culture, by contrast, is an entire set of practices that produce not only texts (sermons proper as well as non-sermonic writing, especially history, biography, and anecdote) but also material artifacts (printed sermons, notes, copies, and transcriptions). The production of sermon literature by both clergy and laity is material as much as it is textual" and a full understanding of the culture helps us understand the "the phenomenal event of the sermon and its subsequent dissemination in the lives and texts of the community" (Neuman 8).

Arguably, we can't know what was said in common, everyday use but what we can say about Puritan Massachusetts is the importance of God's word was the defining powers of meaning for the community. As the jeremiad shifts from objective to subjective, we must question how the audience hears the language and makes sense of their understanding of it and its activity specific use. Nowhere was symbolic language more effective than in the development of crime literature in early America. When the symbolic language focuses on Rebekah's postpartum body, the message is no longer steeped within the text but on the external as well. 
Typically, if the criminal plays their part in the gallows drama, "members of the audience would see in the sinner a window to their own soul, and pangs of terror and regret would cause them to reflect upon their own sins" (Schorb, "Uncleanliness" 82). ${ }^{74}$ Yet, this research has argued that Foxcroft's sermon generates the symbolic language that targets Rebekah specifically, making the jeremiad less universal. The gallows crowd is led by Foxcroft to see specific aspects of Rebekah's sin, and his choice of metaphor is whore and mother and harlot. While the language of the sermon is symbolic it is also very literal when addressed specifically to Rebekah. Foxcroft's sermon and Rebekah's declaration not only function to assign and accept the threat to the community, they also have the power to keep men from identifying with the sinner on the gallows.

The use of the concealment statute in Puritan Massachusetts is a phenomenon. While it carried no biblical counterpart, the statute was still codified into Massachusetts law. "So the ultimate moral would seem to be that though our seventeenth-century forebearers would be nothing without proofs from Holy Writ, yet as between one array of proofs and another, they could find it convenient to choose that which was the more compatible with their mundane interests" (Miller, "The Half-Way Covenant" 712). Unlike murder convictions, the statute placed the burden of proof on the criminal to prove she had not committed the crime. Hoffer and Hull note that circumstantial evidence is what prevailed in convictions for concealment rather than proof. They argue that this circumstantial evidence comes directly from three precepts in the larger Puritan conception of sin: the concealment of sin; previous sexual behavior; and "the disobedience of women to community standards" (Hoffer and Hull 49). The language of

\footnotetext{
${ }^{74}$ Schorb argues that the infanticide narrative and the entire gallows theater is nonnormative because Katherine Garrett is a Native American woman.
} 
the statute is used by the court to convict Rebekah, the precepts are used to convince the gallows crowd to condemn her. For the precept of concealing sin, Foxcroft's sermon has ample evidence of his preoccupation with concealing by using the language of secrecy and hiding. For the precept of prior sexual behavior, Rebekah's own declaration confesses to her previous behavior. But what fulfills the third precept of disobedience? What makes Foxcroft so vehement in his language and conviction of Rebekah? This dissertation previously explained that ministers expressed their own personal anxieties through their sermons. Early ministers and lay preachers, such as John Winthrop, expressed anxiety over their covenant and being mistaken for Separatists. The following generation of ministers agonized over the community's inability or unwillingness to prove themselves regenerate among the influx of non-Puritans. Other ministers took up the lax morality of drunkedness or laziness. All of these anxieties pointed toward their inability to control their colony. While the idea of sinful natures is part of the connection that Foxcroft tries to make, he seems particularly annoyed, even angry ${ }^{75}$, about having to deal with more issues they cannot control: public acknowledgment of intimacy and the reproductive rights of a woman's calling to motherhood. Her ability to control being a mother disrupted the social order of the community.

For the Puritans of Massachusetts, a functioning community was not only in keeping with their covenant but it secured their daily lives. Wall suggests that a look at the physical layout specifically of New England towns, with clusters of homes and a central village green, is to understand the sense of communal ideas that structured the Puritan town. "The community provided a cohesive force ... seeking and occasionally

${ }^{75}$ Hall argues that anger "infiltrated every effort at affirming moral boundaries" (Worlds 20). 
achieving stability, order, and cooperation" (Wall 1-4). For that reason, members were encouraged, even enforced, to understand and maintain their roles. Wall suggests a sort of early neighborhood watch system was in place to police the community members through keeping a good opinion of one another (14). "No one could ignore the community opinion because it mattered so much for an individual's well-being” (Wall 30). Poor behavior was disruptive to the health of the community. Neighbors helped to keep one another in their proper sphere once they understood their role in the community. Part of understanding that role was understanding one's calling.

Edmund Morgan's discussion of the Puritan family reveals three ways a calling was interpreted. A calling "always implied that someone called and that someone else was called" (Morgan, Puritan 69). The caller was always God and it was always man being called. "In the first and broadest sense God called a man to every right action that he did." In this way, a man could claim he was called to it when things were right, and when he was in doubt he could say "he felt no call to it" (Morgan, Puritan 69). It's important to remember the way that the community understood God's word. To be called was not just a figurative way of responding. In the Puritan understanding of language, a calling would have been a direct message from God and would have required a real, literal response of action. This form of calling provided a common usage that either affirmed someone's action was right or was wrong. It also carried the tone that reaffirmed the rightness of God's decisions since he was the subject of every calling. It gives no credit to the individual for the action but to God alone. However, the common use of this sense of calling does seem to credit an individual who claims to have been called to it with obedience to God. 
In the second sense, "the word applied to the process of salvation: God "called men to salvation" known as effectual calling (Morgan, Puritan 70). It is important to remember that Puritan religion functioned on a system of election. One was never sure of one's election and Perry Miller points out that they waited on God for action: "So, until a man experienced effectual calling, he did dwell in impotency of the spirit, prostrate before God, unable either to lift or to wish to lift a finger for his own salvation" (Miller, "The Half-Way Covenant" 684). This effectual calling, and the ability to prove regeneration that came with it, was the source of the arguments for the Half-Way Covenant in order to address dwindling church membership.

In the third sense, a particular or personal calling described the occupation of a man. A man received a particular calling by two rules: that his occupation serve both God and society, and his occupation be recognized by God's awarding of talents and inclination. A boy would likely be expected to choose an occupation between ten and fourteen but girls, whose options would have been limited by the expectation of being nothing more than a housewife, began training for their particular calling much younger (Morgan, Puritan 67-71). However, Elliott points out that John Cotton believed there was an "intimate connection between one's practical calling and his spiritual calling. Cotton argued that every Christian's spiritual calling charges his earthly vocation with such dignity" (Power in the Pulpit 25). So, a boy could only hope to be called to the right occupation as evidence of his particular calling and his success in that occupation depended on his effectual calling.

With such a limited expectation, a girl's training and education, beyond the daily duties of the house, would have consisted of an education for being a good woman, being 
a good female. Conveniently, her particular calling and her effectual calling are the same. Laura Thatcher Ulrich, in Good Wives: Image and Reality in the Lives of Women in Northern New England 1650-1750 (1982), discusses how essential women, good wives, were to the community and their description had a biblical connection. All aspects of female life "can be found in idealized form in the Bible in the description of the "virtuous woman"' (14). Non-ideal behaviors in the Puritan community constituted being bad and many of them were specifically of female behavior. While taking God's name in vain, drunkedness, gossip, and several other behaviors were less than ideal and could be committed by men, women were frequently charged with offenses that suited their natures or fit the "weaker sex." 76 "At least 2,954 women were charged with 3,276 offenses in the several county and colony courts. More than one-fifth of these offenses can be viewed as severe violations of the female sex role. The authorities prosecuted 393 female offenders for refusing to be passive and deferential" (Koehler 190). A variety of offenses existed but not all of them were prosecuted with equal vigor.

Among these idealized aspects of femininity, chastity was paramount to her virtue. "All other facets of their personalities that might make them enviable wivestheir housewifery skills, character, or beauty were subordinated to their reputation for chastity" (Hambleton 7). While male and female sexuality would need to be governed, female sexuality took precedent in Massachusetts, and misbehavior was punished. Female fornication account for 38 percent of female crime: "Indeed the state (Massachusetts) prosecuted females at a rate that was three times higher than that at which it prosecuted males" (Saxton 36). Arguably, the real threat of female fornication

\footnotetext{
${ }^{76}$ Several scholars use the term weaker sex to describe women in Puritan society (Hull 10; Koehler 2).
} 
was pregnancy; something men, whose bodies do not bear the proof of sexual behavior, didn't risk. Since motherhood was an expectation that could be tied to her practical calling, the role of motherhood needed to be protected within the sanctions of legitimate marriage. Furthermore, once pregnant, a woman would naturally be expected to become a mother. Any disruption to that was a disruption to the community. While Hull doesn't address a woman's calling, she does claim that "Infanticide and child murder struck at the foundations of the domestic roles of women and the structure of family" (47). To deny her pregnancy by concealment, I claim, denied her practical calling.

While concealing is a serious threat to the stability of the community and to their covenant, it had a different meaning for women. By the very nature of her female body, she could conceal her sin and her pregnancy from her neighbors, but also because "Concealment includes not only secrecy and deception, but also reticence and nonacknowledgement" (Nagel 4). Infanticide is a way for her to refuse to acknowledge her calling to motherhood. Koehler doesn't consider a woman's calling either, but he does argues that "By Calvinist standards, the child-murderer sinned against much of what a woman was supposed to be. Through infanticide, the mother denied that for which God had reputedly made her - the conception, bearing, and care of children. She was not simply killing another person, but actually nullifying her own existence as a woman" $(201-202) .^{77}$

The downfall for the woman convicted of concealment is that she has failed in all three senses of her calling. Because God would never have called her to do the wrong

\footnotetext{
${ }^{77}$ While I share Koehler's argument, he suggests that infanticidal mothers were acting out of a desire to control their own lives and a need for retaliation (Koehler 202) he does not suggest a woman is in violation of her calling.
} 
things, she has to admit that she was disobedient, she turned away from effectual calling for salvation, and she has failed in her particular calling to be a good woman. It seems, to our contemporary mind, that a community would not take her refusal of her calling so personally. Yet, community was the heart of their daily life and their covenant and "when their sense of goodwill was violated" people were angry (Hall, Worlds 20). Rebekah's declaration takes great care to list all the ways she was supported by her community. "I was tenderly brought up, and well instructed in my father's house" and even credits being "under very sensible impression of the spirit of God."

While her account is not necessarily a confession, she does acknowledge the justice she has received. Her declaration continues with "I have none but myself to blame" and expresses specifically the "young people, and more especially those of my own sex" about how easily they may fall. Her declaration acknowledges "I had the advantage of living in several religious families" but that she failed to keep their instructions and warnings. Though her own situation has ended this way, her declaration still advocates for the same opportunities she had in order to absolve the community: "And I would advise those of my own sex specifically, to choose to go into religious families, where the worship and fear of God is maintained." Scholars have argued the importance of the criminal conversion narrative, like those of Patience Boston, Katherine Garret, and Esther Rogers, within the criminal literary genre because they are more effective for creating the 'window to the soul' for the audience. Yet, this dissertation has shown the symbiotic way that Foxcroft's sermon and Rebekah's declaration function to target her postpartum body which warrants a revaluation of other cases of concealment in Massachusetts beyond their traditional readings. This connection between gendered 
language can be found in the case of Anne Hutchinson. John Winthrop, obsessed with proving the prosecution of Anne Hutchinson was warranted, investigated the miscarriages of Anne and her friend Mary Dyer as evidence of God's agreement. "The Court had to now deal with the head of all this faction, a woman had been the breeder and nourisher of all these distempers," Van Engen remarks, "Such language of breeding and nourishing linked the court case to Winthrop's notorious interest” (104). Similarly, my goal has been to connect the gendered language of the sermon and declaration to the literal body of Rebekah. 
CONCLUSION

\section{THE PURITAN INFANTICIDAL PREGNANCY}

"Sufficient unto the day is the evil thereof" Matthew 6:34

The starting point for this research was an archival project inspired by a collection of essays edited by Janet Moore Lindman and Michele Lise Tarter, A Center of Wonders: The Body in Early America. The essays' methodologies range from medical to anthropological to historical, but all of them are focused on reimagining the body: its uses; its significance; its meaning. Our Puritan origins still generate a kind of wonder for our contemporary minds. We see resurgent fundamentalists using the tenets of Puritanism for support, perceived Puritan discipline fuels arguments about the need for laws that govern society, and the anxious Puritan spirit is echoed in the fearmongers of the twentyfirst century. In A Center of Wonders, Kathleen Brown's essay, "Murderous Uncleanness: The Body of the Female Infanticide in Puritan New England" examines Cotton Mather's sermon Warnings from the Dead at the execution of Elizabeth Emerson for the infanticidal death of her twins. Brown's research focuses on Mather as much as it does Elizabeth and her crime, but the real subject of Brown's essay contributes to the interdisciplinary scholarship embracing a critical perspective of the body, particularly of the female body. Published in 1693, Mather's sermon is the first of the infanticide texts. Brown discusses Mather's sermon as the start of a trend in literature identifying female bodies as the symbolic uncleanness of the colony. My research was driven by two claims 
made by Brown: Mather's exhortations on the dangers of bodily pollutions in the pulpit inspired his execution sermon, and infanticide was a way for ministers to redeem themselves after the witch trial debacle. If these arguments were true, what could be discovered in an analysis of other infanticide sermons. My own investigation led me to Rebekah, whose narrative comes at the end of what is termed the infanticide phenomenon.

Rebekah Chamblit, convicted in 1733 for concealment, presented the opportunity to examine both a jeremiad and a criminal declaration together as crime literature that occurred sixty years after Elizabeth Emerson. The expectation was that having these printed materials from Rebekah's case, the last of the printed sermons and declarations from Massachusetts, would somehow help reconstruct one story of concealment in Puritan New England. Paul Ricouer, in The Reality of the Historical Past, claims historians are able to pick and choose the documents that help reconstruct the past and aid in the explanation of their epistemological quest (39). Even with the archival material, I quickly discovered that no history could be written about the women convicted of concealment, and Rebekah's case is no different. Their silence makes it impossible to know them. Instead, I have attempted to take an interdisciplinary approach to the formation of the Massachusetts Bay colony and the tenuous power of the men who built it in order to frame the conviction and condemnation of Rebekah Chamblit. Her story, however, is still unknowable.

Thomas Foxcroft's sermon Lessons of Caution to Young Sinners, and Rebekah's Declaration, Dying Warning and Advice are part of a much larger picture of Puritan anxiety in which ministers and magistrates struggled to maintain control of their 
wilderness, their charter, and their covenant. Johnathan Winthrop and his followers believed themselves to be God's chosen and believed that God had delivered them to the shores of New England in order to establish their promised land. While others would form their own colonies, my research began by making the case that Massachusetts Bay was different from the others in how they approached literacy, how they formulated their legal statutes, and how the creation of their Congregational Church defined them as a colony with the singular purpose of keeping their covenant with God. As times changed and new challenges presented themselves, every generation of Puritan ministers expressed their own anxieties for maintaining their covenant. Puritan exceptionalism led these men, in part, to fear the things they didn't know and couldn't control. Concealment caused great concern for these ministers and the incorporation of the 1624 statute for concealment was one effort to address the sexual sin of the colony. The statute helped assuage their anxiety by convicting and condemning women for more than six decades.

It is impossible to know the intentions of the justice system or the individual temperament of the legislators behind the 1624 statute in its conception in England or its incorporation in Massachusetts, but the implementation of the 1624 statute in Massachusetts Bay was particularly useful to the Puritan community because it emphasized the abhorrence for concealment and for murder. Many scholars have noted that if the evidence was the body of a dead infant, then the body also constitutes murder. Yet my research has tried to show how the act of concealing was considered morally reprehensible as well as a threat of the unknown. As Massachusetts Bay dealt with the threat of the revocation of their charter, the potential for Indian attacks, the declension of their colony, the influx of non-Puritans, and their own election to sainthood in addition to 
their obsession with witches, Satan, and pollutions, Puritans led anxious lives. Threats were both real and imagined in their wilderness. The proof of a threat was not always needed to suggest that there was one. A woman, newly delivered of a child and convicted for concealment, threatened the colony with her proven sexual history but also with her, and her body's, ability to hide her sins.

Rebekah's case is unique because access to both the sermon and her declaration allow for my argument that these two texts work together. This dissertation has suggested that the postpartum body represents a woman's ability to conceal her pregnancy and her sin. The language Foxcroft uses to identify the postpartum state of Rebekah's body, however, references a larger field of feminist scholarship. Women's studies has created a space for discussion about the public fetus, pregnant embodiment, and phenomenology of pregnancy. The experience of being pregnant has been coopted by public discourse about the fetus versus the mother and has prompted scholarship regarding motherhood as a social and political construct. This dissertation has shown how the expectation of women is to become a mother as part of her calling by God. Though the social body of Massachusetts Bay was governed by Puritan men, our contemporary culture also constructs women as potential vessels for reproduction. The lack of universal access to birth control and the support of health insurance benefits for fertility treatments prove that we still encourage a pronatalist culture. Yet, these also prove that women still do not control their reproduction, and women's choices are part of public discourse.

The driving force behind this research has been my desire to constantly ask our community to consider how women's bodies are continually and unfairly placed at the center of debates about control. In her research with eighteenth-century infanticide cases, 
Sharon M. Harris finds that "cultural attitudes toward women [produce] women's desperate responses to their restricted lives" (Executing Race 20). Consideration of the years between 1733 and now reveals that women still struggle against cultural attitudes and women are still responding with desperation. Likely the most famous of concealed neonaticide in recent history is "Prom Mom" Melissa Drexler, who in 1997, delivered a baby in the bathroom during her high school prom after concealing her nine-month pregnancy from family and friends (Hanley). Since then, there have been numerous reports of similar incidents across the United States. Here in the Commonwealth of Kentucky, in April 2001, Angelita Turner was convicted of killing her newborn in her room at Murray State University. The courts found her guilty of manslaughter and several news sources condemned her through mention of her socio-economic status, an existing child as evidence of her previous sexual history at an early age, and her initial refusal to admit to having delivered a baby. In March 2010, an Iroquois High School student discarded the body of an infant later declared a miscarriage in the bathroom during school. Just this October, 2018, a baby was found in the bathroom in a high school in Prince George County, Maryland, and an investigation into the possibility of a still birth is underway. The "female who delivered the baby was found at the high school" (AP news) and charges will follow if there is enough to suggest her intent was to conceal the death of the infant. This isn't Puritan Massachusetts, but the postpartum body is still the evidence needed for concealment. Is it still a symbolic threat?

Feminist studies have resulted in scholarship that discerns the female from the feminine, and we are better for the defining differences. For Rebekah, and women of Puritan Massachusetts, to be female was to be feminine. Your calling was to be a 
goodwife and a good wife. So much of a Puritan woman's life was a paradox created by her body: a vessel of lustful temptation and a vessel for reproduction. Ironically, women today still struggle with the madonna/whore dichotomy of social expectations. What we don't learn from any of the archival materials available to us is the experience of carrying a child that results in a mother's conviction for infanticide. Historically, women's pregnancy experiences have been left out of literature. Iris Marion Young states, in "Pregnant Embodiment: Subjectivity and Alienation," that "We should not be surprised to learn that discourse on pregnancy omits subjectivity, for the specific experience of women has been absent from most of our culture's discourse about human experience and history" (46). Young's approach to existential phenomenology argues against traditional concepts presented by thinkers such as Merleau-Ponty, Lacan, and Derrida about the separation of the self and the body by embracing a phenomenology of pregnancy that credits the woman with subjectivity, as the one experiencing the body, rather than the object, the vessel carrying the fetus (52-54). Her goal is to call for an appreciation of pregnancy experience and she admits that her essay is restricted to the analysis of specific experiences of women in "technologically sophisticated Western societies" (47) but her goal enables us to think critically about women and concealment. If Young can argue for a re-conception of traditional reading of pregnancy experience, to be the subject of her pregnancy rather than be seen as the object, this dissertation suggests a need for an analysis of a woman's experience as a postpartum body and how the controls of society change with the change in her bodily status.

Rebekah's experiences were silenced by her community, Foxcroft, and the declaration "taken from the mouth" by Mather Byles. This dissertation has suggested that 
the powerful, symbolic language of the sermon and the plain-style declaration work to mutually reinforce Rebekah's postpartum body as a threat of a woman's ability to conceal and as a threat of her ability to control her own reproductivity, and thus refuse her calling in all three senses of the Puritan calling. While the affective response of the gallows sermon and declaration was to create a 'window to the soul,' the opposite occurs. Foxcroft's sermon functions to create a cultural narrative of disobedience, concealment, and deception in Rebekah's postpartum body. Her purported words reaffirm the minister's message and justify the public sentiment of disavowal at Rebekah's death. 


\section{REFERENCES}

Archer, Richard. Fissures in the Rock: New England in the Seventeenth Century. U of New Hampshire, 2001.

Arnold, David A. "The Type of Sham: Hester Pryne as Jeremiad" Pacific Coast Philosophy, vol. 27, no.1/2, Sept 1992, pp. 44-53. JSTOR. Accessed 19 Jan 2013.

Baldwin, Erik. "'The Devil Begins to Roar': Opposition to Early Methodists in New England." Church History, vol. 75, no. 1, March 2006, pp. 94-119. EBSCO. Accessed. 23 Oct 2016.

Barker-Benfield, Ben. "Anne Hutchinson and the Puritan Attitude toward Women." Feminist Studies, vol.1, no. 2, Autumn 1972, pp. 65-96. MLA. Accessed 16 May 2012.

---. The Horrors of the Half-Known Life: Male Attitudes Toward Women and Sexuality in Nineteenth-Century America. New York, Harper and Row, 1976.

Bartky, Sandra. "Foucault, Femininity, and the Modernization of Patriarchal Power." Femininity and Domination: Studies in the Phenomenology of Oppression. New York, Routledge, 1990.

Bercovitch, Sacvan. The American Jeremiad. U of Wisconsin P, 1978.

---. The Puritan Origin of the American Self. Yale UP, 1975. 
Bosco, Ronald A. "Early American Gallows Literature: An Annotated Checklist." Resources for American Literary Study, vol. 8, 1978, pp. 81-107. Project Muse. Accessed 25 Jan 2014.

---. "Lectures at the Pillory: The early American Execution Sermon." American Quarterly, vol. 30, no. 2, 1978, pp. 156-176. JSTOR. Accessed 24 Jan 2009.

Boyer, Paul and Stephen Nissenbaum. Salem Possessed: The Social Origins of Witchcraft. Harvard UP, 1974.

Brown, Kathleen. Foul Bodies: Cleanliness in Early America. Yale UP, 2009.

---. Good Wives, Nasty Wenches, and Anxious Patriarchs. U of North Carolina Press, 1996.

---. "Murderous Uncleanness: The Body of the Female Infanticide in Puritan New England." A Center of Wonders: The Body in Early America. Edited by Janet Moore Lindman and Michelle Lise Tarter. Cornell UP, 2001, pp. 77-94.

Browne, Arthur. Religious education of children recommended, in a sermon preach'd in the church of Portsmouth December 27th 1739. Being the day appointed for the execution of Penelope Kenny. By Arthur Browne, A.M. And missionary from the Society for Propagation of the Gospel in Foreign Parts. Published at the desire of the church wardens and vestry. 1740. Early American Imprints, Series I: Evans. Accessed 16 Aug 2006.

Chamblit, Rebekah.The declaration, dying warning and advice of Rebekah Chamblit. A young woman aged near twenty-seven years, executed at Boston September 27th. 1733. Early American Imprints, Series 1: Evans. Accessed 06 Nov 2006. 
Chapin, Bradley. Criminal Justice in Colonial America, 1606-1660. U of Georgia P, 1983.

Cohen, Daniel A. Pillars of Salt, Monuments of Grace. New York, Oxford UP, 1993. Constitution Society. "Massachusetts School Law 1642." Constitution Society. 23 Sept 2015. http://constitution.org/primarysources/schoollaw1642.html

Cotton, John. God's Promise to His Plantations. Early American Imprints, Series 1: Evans. Accessed 09 Sept 2016.

Dayton, Cornelia Hughes. Women Before the Bar: Gender, Law, and Society in Connecticut, 1639-1789. U of NC Press, 1995.

D’Emilio, John, and Estelle Freedman. Intimate Matters: A History of Sexuality in America. U of Chicago P, 1997.

Deeb, Katharine. "dare alla luce."Dare alla luce. dareallalucedoula.com/about/dare-allaluce-italian-verbtransitive-to-give-birth-to/

Demos, John. A Little Commonwealth: Family Life in Plymouth Colony. New York, Oxford UP, 2000.

Dickinson, J.R., and J.A. Sharpe. "Infanticide in Early Modern England: the Court of Great Sessions at Chester, 1650-1800." Infanticide: Historical Perspectives on Child Murder and Concealment, 1550-2000. Edited by Mark Jackson. England, Ashgate, 2002.

Duniway, Clyde Augustus. The Development of Freedom of the Press in Massachusetts. New York, Longman Green, 1906. archive.org/details/developmentfree02dunigoog/page/n10. Accessed 05 Dec 2017 
Earle, Alice Morse. Margaret Winthrop. Corner House, 1975.

Elliott, Emory. Power and the Pulpit in Puritan New England. Princeton UP, 1975.

Ford, Worthington Chauncey. The Boston Book Market, 1679-1700. Lenox Hill, 1972.

Foxcroft, Thomas. Cleansing our way in Youth. Press'd, As of the Highest Importance: And Observing the Word of God Recommended, As the Only Sufficient Means. 1719. Early American Imprints, Series I: Evans. Accessed 10 October 2015.

---. Lessons of caution to young sinners. A sermon preach'd on Lord's-Day Sept. 23. 1733. Upon the affecting occasion of an unhappy young woman present in the assembly under sentence of death. 1733. Early American Imprints, Series I: Evans. Accessed 06 April 2006.

Fuller, Margaret. Woman in the Nineteenth Century. New York, Dover, 1999.

Godbeer, Richard. Escaping Salem: The Other Witchhunt of 1692. New York, Oxford UP, 2005.

---. Sexual Revolution in Early America. John Hopkins UP, 2002.

Gramsci, Antonio. "Normative Grammar (1927-1935)." The Routledge Language and Cultural Theory Reader. Edited by Lucy Burke, Tony Crowley, and Alan Girvin. New York, Routledge, 2000. 280-294.

Gumperz, John J., and Levinson, Stephen C. "Rethinking Linguistic Relativity.” Current Anthropology, vol. 32, no. 5, Dec 1991, pp. 613-623. JSTOR. Accessed 5 Aug 2014.

Hall, David D. “The Uses of Literacy in New England, 1600-1850.” Printing and Society in Early America. Edited by William L. Joyce, David D. Hall, Richard D. Brown, and John B. Hench. American Antiquarian Society, 1983, pp. 2-47. 
---. World of Wonder, Days of Judgment. New York, Knopf, 1989.

Hall, Michael G. The Last American Puritan: The Life of Increase Mather. Middletown, Wesleyan UP, 1988.

Hambleton, Else L. Daughters of Eve: Pregnancy and Unwed Mothers in SeventeenthCentury Massachusetts. New York, Routledge, 2004.

Hanley, Richard. "New Jersey Charges Woman, 18, With Killing Baby Born at Prom." NYT. 25 June 1997. www.nytimes.com/1997/06/25/nyregion/new-jersey-chargeswoman-18-with-killing-baby-born-at-prom.html

Harding, Sandra. "What is Feminist Epistemology?" Who's Science? Who's Knowledge?: Thinking from Women's Lives. Cornel UP, 1991.

Harris, Sharon M. Executing Race: Early American Women's Narrative of Race, Society, and the Law. Ohio State UP, 2005.

---."Feminist Theories and Early American Studies.” Early American Literature, vol.34, no.1, 1999, pp. 86-93. JSTOR. Accessed 19 Jan 2014.

Heimert, Alan, and Andrew Delbanco, eds. The Puritans in America: A Narrative Anthology. Harvard UP, 1985.

Henigman, Laura. “'I would be a Witness against myself': Infanticide and Communion in Colonial New England.” Writing British Infanticide: Child-Murder, Gender, and Print, 1722-1859. Edited by Jennifer Thorn. Newark, U of Delaware Press, 2003.

Hodder, Alan D. “In the Gl asse of God's Word: Hooker's Pulpit Rhetoric and the Theater of Conversion." New England Quarterly, vol. 66, no. 1, 1993, pp. 67-109. JSTOR. Accessed 09 Dec 2015. 
Hoffer, Peter C. "Principled Discretion: Concealment, Conscience, and Chancellors." Yale Journal of Law and Humanities, vol.53, no. 3, 1991, pp. 53-81. HeinOnline. Accessed 19 Jan 2013.

Hoffer, Peter C., and N.E.H. Hull. Murdering Mothers: Infanticide in England and New England 1558-1803. New York UP, 1981.

Hull, N.E.H. Female Felons: Women and Serious Crime in Colonial Massachusetts. U of Illinois Press, 1987.

Ingebretsen, Ed. "Wigglesworth, Mather, Starr: Witch-hunts and General Wickedness in Public." Puritan Origins of American Sex. Edited by Tracy Fessenden et al. New York, Rutledge, 2001, pp. 21-40.

Irigaray, Luce. Speculum of the Other Woman. Cornell UP, 1985.

---. This Sex Which is Not One. Cornell UP, 1985.

Jackson, Mark. Infanticide: Historical Perspectives on Child Murder and Concealment, 1550-2000. Ashgate, 2002.

---. Newborn Child Murder: Women, Illegitimacy and the courts in eighteenth-century England. Manchester, Manchester UP, 1996.

Karlsen, Carol K. The Devil in the Shape of a Woman: Witchcraft in Colonial New England. New York, Norton, 1998.

Koehler, Lyle. A Search for Power: The "Weaker Sex" in Seventeenth-Century New England. U of Illinois Press, 1980.

Konig, David Thomas. Law and Society in Puritan Massachusetts Essex County 16291692. U of NC Press, 1979. 
Lasslett, Peter, Karla Oosterveen, and Richard M. Smith. Bastardy and its Comparative History. Harvard UP, 1980.

Lazenby, Walter. "Exhortation as Exorcism: Cotton Mather's Sermon to Murderers." Quarterly Journal of Speech, vol. 57, Feb 1971, pp. 50-56. Accessed 21 Oct. 2009.

Lévi-Strauss, Claude. "Linguistics and Anthropology (1958).” The Routledge Language and Cultural Theory Reader. Edited by Lucy Burke, Tony Crowley, and Alan Girvin. New York, Routledge, 2000. pp. 401-409.

Loring, Israel. The Duty and Interest of Young Persons. 1718. Early American Imprints, Series I: Evans. Accessed 09 December 2015.

Malcolmson, R.W. "Infanticide in the Eighteenth Century." Crime in England 15501800. Edited by J.S. Cockburn. Princeton UP, 1997. pp. 187-209.

Martin, Randall. Women, Murder, and Equity in Early Modern England. New York, Routledge, 2008.

Mather, Cotton. A Sorrowful Spectacle. 1715. Early American Imprints, Series I: Evans. Accessed 06 April 2006.

---. Pillars of salt. An history of some criminals executed in this land, for capital crimes. With some of their dying speeches; collected and published, for the warning of such as live in destructive courses of ungodliness. Whereto is added, for the better improvement of this history, a brief discourse about the dreadful justice of God, in punishing of sin, with sin. [Two lines from Deuteronomy]. 1698. Early American Imprints, Series I: Evans. Accessed 06 April 2006. 
---. Warnings from the dead. Or Solemn admonitions unto all people; but especially unto young persons to beware of such evils as would bring them to the dead. 1693. Early American Imprints, Series I: Evans. Accessed 06 April 2006.

Mather, Increase. The Folly of Sinning, Opened and Applied. 1699. Early American Imprints. Series I: Evans. Accessed 08 August 2008.

---. The Life and Death of that Reverend Man in God, Mr. Richard Mather. 1670. Early American Imprints. Series I: Evans. Accessed 12 November 2015.

McDonagh, Josephine. Child Murder and British Culture 1720-1900. London, Cambridge, 2003.

McGiffert, Michael, ed. Puritanism and the American Experience. Addison-Wesley, 1969.

Middlekauff, Robert. The Mathers: Three Generations of Puritan Intellectuals 15961728. U of California P, 1999.

Miller, Perry. "Errand Into the Wilderness." William and Mary Quarterly. vol. 10, no. 1, Jan 1953, pp. 3-32. JSTOR. Accessed 24 October 2016.

---“The Half-Way Covenant.” The New England Quarterly. vol. 6, no. 4, Dec 1933, pp. 676-715. JSTOR. Accessed 12 July 2015.

---The New England Mind: From Colony to Province. Harvard UP, 1967.

---“Preparations for Salvation' in Seventeenth-Century New England." Journal of the History of Ideas, vol. 4, no. 3, June 1943, pp. 253-286.

---, and Thomas J. Johnson. . The Puritans: A Sourcebook of Their Writings. 2 vols. New York, Harper \& Row, 1963. 
Minnick, Wayne C. "The New England Execution Sermons, 1639-1800." Speech Monographs, vol. 35, March 1968, pp. 77-89. Accessed 29 Oct. 2009.

Morgan, Edmund S. The Puritan Dilemma: The Story of John Winthrop. Boston, Little, Brown, and Co., 1958.

--- The Puritan Family: Religion and Domestic Relations in Seventeenth-Century New England. New York, Harper and Row, 1966.

---Visible Saints: The History of a Puritan Idea. NYU Press, 1963.

Mozley, J. F. John Foxe and His Book. New York, Octagon, 1970.

Murphy, Andrew R. Prodigal Nation. New York, Oxford UP, 2009.

Nagel, Thomas. "Concealment and Exposure." Philosophy and Public Affairs, vol. 27, no. 1, 1998, pp.3-30. JSTOR. Accessed 15 Mar 2018

Neuman, Meredith Marie. Jeremiah's Scribes: Creating Sermon Literature in Puritan New England. U Penn Press, 2013.

Nora, Pierre. "Between Memory and History: Les Lieux de Mémorie." Representations, vol. 26, Spring 1989, pp. 7-24. JSTOR. Accessed 5 Aug 2014.

Norton, Mary Beth. In the Devil's Snare: The Salem Witchcraft Crisis of 1692. New York, Vintage Books, 2002.

Pope, Robert G. The Half-Way Covenant: Church Membership in Puritan New England. Princeton UP, 1969.

Powers, Edwin. Crime and Punishment in Early Massachusetts 1620-1692. Beacon Press, Boston, 1966.

Reis, Elizabeth. Damned Women: Sinners and Witches in Puritan New England. Cornell UP, 1997. 
Ricouer, Paul. The Reality of the Historical Past. Marquette UP, 1984.

Rogers, John. Death the certain wages of sin to the impenitent: life the sure reward of grace to the penitent: together with the only way for youth to avoid the former, and attain the latter. Deliver'd in three lecture sermons; occasioned by the imprisonment, condemnation and execution, of a young woman, who was guilty of murdering her infant begotten in whoredom. To which is added, an account of her manner of life \&amp; death, in which the glory of free grace is displayed. By Mr. John Rogers, Pastor of the Church of Ipswich. 1701. Early American Imprints, Series I: Evans. Accessed 05 August 2006

Roth, Randolf. “Child Murder in New England.” Social Science History, vol.25, no.1, Spring 2001, pp. 101-147. Accessed 29 Oct. 2009.

Ruff, Julius R. Violence in Early Modern Europe. U of Cambridge Press, 2001.

Ryan, Kelly A. Regulating Passion: Sexuality and Patriarchal Rule in Massachusetts, 1700-1830. Oxford UP, 2014.

Saxton, Martha. Being Good: Women's Moral Values in Early America. New York, Hill and Wang, 2003.

Schorb, Jodi. “Hard-Hearted Women: Sentiment and the Scaffold.” Legacy: A Journal of American Women Writers, vol. 28, no.2, 2011, pp. 290-311. Project Muse. Accessed 21 Jan 2014.

--- "Uncleanliness is Next to Godliness: Sexuality, Salvation, and the Early American Woman's Execution Narrative.” Puritan Origins of American Sex: Religion, Sexuality, and National Identity in American Literature. Edited by Tracy 
Fessenden, Nicholas F. Radel, and Magdalena J. Zaborowska. New York, Routledge, 2001, pp. 72-92.

Sharpe, J.A. Crime in Early Modern England 1550-1750. London, Longman, 1984.

Shurtleff, William. The faith and prayer of a dying malefactor. A sermon preach'd December 27. 1739. On occasion of the execution of two criminals, namely Sarah Simpson and Penelope Kenny, and in the hearing of the former. By William Shurtleff, A.M. Pastor of a church in Portsmouth, New-Hampshire. To which is annex'd a brief narrative concerning the said criminals: and a preface by the Reverend Mr. Fitch. 1740. Early American Imprints, Series I: Evans. Accessed 05 August 2006.

Stenger, Mary Ann. "Feminist Philosophy of Religion." Methodology in Religious Studies. Edited by Arvind Sharma. SUNY Press, 2002, pp. 147-278.

“Student Charged in Infant's Death.” AP News, 4 April 2011, www.apnews.com/f3f4331bef48184f1386a95612e4d20f.

Symonds, Deborah A. Rev. of Writing British Infanticide: Child-Murder, Gender, and Print, 1722-1859, by ed. Jennifer Thorn. “Eighteenth-Century Fiction” vol.17. no.3, Apr. 2005, pp.558-562. Accessed 11 September 2006.

The Bible. King James Version, Biblegateway. www.biblegateway.com.

Ulrich, Laurel Thatcher. Good Wives: Image and Reality in the Lives of Women in Northern New England 1650-1750. New York, Vintage Books, 1980.

Vetere, Lisa M. “The Malefic Unconscious: Gender, Genre, and History in Early Antebellum Witchcraft Narrative.” Journal of Narrative Theory, vol.42, no. 2, Summer 2012, pp. 119-148. Project Muse. Accessed 21 Jan 2014. 
Von Rohr, John. "Covenant and Assurance in Early English Puritanism." Church History, vol.34, no. 2, June 1965, pp. 195-203. JSTOR. Accessed 17 Oct 2017.

Wall, Helena M. Fierce Communion: Family and Community in Early America. Harvard UP, 1990.

Williams, Daniel E. "'Behold a Tragic Scene Strangely Charged into a Theater of Mercy': The Structure and Significance of Criminal Conversion Narratives in Early New England." American Quarterly, vol.38, no. 5, 1986, pp. 827-847. JSTOR. Accessed 29 Oct 2009.

---. Pillars of Salt: An Anthology of Early American Criminal Narratives. Madison House, 1993.

Winthrop, John. Discourse on Arbitrary Government. www.constitution.org/bcp/winthlib.htm

---On Liberty 1645. www.constitution.org/bcp/winthlib.htm

Winthrop, Robert C. Life and Letters of John Winthrop. Boston, Ticknor and Fields, 1864

Wright, Louise W. "Sibling Rivalry: History and Memoir." Women's Review of Books, vol. 24, no. 4, July/August 2007, pp. 12-14. Accessed 5 Aug. 2014.

Wrightson, Keith. "Infanticide in earlier seventeenth-century England.” Local Population Studies, 1975, pp.10-22.

Woolard, Kathryn A. "Language Variation and Cultural Hegemony: Toward an Integration of Sociolinguistic and Social Theory." American Ethnologist, vol. 12, no. 4, Nov 1985, pp. 738-748. Accessed 11 Nov 2014. 


\title{
CURRICULUM VITAE
}

\author{
Jennifer S. White \\ jennifer.white1919@gmail.com
}

University of Louisville

1612 Richmond Drive

Stevenson Hall

Louisville, KY 40292

Louisville, KY 40205

(W) 502.852 .8160

(C) 502.435 .8345

\section{EDUCATION}

Ph.D., Humanities, University of Louisville, Louisville, KY, ABD

Dissertation: "Vile Transgressor of the Womb: Prosecution and

Persecution of Concealment in Puritan Massachusetts"

M.A., English, University of Louisville, Louisville, KY, 2010

Thesis: "Vile Transgressors of the Womb: Infanticide in Seventeenth and Eighteenth-Century New England"

B.A., English, State University of New York at Potsdam, Potsdam, NY 2004

Honors: $\quad$ Sigma Tau Delta English Honor Society

Awards: $\quad$ Faculty Favorite, student nominated award, 2012, 2013, 2014, University of Louisville

Graduate Assistantship, Office of the President, awarded consecutive academic years 2005- 20011, University of Louisville, Louisville, KY

Graduate Teaching Assistantship, awarded academic year 04-05, SUNY Potsdam

\section{TEACHING EXPERIENCE}

Adjunct Faculty, Women's and Gender Studies, University of Louisville, Louisville, KY (Summer 2009-Current)

WGS 201-On Campus and Fort Knox Campus-Women in American Culture: Examination of women's experiences in 19th and $20^{\text {th }}$ century America, focusing on issues pertaining to family, religion, economy, politics, law, race and class. (Course satisfies one of two cultural diversity requirements of the university)

WGS 303-Distance Ed-Humanities and Gender-Prerequisite: Sophomore Standing. This course is offered exclusively online through the Blackboard platform. Analysis of sex roles as embodied in classic works of philosophy, literature, history, drama, and art in ancient, medieval, 
modern, and contemporary times. (Course satisfies one of two cultural diversity requirements of the university)

WGS 325-Distance Ed-Women and Global Literature- An exploration of classic works of literature focusing on the construction of female gender norms to discuss the appropriation of female behavior, body image, and sexuality in the context of race and class. Areas covered in this course: $17^{\text {th }}$ and $18^{\text {th }}$ Century British Literature, $17^{\text {th }}$ and $18^{\text {th }}$ Century American Literature, Victorian Literature. (Course satisfies one of two cultural diversity requirements of the university)

WGS 326-Gender and Children's Literature-Examination of gender in British and North American literature for children/young adults from the late 19th century to the present with attention to the intersection of gender with common themes (e.g., heroic journey). Historical period: post-1900 British and American Literature.

WGS 390-Distance Ed-Women as Warriors: Prerequisite: Sophomore Standing: Examination and analysis of the use of "warrior" throughout western history as represented in art, literature, and drama to think critically about the way gender norms create barriers for women in historically male gender roles such. (Course satisfies one of two cultural diversity requirements of the university)

Adjunct Faculty, Humanities, University of Louisville, Louisville, KY (Fall 2013-Current)

HUM 331- Distance Ed-Humanities and Gender-Prerequisite: Sophomore Standing. This course is offered exclusively online through the Blackboard platform. Analysis of sex roles as embodied in classic works of philosophy, literature, history, drama, and art in ancient, medieval, modern, and contemporary times. (Course satisfies one of two cultural diversity requirements of the university)

HUM 390-Distance Ed-Women as Warriors- Prerequisite: Sophomore Standing: Examination and analysis of the use of "warrior" throughout western history as represented in art, literature, and drama to think critically about the way gender norms create barriers for women in historically male gender roles such.

Adjunct Faculty, English, University of Louisville, Louisville, KY (Fall 2013Current)

ENG 101-Freshman Composition-Course satisfies the composition requirement through various writing instruction and introduction to academic research and citation methods 
ENG 373-Distance Ed-Women and Global Literature- An exploration of classic works of literature focusing on the construction of female gender norms to discuss the appropriation of female behavior, body image, and sexuality in the context of race and class. Areas covered in this course: $17^{\text {th }}$ and $18^{\text {th }}$ Century British Literature, $17^{\text {th }}$ and $18^{\text {th }}$ Century American Literature, Victorian Literature. (Course satisfies one of two cultural diversity requirements of the university)

ENG 374-Gender and Children's Literature- Gender and Children's Literature-Examination of gender in British and North American literature for children/young adults from the late 19th century to the present with attention to the intersection of gender with common themes (e.g., heroic journey). Historical period: post-1900 British and American Literature.

Adjunct Faculty, Developmental English Studies, Kentucky Community and Technical College System (Spring 2013-2015)

ENC 091-Distance Ed-Second of two composition prerequisites to ENG 101 at the community college level. Course is offered completely online through the Blackboard platform

ENC 091-Hybrid Course-Second of two composition prerequisites to ENG 101 at the community college level. Course is offered through a combination of in-class meetings and online instruction through the Blackboard platform

International Faculty Team, Kentucky Institute for International Studies, Louisville, KY (Spring 2014-2016)

Selected as a faculty member for a teaching team in Italy (Summer 2015) as part of a consortium of Kentucky colleges and universities based out of Western Kentucky University. Responsibilities: team members are responsible for creating two unique courses to teach during the program; recruitment of students to the program through development of recruitment materials and presentations; ensure student success on site using 'Place as Text' pedagogy

Social Swat Team, University of Louisville, Louisville, KY (Spring 2013current)

Responsibilities: Work with the Director of Digital Media, Office of Communications and Marketing, to create energetic social media events to support student recruitment and the student experience; work collaboratively with other staff and faculty from various departments to create engaging materials for students using social media platforms (Twitter, Facebook, Tumblr, Instagram); participate in student engagement rallies; encourage collaboration and develop marketing ideas to increase involvement by specific academic units 


\section{ACADEMIC SUPPORT EXPERIENCE}

Coordinator, Strategic Partnerships, Office of the President, University of

Louisville, Louisville, KY (Jan 2011-Aug 2012)

Created as a central position for management and project development for strategic partnerships outlined by the president's goals in support of the executive director. Responsibilities: coordinated collaborative initiatives between university centers, offices, and senior administration focusing on program management; developed and maintained community partnerships; represented the university at national and regional education conferences as well as universities, local schools, and community events; worked directly with the Office of Communications and Marketing to develop marketing materials, establish and maintain a website; wrote and recruited for three graduate fellowship awards; developed and maintained social media strategies; leadership role in student services committees. Daily tasks included: office management with proficiency in MS Office, Adobe, PeopleSoft database; creating and leading presentations; maintaining website and social media presence; monitoring various collaborative programs across campus; directing 2 employees, 2 graduate assistants, and 4 work-study undergraduates; organizing 10-25 undergraduate student volunteers at campus-sponsored events.

Graduate Assistant, Office of the President, University of Louisville, Louisville, KY (Fall 2005-Spring 2011)

Responsibilities: Write, proof read, and maintain correspondence in various formats; compose and edit presidential correspondence, speeches, and internal communications; proof and edit publications for the Office of Communications and Marketing; research and design campus projects related to public space renovation; liaison between Office of the President and members of the numerous university (Board of Trustees, Board of Overseers, Alumni, Athletics, Committee on Academic Performance) and community boards; coordinated presidential boards and committee retreats; organize and staff committees delegated by the president addressing both faculty and student issues, represent the Office of the President at campus events. Daily tasks included: office management with proficiency in MS Office, Adobe, PeopleSoft database; creating and leading presentations; maintain president's personal correspondence; research projects.

Gubernatorial Appointee, Abraham Lincoln Bicentennial Commission, Gubernatorial Appointment, Frankfort, KY (Aug 2008-June 2010)

Responsibilities: Participate in a 32-member committee charged by the Governor of Kentucky to organize and oversee the celebratory events in Kentucky for the congressionally-mandated Abraham Bicentennial; create, collaborate, and coordinate historically-centered, educational events; 
represent the Commonwealth of Kentucky during events hosting international and national dignitaries

Peer Mentor, SUNY Potsdam, Potsdam, NY (Fall 2004)

Volunteered for peer mentoring for undergrads expressing interest in graduate programs; lead recruiting events for the graduate school; advised and supported undergrads with course selection and grad school applications; represented the university at on-campus and community events

Graduate Assistant, SUNY Potsdam, Potsdam, NY (Fall 2004-Spring 2005) Tutored students at SUNY Canton Writing Center; organized and facilitated appointments for students as required by professors; tutored ESL/EFL students with common writing problems; proofread and edited assignments for students in a variety of courses

\section{PROFESSIONAL STUDIES}

Delphi University Level II-Summer 2013-University of Louisville Designed to give faculty advanced instruction for dynamic online classroom design. Course focused on using Wikis, blogs, and digital media to increase student involvement through creating a vibrant, engaging online classroom.

What's New In Blackboard-Spring 2012-University of Louisville Focused on the new technology and changes made in the Blackboard platform update.

Delphi University Level I-Summer 2012-University of Louisville Designed to give faculty the tools and principles to create effective, interactive and stimulating online courses. Instruction focused on creating an online course and the skills required to conduct a vibrant studentcentered online classroom. Specific instruction: course objectives based syllabus design; online assessment tools; Blackboard technology; best practices for online teaching and learning.

\section{ACADEMIC CONFERENCES}

"Rebekah Chamblit: A Vile Transgressor of the Womb; Finding a Voice in a System that Silenced" New Directions in the Humanities, thehumanities.com, Budapest, Hungary, June 2013-Graduate Scholar Award

"The MILF Phenomenon and Mommy Porn: Motherhood as Eroticized Heterosexual Beauty and Patriarchal Tool" Pop Culture Association/American Culture Association National Conference 2013, pcaaca.org, Washington D.C., March 2013

"Vile Transgressor of the Womb: Reading Rebekah Chamblit's Silence" Evil, Women and the Feminine Conference 2011, Interdisciplinary.net, Warsaw, Poland, May 2011 